\title{
Implementation of Telemental Health Services Before COVID-19: Rapid Umbrella Review of Systematic Reviews
}

Phoebe Barnett ${ }^{1,2}$, MSc; Lucy Goulding ${ }^{3}$, PhD; Cecilia Casetta ${ }^{4}$, MD; Harriet Jordan ${ }^{4,5}$, MSc; Luke Sheridan-Rains ${ }^{2}$, $\mathrm{PhD}$; Thomas Steare ${ }^{2}, \mathrm{MSc}$; Julie Williams ${ }^{6}, \mathrm{PhD}$; Lisa Wood ${ }^{7}, \mathrm{PhD}$; Fiona Gaughran ${ }^{4,5^{*}}, \mathrm{MD}$; Sonia Johnson ${ }^{2,8^{*}}$, $\mathrm{DM}$

${ }^{1}$ Centre for Outcomes Research and Effectiveness, Division of Psychology and Language Sciences, University College London, London, United Kingdom

${ }^{2}$ NIHR Mental Health Policy Research Unit, Division of Psychiatry, University College London, London, United Kingdom

${ }^{3}$ King's Improvement Science, Centre for Implementation Science, King's College London, London, United Kingdom

${ }^{4}$ NIHR Applied Research Collaboration, King's College London, London, United Kingdom

${ }^{5}$ Institute of Psychiatry, Psychology and Neuroscience, King's College London and South London and Maudsley NHS Trust, London, United Kingdom

${ }^{6}$ Centre for Implementation Science, Health Service and Population Research Department, King's College London, London, United Kingdom

${ }^{7}$ Division of Psychiatry, University College London, London, United Kingdom

${ }^{8}$ Camden and Islington NHS Foundation Trust, London, United Kingdom

*these authors contributed equally

\section{Corresponding Author:}

Phoebe Barnett, MSc

Centre for Outcomes Research and Effectiveness

Division of Psychology and Language Sciences

University College London

1-19 Torrington Place

London, WC1E 7HB

United Kingdom

Phone: 4402076126143

Email: phoebe.barnett@ucl.ac.uk

\section{Abstract}

Background: Telemental health care has been rapidly adopted for maintaining services during the COVID-19 pandemic, and a substantial interest is now being devoted in its future role. Service planning and policy making for recovery from the pandemic and beyond should draw on both COVID-19 experiences and the substantial research evidence accumulated before this pandemic.

Objective: We aim to conduct an umbrella review of systematic reviews available on the literature and evidence-based guidance on telemental health, including both qualitative and quantitative literature.

Methods: Three databases were searched between January 2010 and August 2020 for systematic reviews meeting the predefined criteria. The retrieved reviews were independently screened, and those meeting the inclusion criteria were synthesized and assessed for risk of bias. Narrative synthesis was used to report these findings.

Results: In total, 19 systematic reviews met the inclusion criteria. A total of 15 reviews examined clinical effectiveness, 8 reported on the aspects of telemental health implementation, 10 reported on acceptability to service users and clinicians, 2 reported on cost-effectiveness, and 1 reported on guidance. Most reviews were assessed to be of low quality. The findings suggested that video-based communication could be as effective and acceptable as face-to-face formats, at least in the short term. Evidence on the extent of digital exclusion and how it can be overcome and that on some significant contexts, such as children and young people's services and inpatient settings, was found to be lacking.

Conclusions: This umbrella review suggests that telemental health has the potential to be an effective and acceptable form of service delivery. However, we found limited evidence on the impact of its large-scale implementation across catchment areas. Combining previous evidence and COVID-19 experiences may allow realistic planning for the future implementation of telemental health. 


\section{KEYWORDS}

umbrella review; remote; telemental health; telepsychiatry; video-based therapy; COVID-19; remote therapy; review; mental health; therapy; eHealth; telemedicine; mobile phone

\section{Introduction}

\section{Background}

The use of technologies such as phone or video calls between mental health professionals and other mental health professionals, patients, service users, family members, or carers to deliver mental health care (telemental health) has become an essential tool in recent months; importantly, it has taken a central role internationally in maintaining mental health services during the COVID-19 pandemic [1]. Policy makers and mental health professionals, along with mental health service users, now express interest in continuing some use of these technologies long term, even in the absence of pandemic-related social distancing requirements [1-3]. The potential benefits of remote technologies extend beyond adaptation to government social distancing guidelines, allowing the efficiency and flexibility of mental health services to be maximized. The mobilization of telemental health during the pandemic has happened largely ad hoc, thereby achieving remarkably rapid but highly variable implementation. This emergency response has mostly occurred without systematic references to the literature. To plan the effective and acceptable deployment of telemental health beyond the pandemic, it is crucial that we now review all the relevant evidence regarding potential impacts, challenges, and outcomes of widespread remote technology utilization and identify the key mechanisms for its acceptable integration into routine care [4].

Telemental health offers a number of potential benefits that generate a significant interest among service providers not only during the pandemic but also in the long term. For service users across a range of populations, settings, and conditions [5], potential benefits include convenience and improved accessibility, particularly where issues such as physical mobility difficulties, anxiety, or paranoia impede a face-to-face contact [1]. Potential advantages for staff include reduced environmental impact, greater convenience with opportunities for working at home, and ease of communication within and between mental health teams [2]. Although some have argued that problems with building rapport [6] along with privacy and safety concerns may hinder the implementation of remote care, service users have been found to report such apprehensions less than clinicians [7]. Several studies have also suggested that telemental health may be more cost-effective than face-to-face delivery [7].

Despite potential benefits and a substantial body of relevant research, the delivery of remote working remained very limited in most countries before the pandemic with substantial implementation barriers [8], along with the potential for inequalities to be exacerbated. Digital exclusion is an important concern for service users who lack the necessary skills, space, equipment, and monetary resources to access web-based treatment. This is more marked in marginalized groups such as people from BAME (Black, Asian, and minority ethnic) and low socioeconomic status backgrounds [9]. Further risks include the loss of privacy and deterioration in therapeutic relationships [1,10-12]. Staff participation is also impeded by technological and environmental difficulties, and they express reservations regarding the quality of assessments, deterioration of therapeutic relationships, and limitations in the extent to which there is a focus on physical as well as mental health $[8,11,12]$.

\section{Objectives}

Therefore, the potential benefits and disadvantages of telemental health are finely balanced. Risks of longer-term rollout of telemental health without close attention to intended and unintended consequences include the digital exclusion of some of those already most disadvantaged and decline in the quality of care and, potentially, of outcomes. One source with the potential to inform policy makers and service planners in their future telemental health strategies is the substantial body of research studies published before the pandemic. This paper therefore aims to provide a rapid summary of the existing literature on the effectiveness, cost-effectiveness, barriers and facilitators for implementation, acceptability, and reach of remote interventions for the assessment and treatment of mental health problems. Our objective is to identify, appraise, and synthesize the systematic reviews of literature and guidance on telemental health, including qualitative and quantitative outcomes using the umbrella review or review of reviews methodology. Umbrella reviews are useful in summarizing a broad evidence base to inform policy [13]. It is hoped that the results will help illuminate the benefits and remaining challenges while implementing telehealth technologies during the remainder of the pandemic and in the perhaps permanently changed reality that follows.

\section{Methods}

\section{Overview}

A rapid umbrella review was conducted guided by the World Health Organization practical guide for Rapid Reviews to Strengthen Health Policy and Systems [14] and adhering to PRISMA (Preferred Reporting Items for Systematic Reviews and Meta-Analyses) guidelines [15] and umbrella review guidance [16]. In line with the agreed rapid review methodology, this review aims to provide a timely but robust answer to the research question by accelerating some aspects of the systematic review process while maintaining transparency and protocol-driven decision making throughout [14]. The protocol was prospectively registered on PROSPERO (CRD42020208085).

\section{Search Strategy and Selection Criteria}

\section{Overview}

The search strategy implemented a combination of keywords and subject heading searches across PsycINFO (01/01/2010-26/08/2020), PubMed (01/01/2010-26/08/2020), and the Cochrane Database of Systematic Reviews 
(01/01/2010-26/08/2020). Searches combined terms for systematic reviews, mental health disorders, and telemental health. The full search strategy is available in Multimedia Appendix 1. We included systematic reviews that met the following criteria.

\section{Population}

Staff working within the field of mental health, people receiving mental health care or with mental health diagnoses, family members, or carers of people receiving mental health care were included. In line with our focus on people whose conditions tend to make them eligible for telemental health care, we also included people with dementia, neurodevelopmental disorders, and addiction but excluded people with primary sleep disorders, unless combined with other mental health problems.

\section{Interventions}

Any form of spoken or written communication conducted between mental health professionals and patients, service users, family members, carers, or other mental health professionals using either the internet or the telephone were included. We excluded the reviews of digital interventions where the primary aim of the technology was not to facilitate direct therapeutic contact with a mental health professional; thus, for example, we excluded apps and websites delivering assessment or treatment in a digital format.

\section{Outcomes}

Reviews reporting at least one of the following: implementation outcomes (outcomes relating to the process of care, adherence to intended models, uptake and coverage, and barriers and facilitators to implementation), acceptability outcomes (including staff and service user satisfaction, and experiences of the therapeutic relationship and communication), clinical effectiveness, cost-effectiveness, or evidence-based guidance for telemental health were included. Qualitative and quantitative data were analyzed.

\section{Design}

Systematic reviews with or without meta-analyses, realist reviews, and qualitative meta-syntheses were included. We considered reviews to be of sufficient quality for inclusion if they searched at least three databases based on recommendations by Cochrane and the Assessment of Multiple Systematic Reviews (AMSTAR) [17], meaning that at least two databases plus subject-specific databases were searched. In line with recommendations for conducting systematic reviews for quantitative data [15], quantitative reviews were also required to include appraisal of the quality of included studies.
Owing to the rapid nature of the review, we limited our search to reviews published since January 2010 and those available in the English language. This was a pragmatic decision because studies published before 2010 would still be picked up within systematic reviews.

A total of 3 reviewers (PB, LG, and CC) double screened $10 \%$ of titles and abstracts, and disagreements were discussed until consensus was reached. The remaining titles were independently screened, and studies not meeting the inclusion criteria were excluded. Full-text articles were subsequently reviewed by 5 reviewers (PB, TS, LG, CC, and LW). A selection of full texts was double checked to ensure consistency, and any reviews that did not facilitate a straightforward inclusion or exclusion decision were discussed with the wider review group.

\section{Data Extraction}

A total of 7 reviewers (LG, CC, PB, TS, LSR, JW, and HIJ) extracted data from the included reviews using a Microsoft Excel-based form. In total, $10 \%$ of extractions were double checked by a second reviewer, and inconsistencies were discussed and corrected. The extracted data included citation details, objectives, type of review, participant details (including gender, ethnicity, age, and mental health diagnosis accompanied by staff details where relevant), types of telemental health intervention reviewed, setting and context (mental health service, community, inpatient or residential, or primary mental health care service), number of databases sourced and searched, date range of database searching, the publication date range of studies included in the review informing each outcome of interest, number of included studies, types of studies and country of origin of studies included, instrument used to appraise the primary studies and the rating of their quality; reported clinical, cost-effectiveness, and implementation outcomes; method of synthesis or analysis employed to synthesize the evidence; and conclusions of the review authors.

\section{Quality Assessment}

The quality of each included systematic review was assessed using the AMSTAR 2 checklist [17]. This is a revised version of the original AMSTAR checklist [18], which is a validated measure of systematic review quality [19]. The checklist was used to give each review an overall rating of quality ranging from high ( 0 or 1 noncritical weakness: providing an accurate and comprehensive summary of the results of the available studies that address the question of interest) to critically low (more than 1 critical flaw with or without noncritical weaknesses: the review should not be relied upon to provide an accurate and comprehensive summary of the available studies) [17]. The study quality was assessed along with data extraction. Table 1 presents the quality ratings. 
Table 1. Study characteristics.

\begin{tabular}{|c|c|c|c|c|c|c|c|c|c|c|c|}
\hline Study & $\begin{array}{l}\text { Intervention type } \\
\text { (number of stud- } \\
\text { ies) }\end{array}$ & $\begin{array}{l}\text { Comparator } \\
\text { (number of } \\
\text { studies) }\end{array}$ & $\begin{array}{l}\text { Search } \\
\text { dates }\end{array}$ & $\begin{array}{l}\text { Number } \\
\text { of stud- } \\
\text { ies in- } \\
\text { cluded }\end{array}$ & $\begin{array}{l}\text { Study de- } \\
\text { signs } \\
\text { (number } \\
\text { of stud- } \\
\text { ies) }\end{array}$ & $\begin{array}{l}\text { Patients } \\
\text { includ- } \\
\text { ed, n }(\% \\
\text { female })\end{array}$ & $\begin{array}{l}\begin{array}{l}\text { Diagnoses } \\
\text { (number of } \\
\text { studies) }\end{array} \\
\end{array}$ & $\begin{array}{l}\text { Popula- } \\
\text { tion age } \\
\text { in years, } \\
\text { mean } \\
\text { (range) }\end{array}$ & $\begin{array}{l}\text { Ethnic- } \\
\text { ity, n } \\
(\%)\end{array}$ & $\begin{array}{l}\text { Countries cov- } \\
\text { ered (number } \\
\text { of studies) }\end{array}$ & $\begin{array}{l}\text { Quality } \\
\text { ap- } \\
\text { praisal } \\
\text { rating } \\
\text { (AM- } \\
\text { STAR } \\
\left.2^{\text {a }}\right)\end{array}$ \\
\hline $\begin{array}{l}\text { Hareri- } \\
\text { mana et } \\
\text { al (2019) } \\
{[20]}\end{array}$ & $\begin{array}{l}\text { Mobile apps } \\
\left(\mathrm{NR}^{\mathrm{b}}\right) \text {; smart } \\
\text { technologies } \\
(\mathrm{NR}) \text {; teleconfer- } \\
\text { encing systems } \\
\text { (NR); internet- } \\
\text { based therapies } \\
\text { (NR); Skype } \\
\text { (videoconferenc- } \\
\text { ing) calls (NR) }\end{array}$ & $\begin{array}{l}\text { Waiting list } \\
\text { or TAU } \\
(\mathrm{NR}) \text {; no } \\
\text { comparator } \\
\text { (NR) }\end{array}$ & $\begin{array}{l}1946- \\
2017\end{array}$ & 9 & $\begin{array}{l}\begin{array}{l}\text { Pilot } \\
\mathrm{RCT}^{\mathrm{d}} \\
(\mathrm{n}=2) ;\end{array} \\
\mathrm{RCT} \\
(\mathrm{n}=2) ; \\
\text { program } \\
\text { case anal- } \\
\text { ysis } \\
(\mathrm{n}=1) ; \\
\text { quasiex- } \\
\text { perimen- } \\
\text { tal study } \\
(\mathrm{n}=1) ; \\
\text { prospec- } \\
\text { tive de- } \\
\text { sign } \\
(\mathrm{n}=1) ; \\
\text { cross-sec- } \\
\text { tional sur- } \\
\text { vey } \\
(\mathrm{n}=1) ; \\
\text { case } \\
\text { study } \\
(\mathrm{n}=1)\end{array}$ & $\begin{array}{l}2032 \\
\text { (NR) }\end{array}$ & $\begin{array}{l}\text { Depression } \\
\text { or self-re- } \\
\text { ported de- } \\
\text { pressive } \\
\text { symptoms } \\
(\mathrm{n}=9)\end{array}$ & $>65$ (NR) & NR & $\begin{array}{l}\text { United States } \\
(n=5) ; \text { Aus- } \\
\text { tralia }(n=1) ; \\
\text { Canada }(n=1) ; \\
\text { China }(n=1) ; \\
\text { The Nether- } \\
\text { lands }(n=1)\end{array}$ & Low \\
\hline $\begin{array}{l}\text { Dorstyn } \\
\text { et al } \\
(2013) \\
{[21]}\end{array}$ & $\begin{array}{l}\text { Telecounseling, } \\
\text { that is, telephone, } \\
\text { videophone, and } \\
\text { computer (NR) or } \\
\text { web-based digital } \\
\text { media, that is, } \\
\text { email, audio-on- } \\
\text { ly, or audio-video } \\
\text { communication } \\
\text { via the internet } \\
\text { (NR) }\end{array}$ & $\begin{array}{l}\text { TAU }(\mathrm{n}=3) \text {; } \\
\text { face-to-face } \\
(\mathrm{n}=1) \text {; mini- } \\
\text { mal support } \\
\text { or waitlist } \\
(\mathrm{n}=2) \text {; no } \\
\text { comparator } \\
(\mathrm{n}=2)\end{array}$ & $\begin{array}{l}1970- \\
2013\end{array}$ & $\begin{array}{l}9 \text { (8 dif- } \\
\text { ferent } \\
\text { sam- } \\
\text { ples })\end{array}$ & $\begin{array}{l}\text { RCT } \\
(\mathrm{n}=7) ; \\
\text { single } \\
\text { arm } \\
(\mathrm{n}=1) ; \\
\text { nonran- } \\
\text { domized } \\
\text { con- } \\
\text { trolled tri- } \\
\text { al }(\mathrm{n}=1)\end{array}$ & $\begin{array}{l}498 \\
(\mathrm{n}=66)\end{array}$ & $\begin{array}{l}\text { Depression } \\
\text { or psychi- } \\
\text { atric comor- } \\
\text { bidities } \\
\text { with depres- } \\
\text { sion symp- } \\
\text { toms }(n=9)\end{array}$ & $54(\mathrm{NR})$ & $\begin{array}{l}\text { His- } \\
\text { panic, } \\
243 \\
(52) ; \\
\text { Lati- } \\
\text { no, } \\
139 \\
(30) ; \\
\text { Asian, } \\
105 \\
(21) ; \\
\text { African } \\
\text { Ameri- } \\
\text { can, } \\
11(2)\end{array}$ & $\begin{array}{l}\text { United States } \\
(\mathrm{n}=6) \text {; Canada } \\
(\mathrm{n}=1) \text {; Aus- } \\
\text { tralia }(\mathrm{n}=1)\end{array}$ & $\begin{array}{l}\text { Critical- } \\
\text { ly low }\end{array}$ \\
\hline
\end{tabular}




\begin{tabular}{|c|c|c|c|c|c|c|c|c|c|c|c|}
\hline Study & $\begin{array}{l}\text { Intervention type } \\
\text { (number of stud- } \\
\text { ies) }\end{array}$ & $\begin{array}{l}\text { Comparator } \\
\text { (number of } \\
\text { studies) }\end{array}$ & $\begin{array}{l}\text { Search } \\
\text { dates }\end{array}$ & $\begin{array}{l}\text { Number } \\
\text { of stud- } \\
\text { ies in- } \\
\text { cluded }\end{array}$ & $\begin{array}{l}\text { Study de- } \\
\text { signs } \\
\text { (number } \\
\text { of stud- } \\
\text { ies) }\end{array}$ & $\begin{array}{l}\text { Patients } \\
\text { includ- } \\
\text { ed, n (\% } \\
\text { female) }\end{array}$ & $\begin{array}{l}\text { Diagnoses } \\
\text { (number of } \\
\text { studies) }\end{array}$ & $\begin{array}{l}\text { Popula- } \\
\text { tion age } \\
\text { in years, } \\
\text { mean } \\
\text { (range) }\end{array}$ & $\begin{array}{l}\text { Ethnic- } \\
\text { ity, n } \\
(\%)\end{array}$ & $\begin{array}{l}\text { Countries cov- } \\
\text { ered (number } \\
\text { of studies) }\end{array}$ & $\begin{array}{l}\text { Quality } \\
\text { ap- } \\
\text { praisal } \\
\text { rating } \\
\text { (AM- } \\
\text { STAR } \\
2^{\mathrm{a}} \text { ) }\end{array}$ \\
\hline $\begin{array}{l}\text { Berryhill } \\
\text { et al } \\
(2019 a) \\
{[22]}\end{array}$ & $\begin{array}{l}\text { Video-based } \\
\text { CBT }^{\mathrm{e}}(\mathrm{n}=12) \text {; } \\
\text { video-based be- } \\
\text { havioral activa- } \\
\text { tion }(\mathrm{n}=5) \text {; video- } \\
\text { based acceptance } \\
\text { and behavioral } \\
\text { therapy ( } \mathrm{n}=1) ; \\
\text { video-based expo- } \\
\text { sure ( } \mathrm{n}=3) ; \\
\text { video-based } \\
\text { metacognitive } \\
\text { therapy ( } \mathrm{n}=1) ; \\
\text { video-based } \\
\text { problem-solving } \\
\text { therapy ( } \mathrm{n}=2) ; \\
\text { video-based thera- } \\
\text { py in multiple } \\
\text { modalities ( } \mathrm{n}=9 \text { ) }\end{array}$ & $\begin{array}{l}\text { Face-to-face } \\
\text { psychothera- } \\
\text { py }(n=16) ; \\
\text { face-to-face } \\
\text { or telephone } \\
(n=2) ; \text { no } \\
\text { control } \\
(n=15)\end{array}$ & $\begin{array}{l}1991- \\
2017\end{array}$ & 33 & $\begin{array}{l}\text { RCT } \\
(\mathrm{n}=14) ; \\
\text { quasiex- } \\
\text { perimen- } \\
\text { tal }(\mathrm{n}=4) ; \\
\text { single co- } \\
\text { hort } \\
\text { study-be- } \\
\text { fore and } \\
\text { after } \\
\text { (n=9); } \\
\text { case } \\
\text { study } \\
\text { (n=4); } \\
\text { multiple } \\
\text { baseline } \\
\text { design } \\
\text { (n=1); } \\
\text { single } \\
\text { case inter- } \\
\text { rupted } \\
\text { time se- } \\
\text { ries ( } n=1)\end{array}$ & NR & $\begin{array}{l}\text { Depression } \\
(n=9) ; \\
\text { PTSD }^{\mathrm{f}} \\
(\mathrm{n}=12) \text {; de- } \\
\text { pression } \\
\text { with comor- } \\
\text { bid anxiety } \\
\text { or PTSD } \\
(\mathrm{n}=12)\end{array}$ & $\begin{array}{l}\text { NR } \\
(10.3- \\
80.4)\end{array}$ & NR & NR & $\begin{array}{l}\text { Critical- } \\
\text { ly low }\end{array}$ \\
\hline $\begin{array}{l}\text { Berryhill } \\
\text { et al } \\
(2019 b) \\
{[23]}\end{array}$ & $\begin{array}{l}\text { Video-based } \\
\text { CBT ( } \mathrm{n}=12) \text {; } \\
\text { video-based be- } \\
\text { havioral activa- } \\
\text { tion ( } \mathrm{n}=3 \text { ); video- } \\
\text { based ACT }^{\mathrm{g}} \\
(\mathrm{n}=1) \text {; video- } \\
\text { based exposure } \\
\text { therapy ( } \mathrm{n}=2) ; \\
\text { video-based } \\
\text { problem-solving } \\
\text { therapy ( } \mathrm{n}=1) ; \\
\text { video-based } \\
\text { metacognitive } \\
\text { therapy ( } \mathrm{n}=1) ; \\
\text { multiple modality } \\
(\mathrm{n}=1)\end{array}$ & $\begin{array}{l}\text { Face-to-face } \\
\text { psychothera- } \\
\text { py }(n=20) ; \\
\text { no control } \\
(n=1)\end{array}$ & $\begin{array}{l}1991- \\
2017\end{array}$ & 21 & $\begin{array}{l}\text { RCT } \\
(n=6) ; \\
\text { quasiex- } \\
\text { perimen- } \\
\text { tal }(n=4) ; \\
\text { uncon- } \\
\text { trolled } \\
(n=11)\end{array}$ & $\mathrm{NR}$ & $\begin{array}{l}\begin{array}{l}\text { Depression } \\
(\mathrm{n}=2) ;\end{array} \\
\text { PTSD } \\
(\mathrm{n}=7) \text {; anxi- } \\
\text { ety disor- } \\
\text { der (ie, } \\
\text { PD }^{\mathrm{h}} \text {, } \\
\mathrm{GAD}^{\mathrm{i}} \text {, and } \\
\text { social pho- } \\
\text { bia; } \mathrm{n}=5) \text {; } \\
\text { depression } \\
\text { or mood } \\
\text { disorder } \\
(\mathrm{n}=7)\end{array}$ & $\begin{array}{l}\text { NR (8- } \\
62)\end{array}$ & NR & $\begin{array}{l}\text { United States } \\
(\mathrm{n}=10) ; \text { Aus- } \\
\text { tralia }(\mathrm{n}=6) ; \\
\text { Canada }(\mathrm{n}=5)\end{array}$ & $\begin{array}{l}\text { Critical- } \\
\text { ly low }\end{array}$ \\
\hline $\begin{array}{l}\text { Bolton } \\
\text { and } \\
\text { Dorstyn } \\
(2015) \\
{[24]}\end{array}$ & $\begin{array}{l}\text { Internet-based } \\
\text { CBT with thera- } \\
\text { pist support via } \\
\text { telephone calls, } \\
\text { introductory face- } \\
\text { to-face meetings, } \\
\text { or emails }(n=6) \text {; } \\
\text { video-based CBT } \\
(n=5)\end{array}$ & $\begin{array}{l}\text { Face-to-face } \\
(n=5) ; \text { sup- } \\
\text { portive coun- } \\
\text { seling }(n=1) \text {; } \\
\text { waitlist } \\
(n=1) ; \text { no } \\
\text { comparator } \\
(n=4)\end{array}$ & $\begin{array}{l}1970- \\
2014\end{array}$ & 11 & $\begin{array}{l}\begin{array}{l}\text { RCT } \\
(n=4) ;\end{array} \\
\text { nonran- } \\
\text { domized } \\
(n=7)\end{array}$ & $\begin{array}{l}472 \\
(\mathrm{NR})\end{array}$ & $\begin{array}{l}\text { PTSD } \\
(n=11)\end{array}$ & $\begin{array}{l}40(18- \\
68)\end{array}$ & NR & $\begin{array}{l}\text { United States } \\
(\mathrm{n}=6) ; \text { Aus- } \\
\text { tralia }(\mathrm{n}=3) ; \\
\text { Canada }(\mathrm{n}=1) \text {; } \\
\text { United King- } \\
\text { dom }(\mathrm{n}=1)\end{array}$ & $\begin{array}{l}\text { Critical- } \\
\text { ly low }\end{array}$ \\
\hline
\end{tabular}




\begin{tabular}{|c|c|c|c|c|c|c|c|c|c|c|c|}
\hline Study & $\begin{array}{l}\text { Intervention type } \\
\text { (number of stud- } \\
\text { ies) }\end{array}$ & $\begin{array}{l}\text { Comparator } \\
\text { (number of } \\
\text { studies) }\end{array}$ & $\begin{array}{l}\text { Search } \\
\text { dates }\end{array}$ & $\begin{array}{l}\text { Number } \\
\text { of stud- } \\
\text { ies in- } \\
\text { cluded }\end{array}$ & $\begin{array}{l}\text { Study de- } \\
\text { signs } \\
\text { (number } \\
\text { of stud- } \\
\text { ies) }\end{array}$ & $\begin{array}{l}\text { Patients } \\
\text { includ- } \\
\text { ed, n (\% } \\
\text { female) }\end{array}$ & $\begin{array}{l}\text { Diagnoses } \\
\text { (number of } \\
\text { studies) }\end{array}$ & $\begin{array}{l}\text { Popula- } \\
\text { tion age } \\
\text { in years, } \\
\text { mean } \\
\text { (range) }\end{array}$ & $\begin{array}{l}\text { Ethnic- } \\
\text { ity, n } \\
(\%)\end{array}$ & $\begin{array}{l}\text { Countries cov- } \\
\text { ered (number } \\
\text { of studies) }\end{array}$ & $\begin{array}{l}\text { Quality } \\
\text { ap- } \\
\text { praisal } \\
\text { rating } \\
\text { (AM- } \\
\text { STAR } \\
2^{\mathrm{a}} \text { ) }\end{array}$ \\
\hline $\begin{array}{l}\text { Chris- } \\
\text { tensen et } \\
\text { al (2019) } \\
{[25]}\end{array}$ & $\begin{array}{l}\text { Video consulta- } \\
\text { tions and telepsy- } \\
\text { chiatry }(n=21)\end{array}$ & $\begin{array}{l}\text { Face-to-face } \\
(n=11) ; \text { no } \\
\text { control } \\
(n=10)\end{array}$ & $\begin{array}{l}2000- \\
2017\end{array}$ & 21 & $\begin{array}{l}\text { RCT } \\
(\mathrm{n}=7) ; \\
\text { surveys } \\
(\mathrm{n}=3) \text {; in- } \\
\text { terven- } \\
\text { tion study } \\
\text { ( } \mathrm{n}=6) ; \\
\text { evalua- } \\
\text { tion using } \\
\text { qualita- } \\
\text { tive and } \\
\text { quantita- } \\
\text { tive meth- } \\
\text { ods } \\
\text { (n=1); } \\
\text { qualita- } \\
\text { tive stud- } \\
\text { ies (n=4) }\end{array}$ & $\begin{array}{l}2525 \\
(\mathrm{NR})\end{array}$ & $\begin{array}{l}\text { Depression } \\
(n=6) \text {; vari- } \\
\text { ous diag- } \\
\text { noses } \\
(n=15)\end{array}$ & NR & NR & $\begin{array}{l}\text { United States } \\
(\mathrm{n}=12) ; \text { Cana- } \\
\text { da }(\mathrm{n}=5) ; \\
\text { Spain }(\mathrm{n}=1) ; \\
\text { Australia } \\
(\mathrm{n}=1) ; \text { Hong } \\
\text { Kong }(\mathrm{n}=1) ; \\
\text { Germany } \\
(\mathrm{n}=1)\end{array}$ & Low \\
\hline $\begin{array}{l}\text { Coughtrey } \\
\text { and Pis- } \\
\text { trang } \\
(2018) \\
{[26]}\end{array}$ & $\begin{array}{l}\operatorname{CBT}(n=12) ; \\
\operatorname{ERPT}^{\mathrm{j}}(\mathrm{n}=1) \text {; be- } \\
\text { havioral therapy } \\
(\mathrm{n}=1)\end{array}$ & $\begin{array}{l}\text { Face-to-face } \\
\text { exposure re- } \\
\text { sponse thera- } \\
\text { py }(n=1) ; \\
\text { telephone } \\
\text { emotion-fo- } \\
\text { cused thera- } \\
\text { py }(n=1) ; \\
\text { TAU }(n=5) \text {; } \\
\text { waitlist } \\
(n=3) ; \text { no } \\
\text { comparator } \\
(n=4)\end{array}$ & $\begin{array}{l}1991- \\
2016\end{array}$ & 14 & $\begin{array}{l}\text { RCT } \\
\text { (n=9); un- } \\
\text { con- } \\
\text { trolled de- } \\
\text { sign } \\
(\mathrm{n}=3) ; \\
\text { quasiex- } \\
\text { perimen- } \\
\text { tal }(\mathrm{n}=2)\end{array}$ & $\begin{array}{l}750 \\
(\mathrm{NR})\end{array}$ & $\begin{array}{l}\text { Depression } \\
(\mathrm{n}=10 ; 5 \\
\text { with physi- } \\
\text { cal comor- } \\
\text { bidities); } \\
\text { OCD }^{\mathrm{k}} \\
(\mathrm{n}=2) \text {; anxi- } \\
\text { ety disor- } \\
\text { ders }(\mathrm{n}=2)\end{array}$ & $\begin{array}{l}\text { NR }(32- \\
66)\end{array}$ & NR & $\begin{array}{l}\text { United States } \\
(n=11) ; \text { Unit- } \\
\text { ed Kingdom } \\
(n=2) ; \text { Canada } \\
(n=1)\end{array}$ & Low \\
\hline $\begin{array}{l}\text { Drag et al } \\
(2016) \\
{[27]}\end{array}$ & $\begin{array}{l}\text { Videoconference } \\
(\mathrm{n}=24)\end{array}$ & $\begin{array}{l}\text { Face-to-face } \\
(n=23) ; \text { no } \\
\text { comparator } \\
(n=1)\end{array}$ & $\begin{array}{l}2000- \\
2015\end{array}$ & 26 & $\begin{array}{l}\text { RCT } \\
(n=26)\end{array}$ & $\begin{array}{l}\text { Analy- } \\
\text { sis of as- } \\
\text { sess- } \\
\text { ment, } \\
765 \\
\text { (NR); } \\
\text { analysis } \\
\text { of effica- } \\
\text { cy } 2097 \\
\text { (NR) }\end{array}$ & $\begin{array}{l}\text { Analysis of } \\
\text { assess- } \\
\text { ment: multi- } \\
\text { ple diag- } \\
\text { noses } \\
\text { (n=6); } \\
\text { Alzheimer } \\
\text { disease } \\
\text { (n=2); } \\
\text { schizophre- } \\
\text { nia (n=3); } \\
\text { autism } \\
\text { (n=1); anal- } \\
\text { ysis of effi- } \\
\text { cacy: multi- } \\
\text { ple diag- } \\
\text { noses } \\
(n=2) ; \\
\text { PTSD } \\
\text { (n=3); AD- } \\
\text { HD } 1 \text { (n=1); } \\
\text { major de- } \\
\text { pression } \\
\text { (n=6); } \\
\text { Alzheimer } \\
\text { disease } \\
(n=1) ; \text { eat- } \\
\text { ing disor- } \\
\text { ders ( } n=1 \text { ) }\end{array}$ & $\begin{array}{l}\text { Analysis } \\
\text { of assess- } \\
\text { ment, NR } \\
(9-68) ; \\
\text { analysis } \\
\text { of effica- } \\
\text { cy, NR } \\
(9-65)\end{array}$ & NR & $\begin{array}{l}\text { United States } \\
(\mathrm{n}=17) ; \text { Cana- } \\
\text { da }(\mathrm{n}=2) ; \\
\text { Japan }(\mathrm{n}=2) ; \\
\text { China }(\mathrm{n}=1) ; \\
\text { New Zealand } \\
(\mathrm{n}=1) ; \text { India } \\
(\mathrm{n}=1) ; \text { Nor- } \\
\text { way }(\mathrm{n}=1) ; \\
\text { Spain }(\mathrm{n}=1)\end{array}$ & Low \\
\hline
\end{tabular}




\begin{tabular}{|c|c|c|c|c|c|c|c|c|c|c|c|}
\hline Study & $\begin{array}{l}\text { Intervention type } \\
\text { (number of stud- } \\
\text { ies) }\end{array}$ & $\begin{array}{l}\text { Comparator } \\
\text { (number of } \\
\text { studies) }\end{array}$ & $\begin{array}{l}\text { Search } \\
\text { dates }\end{array}$ & $\begin{array}{l}\text { Number } \\
\text { of stud- } \\
\text { ies in- } \\
\text { cluded }\end{array}$ & $\begin{array}{l}\text { Study de- } \\
\text { signs } \\
\text { (number } \\
\text { of stud- } \\
\text { ies) }\end{array}$ & $\begin{array}{l}\text { Patients } \\
\text { includ- } \\
\text { ed, n (\% } \\
\text { female) }\end{array}$ & $\begin{array}{l}\text { Diagnoses } \\
\text { (number of } \\
\text { studies) }\end{array}$ & $\begin{array}{l}\text { Popula- } \\
\text { tion age } \\
\text { in years, } \\
\text { mean } \\
\text { (range) }\end{array}$ & $\begin{array}{l}\text { Ethnic- } \\
\text { ity, n } \\
(\%)\end{array}$ & $\begin{array}{l}\text { Countries cov- } \\
\text { ered (number } \\
\text { of studies) }\end{array}$ & $\begin{array}{l}\text { Quality } \\
\text { ap- } \\
\text { praisal } \\
\text { rating } \\
\text { (AM- } \\
\text { STAR } \\
2^{\text {a })}\end{array}$ \\
\hline $\begin{array}{l}\text { Hassan } \\
\text { and } \\
\text { Sharif } \\
\text { (2019) } \\
\text { [29] }\end{array}$ & $\begin{array}{l}\text { Not specified } \\
\text { videoconferenc- } \\
\text { ing treatment in- } \\
\text { tervention }(n=2) \text {; } \\
\text { video-based CBT } \\
(\mathrm{n}=7) \text {; video- } \\
\text { based psychoedu- } \\
\text { cation ( } \mathrm{n}=2) \text {; } \\
\text { video-based re- } \\
\text { lapse prevention } \\
(\mathrm{n}=1) \text {; video- } \\
\text { based treatment } \\
\text { management } \\
(\mathrm{n}=1) \text {; video- } \\
\text { based evaluation } \\
\text { of competency to } \\
\text { stand trial }(\mathrm{n}=1)\end{array}$ & $\begin{array}{l}\text { Face-to-face } \\
(n=14)\end{array}$ & $\begin{array}{l}2000- \\
2017\end{array}$ & 14 & $\begin{array}{l}\mathrm{RCT} \\
(\mathrm{n}=14)\end{array}$ & $\begin{array}{l}1714 \\
(\mathrm{NR})\end{array}$ & $\begin{array}{l}\text { Multiple } \\
(\mathrm{n}=4) ; \text { de- } \\
\text { pression } \\
(\mathrm{n}=5) ; \text { pan- } \\
\text { ic disorder } \\
(\mathrm{n}=1) ; \\
\text { PTSD } \\
(\mathrm{n}=1) ; \\
\text { schizophre- } \\
\text { nia }(\mathrm{n}=1) ; \\
\text { bulimia } \\
\text { nervosa } \\
(\mathrm{n}=1) ; \\
\text { mental in- } \\
\text { competen- } \\
\text { cy }(\mathrm{n}=1)\end{array}$ & NR & NR & $\begin{array}{l}\text { Canada }(n=5) ; \\
\text { United States } \\
(n=8) ; \text { Spain } \\
(n=1)\end{array}$ & $\begin{array}{l}\text { Critical- } \\
\text { ly low }\end{array}$ \\
\hline $\begin{array}{l}\text { Lin et al } \\
(2019) \\
{[30]}\end{array}$ & $\begin{array}{l}\text { Psychotherapy } \\
(n=10) ; \text { medica- } \\
\text { tion }(n=3)\end{array}$ & $\begin{array}{l}\text { Face-to-face } \\
\text { psychothera- } \\
\text { py }(n=7) ; \\
\text { telephone } \\
(n=2) ; \text { TAU } \\
(n=1) \text {; no } \\
\text { comparator } \\
(n=3)\end{array}$ & $\begin{array}{l}1998- \\
2018\end{array}$ & 13 & $\begin{array}{l}\text { RCT } \\
(n=7) ; \\
\text { quasiex- } \\
\text { perimen- } \\
\text { tal }(n=1) \text {; } \\
\text { nonran- } \\
\text { domized } \\
\text { pilot stud- } \\
\text { ies }(n=2) \text {; } \\
\text { retrospec- } \\
\text { tive stud- } \\
\text { ies }(n=3)\end{array}$ & $\begin{array}{l}5546 \\
\text { (NR-sub- } \\
\text { stantial } \\
\text { variabili- } \\
\text { ty in } \\
\text { gender } \\
\text { report- } \\
\text { ed) }\end{array}$ & $\begin{array}{l}\text { Substance } \\
\text { use disor- } \\
\text { ders, includ- } \\
\text { ing alcohol } \\
(n=5), \text { nico- } \\
\text { tine }(n=3) \text {, } \\
\text { opioid } \\
(n=5)\end{array}$ & $\begin{array}{l}\text { NR } \\
(30.5-52 ; \\
1 \text { study } \\
\text { did not re- } \\
\text { port) }\end{array}$ & NR & $\begin{array}{l}\text { United States } \\
(\mathrm{n}=10) \text {; Cana- } \\
\text { da }(\mathrm{n}=2) ; \text { Den- } \\
\text { mark }(\mathrm{n}=1)\end{array}$ & $\begin{array}{l}\text { Moder- } \\
\text { ate }\end{array}$ \\
\hline $\begin{array}{l}\text { Lins et al } \\
(2014) \\
{[31]}\end{array}$ & $\begin{array}{l}\text { Telephone coun- } \\
\text { seling }(n=9)\end{array}$ & $\begin{array}{l}\text { Friendly } \\
\text { calls }(n=3) ; \\
\text { TAU }(n=6)\end{array}$ & $\begin{array}{l}2000- \\
2008\end{array}$ & 12 & $\begin{array}{l}\text { RCT (effi- } \\
\text { cacy: } \\
\mathrm{n}=9 \text { ); } \\
\text { qualita- } \\
\text { tive study } \\
\text { (experi- } \\
\text { ence of } \\
\text { interven- } \\
\text { tion: } n=3 \text { ) }\end{array}$ & NR & $\begin{array}{l}\text { Depressive } \\
\text { symptoms } \\
(\mathrm{n}=8) ; \text { anxi- } \\
\text { ety symp- } \\
\text { toms }(\mathrm{n}=1)\end{array}$ & $\begin{array}{l}\text { NR }(60- \\
66)\end{array}$ & NR & $\begin{array}{l}\text { United States } \\
(\mathrm{n}=8) ; \text { Ger- } \\
\text { many }(\mathrm{n}=1) ; \\
\text { Canada or } \\
\text { United States } \\
(\mathrm{n}=3)\end{array}$ & $\begin{array}{l}\text { Moder- } \\
\text { ate }\end{array}$ \\
\hline
\end{tabular}




\begin{tabular}{|c|c|c|c|c|c|c|c|c|c|c|c|}
\hline Study & $\begin{array}{l}\text { Intervention type } \\
\text { (number of stud- } \\
\text { ies) }\end{array}$ & $\begin{array}{l}\text { Comparator } \\
\text { (number of } \\
\text { studies) }\end{array}$ & $\begin{array}{l}\text { Search } \\
\text { dates }\end{array}$ & $\begin{array}{l}\text { Number } \\
\text { of stud- } \\
\text { ies in- } \\
\text { cluded }\end{array}$ & $\begin{array}{l}\text { Study de- } \\
\text { signs } \\
\text { (number } \\
\text { of stud- } \\
\text { ies) }\end{array}$ & $\begin{array}{l}\text { Patients } \\
\text { includ- } \\
\text { ed, n (\% } \\
\text { female) }\end{array}$ & $\begin{array}{l}\text { Diagnoses } \\
\text { (number of } \\
\text { studies) }\end{array}$ & $\begin{array}{l}\text { Popula- } \\
\text { tion age } \\
\text { in years, } \\
\text { mean } \\
\text { (range) }\end{array}$ & $\begin{array}{l}\text { Ethnic- } \\
\text { ity, } \mathrm{n} \\
(\%)\end{array}$ & $\begin{array}{l}\text { Countries cov- } \\
\text { ered (number } \\
\text { of studies) }\end{array}$ & $\begin{array}{l}\text { Quality } \\
\text { ap- } \\
\text { praisal } \\
\text { rating } \\
\text { (AM- } \\
\text { STAR } \\
2^{\mathrm{a}} \text { ) }\end{array}$ \\
\hline $\begin{array}{l}\text { Muskens } \\
\text { et al } \\
(2014) \\
{[32]}\end{array}$ & $\begin{array}{l}\text { Telephone diag- } \\
\text { nostic interview- } \\
\text { ing }(n=16)\end{array}$ & $\begin{array}{l}\text { Traditional } \\
\text { face-to-face } \\
\text { diagnostic } \\
\text { interviewing }\end{array}$ & $\begin{array}{l}\text { NR } \\
\text { (search } \\
\text { was } \\
\text { con- } \\
\text { ducted } \\
\text { in } \\
\text { 2012) }\end{array}$ & 16 & NR & $\begin{array}{l}1001 \\
(\mathrm{NR})\end{array}$ & $\begin{array}{l}\text { Studies } \\
\text { conducted } \\
\text { diagnostic } \\
\text { interview- } \\
\text { ing for a } \\
\text { range of di- } \\
\text { agnoses in- } \\
\text { cluding de- } \\
\text { pression, } \\
\text { anxiety, } \\
\text { substance } \\
\text { misuse, } \\
\text { psychotic } \\
\text { disorders, } \\
\text { autism, } \\
\text { PTSD, } \\
\text { manic } \\
\text { episodes or } \\
\text { mania, pan- } \\
\text { ic disorder, } \\
\text { social pho- } \\
\text { bia, simple } \\
\text { phobia, } \\
\text { dysthymia. } \\
\text { Included } \\
\text { studies in- } \\
\text { terviewed } \\
\text { for be- } \\
\text { tween } 1 \\
\text { and } 21 \text { dis- } \\
\text { orders }\end{array}$ & $\begin{array}{l}\text { NR } \\
(8.92- \\
76.9)\end{array}$ & NR & $\begin{array}{l}\text { United States } \\
(n=10) ; \text { Unit- } \\
\text { ed Kingdom } \\
(n=2) ; \text { Brazil } \\
(n=1) ; \text { Aus- } \\
\text { tralia }(n=1) ; \\
\text { Canada }(n=1) ; \\
\text { Iran }(n=1)\end{array}$ & $\begin{array}{l}\text { Moder- } \\
\text { ate }\end{array}$ \\
\hline $\begin{array}{l}\text { Naslund } \\
\text { et al } \\
(2020) \\
{[33]}\end{array}$ & $\begin{array}{l}\text { Videoconference } \\
\text { for psychiatric or } \\
\text { neurological as- } \\
\text { sessment or treat- } \\
\text { ment ( } \mathrm{n}=23) \text {; } \\
\text { videotaping psy- } \\
\text { chiatric histories } \\
(\mathrm{n}=1) \text {; sending } \\
\text { clinical informa- } \\
\text { tion electronical- } \\
\text { ly to psychiatrist } \\
\text { for diagnosis and } \\
\text { treatment plan } \\
(\mathrm{n}=1) \text {; therapy } \\
\text { via text messages } \\
(\mathrm{n}=1)\end{array}$ & $\begin{array}{l}\text { Face-to-face } \\
(n=26)\end{array}$ & $\begin{array}{l}2000- \\
2018\end{array}$ & 26 & $\begin{array}{l}\text { RCT } \\
(\mathrm{n}=11) ; \\
\text { observa- } \\
\text { tional } \\
\text { study } \\
(\mathrm{n}=10) ; \\
\text { pre-post } \\
\text { study } \\
(\mathrm{n}=3) ; \\
\text { quasiex- } \\
\text { perimen- } \\
\text { tal }(\mathrm{n}=2)\end{array}$ & $\begin{array}{l}17,967 \\
(\mathrm{NR})\end{array}$ & $\begin{array}{l}\text { Depression } \\
(\mathrm{n}=7) \text {; gen- } \\
\text { eral mental } \\
\text { disorders } \\
(\mathrm{n}=7) ; \\
\text { child men- } \\
\text { tal health } \\
\text { ( } \mathrm{n}=4) \text {; geri- } \\
\text { atric men- } \\
\text { tal health } \\
(\mathrm{n}=4) ; \\
\text { PTSD } \\
\text { (n=2); suici- } \\
\text { dal } \\
\text { ideation } \\
(\mathrm{n}=1) ; \\
\text { epilepsy } \\
(\mathrm{n}=1)\end{array}$ & NR & NR & $\begin{array}{l}\text { Canada }(n=4) ; \\
\text { Colombia } \\
(n=1) ; \text { United } \\
\text { States }(n=15) ; \\
\text { Spain }(n=1) ; \\
\text { Germany } \\
(n=1) ; \text { Aus- } \\
\text { tralia }(n=2) ; \\
\text { Israel }(n=1) ; \\
\text { Hong Kong } \\
(n=1)\end{array}$ & $\begin{array}{l}\text { Critical- } \\
\text { ly low }\end{array}$ \\
\hline
\end{tabular}




\begin{tabular}{|c|c|c|c|c|c|c|c|c|c|c|c|}
\hline Study & $\begin{array}{l}\text { Intervention type } \\
\text { (number of stud- } \\
\text { ies) }\end{array}$ & $\begin{array}{l}\text { Comparator } \\
\text { (number of } \\
\text { studies) }\end{array}$ & $\begin{array}{l}\text { Search } \\
\text { dates }\end{array}$ & $\begin{array}{l}\text { Number } \\
\text { of stud- } \\
\text { ies in- } \\
\text { cluded }\end{array}$ & $\begin{array}{l}\text { Study de- } \\
\text { signs } \\
\text { (number } \\
\text { of stud- } \\
\text { ies) }\end{array}$ & $\begin{array}{l}\text { Patients } \\
\text { includ- } \\
\text { ed, n (\% } \\
\text { female) }\end{array}$ & $\begin{array}{l}\text { Diagnoses } \\
\text { (number of } \\
\text { studies) }\end{array}$ & $\begin{array}{l}\text { Popula- } \\
\text { tion age } \\
\text { in years, } \\
\text { mean } \\
\text { (range) }\end{array}$ & $\begin{array}{l}\text { Ethnic- } \\
\text { ity, n } \\
(\%)\end{array}$ & $\begin{array}{l}\text { Countries cov- } \\
\text { ered (number } \\
\text { of studies) }\end{array}$ & $\begin{array}{l}\text { Quality } \\
\text { ap- } \\
\text { praisal } \\
\text { rating } \\
\text { (AM- } \\
\text { STAR } \\
2^{\mathrm{a}} \text { ) }\end{array}$ \\
\hline $\begin{array}{l}\text { Olthuis et } \\
\text { al } \\
(2016 a) \\
{[35]}\end{array}$ & $\begin{array}{l}\text { Internet CBT } \\
\text { with therapist } \\
\text { email or tele- } \\
\text { phone support } \\
(\mathrm{n}=37) \text {; internet } \\
\text { behavioral thera- } \\
\text { py with exposure } \\
(\mathrm{n}=1)\end{array}$ & $\begin{array}{l}\text { Waitlist or } \\
\text { attentional } \\
\text { control } \\
(n=20) \text {; face } \\
\text { to face } \\
(n=7) \text {; other } \\
\text { internet ther- } \\
\text { apies ( } n=6 \text {; } \\
\text { multiple con- } \\
\text { trol groups } \\
(n=5)\end{array}$ & $\begin{array}{l}\text { Up to } \\
2015\end{array}$ & 30 & RCT & $\begin{array}{l}218 \\
(67.1)\end{array}$ & $\begin{array}{l}\text { Social pho- } \\
\text { bia }(n=11) \text {; } \\
\text { PD with or } \\
\text { without } \\
\text { agorapho- } \\
\text { bia }(n=8) ; \\
\text { GAD } \\
(n=5) ; \\
\text { PTSD } \\
(n=2) ; \\
\text { OCD } \\
(n=2) ; \text { spe- } \\
\text { cific pho- } \\
\text { bia }(n=2) \text {; } \\
\text { mixed anxi- } \\
\text { ety }(n=8)\end{array}$ & $\begin{array}{l}37.3 \\
(\mathrm{NR})\end{array}$ & NR & $\begin{array}{l}\begin{array}{l}\text { Sweden } \\
(\mathrm{n}=18) ; \text { Aus- }\end{array} \\
\text { tralia }(\mathrm{n}=14) ; \\
\text { Switzerland } \\
(\mathrm{n}=3) ; \text { Nether- } \\
\text { lands }(\mathrm{n}=2) ; \\
\text { United States } \\
(\mathrm{n}=1)\end{array}$ & $\begin{array}{l}\text { Moder- } \\
\text { ate }\end{array}$ \\
\hline $\begin{array}{l}\text { Olthuis et } \\
\text { al } \\
(2016 b) \\
{[36]}\end{array}$ & $\begin{array}{l}\text { Internet CBT } \\
\text { (with therapist } \\
\text { contact) or CBT } \\
\text { by phone }(n=19)\end{array}$ & $\begin{array}{l}\text { Face-to-face } \\
(\mathrm{n}=8) ; \text { inter- } \\
\text { net-based } \\
\text { supportive } \\
\text { counseling } \\
(\mathrm{n}=1) ; \text { TAU } \\
(\mathrm{n}=2) ; \text { tele- } \\
\text { phone }(\mathrm{n}=1) ; \\
\text { self-help } \\
\text { iCBT }^{\mathrm{n}} \\
(\mathrm{n}=1) ; \text { wait- } \\
\text { ing list }(\mathrm{n}=6)\end{array}$ & $\begin{array}{l}\text { Up to } \\
2016\end{array}$ & 19 & $\mathrm{RCT}$ & $\begin{array}{l}1491 \\
(67.7)\end{array}$ & $\begin{array}{l}\text { PTSD } \\
(n=13) ; \\
\text { subclinical } \\
\text { PTSD } \\
(n=6)\end{array}$ & NR & NR & $\begin{array}{l}\text { United States } \\
(\mathrm{n}=13) ; \text { Swe- } \\
\text { den }(\mathrm{n}=3) ; \\
\text { Germany } \\
(\mathrm{n}=1) ; \text { Aus- } \\
\text { tralia }(\mathrm{n}=2)\end{array}$ & $\begin{array}{l}\text { Moder- } \\
\text { ate }\end{array}$ \\
\hline $\begin{array}{l}\text { Sansom- } \\
\text { Daly et al } \\
(2016) \\
{[37]}\end{array}$ & $\begin{array}{l}\text { N/A }{ }^{\mathrm{o}} \text { (systematic } \\
\text { review of guide- } \\
\text { lines) }\end{array}$ & N/A & $\begin{array}{l}2004- \\
2014\end{array}$ & 20 & N/A & N/A & N/A & N/A & N/A & $\begin{array}{l}\text { United States } \\
(\mathrm{n}=10) ; \text { Cana- } \\
\text { da }(\mathrm{n}=5) ; \text { Aus- } \\
\text { tralia }(\mathrm{n}=1) ; \\
\text { United King- } \\
\text { dom }(\mathrm{n}=1) ; \\
\text { Europe }(\mathrm{n}=1) \text {; } \\
\text { South Africa } \\
(\mathrm{n}=1) ; \text { New } \\
\text { Zealand }(\mathrm{n}=1)\end{array}$ & Low \\
\hline
\end{tabular}




\begin{tabular}{|c|c|c|c|c|c|c|c|c|c|c|c|}
\hline Study & $\begin{array}{l}\text { Intervention type } \\
\text { (number of stud- } \\
\text { ies) }\end{array}$ & $\begin{array}{l}\text { Comparator } \\
\text { (number of } \\
\text { studies) }\end{array}$ & $\begin{array}{l}\text { Search } \\
\text { dates }\end{array}$ & $\begin{array}{l}\text { Number } \\
\text { of stud- } \\
\text { ies in- } \\
\text { cluded }\end{array}$ & $\begin{array}{l}\text { Study de- } \\
\text { signs } \\
\text { (number } \\
\text { of stud- } \\
\text { ies) }\end{array}$ & $\begin{array}{l}\text { Patients } \\
\text { includ- } \\
\text { ed, n (\% } \\
\text { female) }\end{array}$ & $\begin{array}{l}\text { Diagnoses } \\
\text { (number of } \\
\text { studies) }\end{array}$ & $\begin{array}{l}\text { Popula- } \\
\text { tion age } \\
\text { in years, } \\
\text { mean } \\
\text { (range) }\end{array}$ & $\begin{array}{l}\text { Ethnic- } \\
\text { ity, n } \\
(\%)\end{array}$ & $\begin{array}{l}\text { Countries cov- } \\
\text { ered (number } \\
\text { of studies) }\end{array}$ & $\begin{array}{l}\text { Quality } \\
\text { ap- } \\
\text { praisal } \\
\text { rating } \\
\text { (AM- } \\
\text { STAR } \\
2^{\mathrm{a}} \text { ) }\end{array}$ \\
\hline $\begin{array}{l}\text { Turgoose } \\
\text { et al } \\
(2018) \\
{[38]}\end{array}$ & $\begin{array}{l}\text { Video-based ex- } \\
\text { posure }(\mathrm{n}=10) ; \\
\text { video-based cog- } \\
\text { nitive processing } \\
\text { therapy ( } \mathrm{n}=6) ; \\
\text { video-based CBT } \\
(\mathrm{n}=5) \text {; mixed in- } \\
\text { terventions } \\
(\mathrm{n}=11) \text {; telephone } \\
\text { mindfulness } \\
(\mathrm{n}=1) \text {; video- } \\
\text { based behavioral } \\
\text { activation ( } \mathrm{n}=2) \text {; } \\
\text { video-based eye } \\
\text { movement desen- } \\
\text { sitization and re- } \\
\text { processing ( } \mathrm{n}=1) \text {; } \\
\text { video-based } \\
\text { anger manage- } \\
\text { ment ( } \mathrm{n}=2 \text { ); } \\
\text { video-based gen- } \\
\text { eral coping and } \\
\text { psychoeducation } \\
\text { interventions } \\
(\mathrm{n}=3 \text { ) }\end{array}$ & $\begin{array}{l}\text { Face-to-face } \\
(n=41)\end{array}$ & $\begin{array}{l}\text { Up to } \\
2018\end{array}$ & 41 & $\begin{array}{l}\text { NR. A } \\
\text { mix of ex- } \\
\text { perimen- } \\
\text { tal and } \\
\text { nonexperi- } \\
\text { mental } \\
\text { designs }\end{array}$ & $\begin{array}{l}4130 \\
(\mathrm{NR})\end{array}$ & $\begin{array}{l}\text { PTSD } \\
(n=41)\end{array}$ & NR & NR & $\begin{array}{l}\text { United States } \\
(\mathrm{n}=40) ; \text { Cana- } \\
\text { da }(n=1)\end{array}$ & $\begin{array}{l}\text { Critical- } \\
\text { ly low }\end{array}$ \\
\hline
\end{tabular}

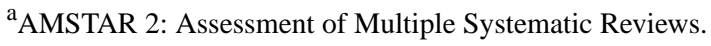

${ }^{\mathrm{b}} \mathrm{NR}$ : not reported.

CTAU: treatment as usual.

${ }^{\mathrm{d}} \mathrm{RCT}$ : randomized controlled trial.

${ }^{\mathrm{e}} \mathrm{CBT}$ : cognitive behavioral therapy.

${ }^{f}$ PTSD: posttraumatic stress disorder.

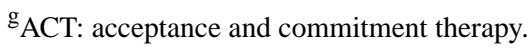

${ }^{\mathrm{h}} \mathrm{PD}$ : Parkinson disease.

${ }^{\mathrm{i}}$ GAD: generalized anxiety disorder.

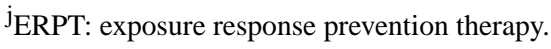

${ }^{k}$ OCD: obsessive-compulsive disorder.

${ }^{1}$ ADHD: attention-deficit/hyperactivity disorder.

${ }^{m}$ EDNOS: eating disorders not otherwise specified.

$\mathrm{n}_{\mathrm{iCBT}}$ : internet-based cognitive behavioral therapy.

${ }^{\mathrm{o}} \mathrm{N} / \mathrm{A}$ : not applicable.

\section{Data Synthesis}

Heterogeneity in study populations and interventions included in the review, as well as broad inclusion criteria for review study design (eg, qualitative and quantitative), prevented the quantitative pooling of syntheses. As a result, we conducted a narrative synthesis of all interventions and outcomes [39]. This allowed for a more in-depth consideration of all outcome measures and variations in the remote intervention delivery. We grouped reviews by the included population (mental health diagnosis) and further considered the variation in interventions on offer within these subgroups. This was performed for each outcome of interest. Most reviews provided a synthesis of multiple intervention types or failed to adequately differentiate them, making a more thorough comparison across formats impossible.

\section{Results}

\section{Overview}

The search returned 1086 reviews, of which 292 potentially relevant full-text articles were identified. Following full-text checks, 19 reviews met the inclusion criteria (Figure 1), reporting 239 individual studies and 20 guidance documents. In total, 15 of the included reviews examined the clinical effectiveness of telemental health as compared with (1) 
face-to-face interventions and assessments $(n=4),(2)$ treatment as usual $(n=2)$, or (3) a variety of comparators, including face-to-face, telephone, and treatment as usual $(n=9)$. Eight reviews reported on implementation (broadly defined), including process variables, fidelity, and uptake of interventions, and 10 reviews reported outcomes related to acceptability, including the satisfaction of both service users and clinicians. In total, 1 review focused specifically on the differences in therapeutic alliances between treatment modalities. A total of 2 reviews reported cost-effectiveness, one on this topic only and the other in combination with clinical effectiveness. One review synthesized international guidance on the conduct of videoconferencing-based mental health treatments. Table 1 presents full details of the included reviews, and Figure 1 shows the information on the search and screening process.

Some primary studies were included in more than 1 review: 26 studies appeared in 2 reviews and 27 studies appeared in 3 or more. The remaining 186 studies were included in only 1 review. The double counting of primary studies due to inclusion in multiple reviews contributing to the same outcome was only found for clinical effectiveness outcomes. However, conclusions were similar across reviews, and no review had all the same studies contributing to any synthesis. Multimedia Appendix 2 [20-36,38,40-276] and Multimedia Appendix 3 [40-276] present further details of the study overlap.

Figure 1. PRISMA (Preferred Reporting Items for Systematic Reviews and Meta-Analyses) diagram.

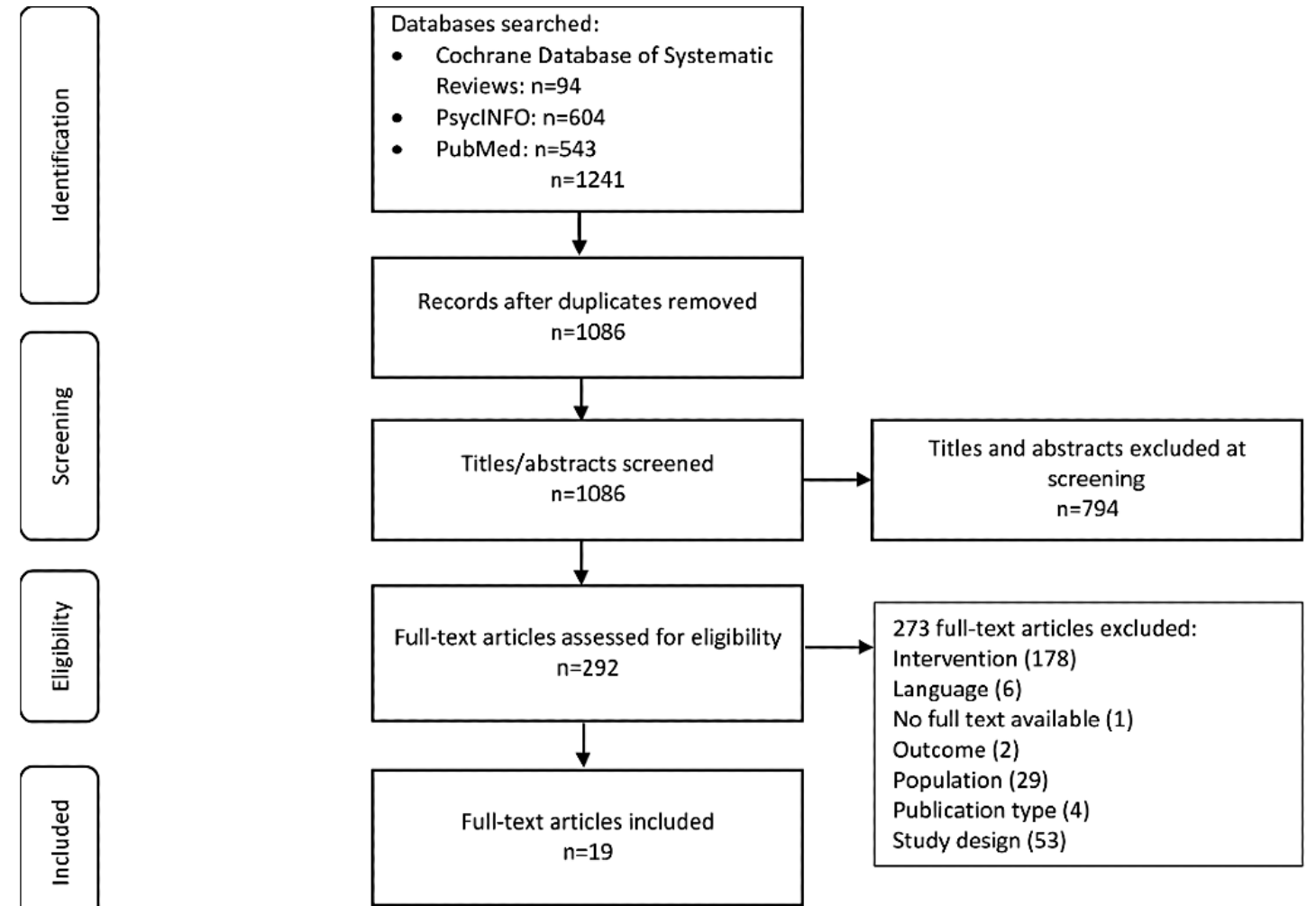

\section{Quality of Included Reviews}

Most reviews elicited low confidence in quality appraisal because of multiple weaknesses in the study design. The most common weaknesses were a lack of explicit statements that a protocol was developed before the commencement of the review (explicit statements were reported in two reviews [20,35]), lack of duplicate study selection (duplicate selection was reported in five reviews [28,31,32,35,37]), no report of excluded studies and reasons for exclusion (exclusions were reported in two reviews $[31,35]$ ), and no report of sources of funding (sources of funding were reported in three reviews [26,27,31]). Meta-analysis was not performed in the majority of reviews, usually because of heterogeneous data or aims centering around more narrative conclusions such as acceptability $(n=12)$ but in those that included meta-analysis [24,27,31,34-36], all except two [31,34] reviews assessed publication bias. The potential impact of risk of bias was only assessed in two reviews performing meta-analysis $[31,34]$, but all reviews performing meta-analysis used appropriate statistical methods for combining results. The reviews eliciting higher confidence (moderate) were two Cochrane reviews [31,36]. Table 1 presents the quality ratings of reviews, and Multimedia Appendix 4 [20-32,34-38] shows the full details of quality assessments.

\section{Clinical Outcomes}

Clinical outcomes were reported in 15 reviews [20-24,26-31,34-36,38]. Across all patient populations, including patients with anxiety $(n=3)$, posttraumatic stress disorder (PTSD; $\mathrm{n}=2)$, depression $(\mathrm{n}=4)$ (including in ethnic minorities, $\mathrm{n}=1$ [21], and older adults, $n=1[20])$, substance use disorders $(n=1)$, and multiple disorders $(n=4)$, videoconferencing interventions have been reported to cause significant reductions in symptom severity, with outcomes comparable with face-to-face controls where these were included. Telephone-based interventions tended to report similar significant reductions in symptom severity. However, a review of telephone interventions with older adults with depression [20] reported more mixed findings: reductions were reported in emergency room and hospital visits in one study, and in depression in another; however, a third 
study suggested that telephone interventions did not add to benefit gained from a web-only intervention. Follow-up treatment gains were less widely reported, and conclusions were mixed across the reviews. Although the maintenance of improvements was found at varying follow-up assessments in one review [34] and at 3-6 months in two additional reviews $[26,38]$, two other reviews reported that evidence was inconsistent with some studies reporting that videoconference interventions may show less longevity in the maintenance of effects up to 6 months compared with face-to-face interventions $[21,24]$. A final review of mixed modality remote interventions suggested that although inferior to face-to-face formats at shorter follow-up, remote interventions may be more beneficial than face-to-face interventions at longer follow-ups (36 months) [20]. Table 2 presents further details on the clinical outcomes. 
Table 2. Clinical effectiveness outcomes.

\begin{tabular}{llll}
\hline $\begin{array}{l}\text { Main diagno- } \\
\text { sis }\end{array}$ & Study & $\begin{array}{l}\text { Intervention (number } \\
\text { of studies) }\end{array}$ & $\begin{array}{l}\text { Compara- } \\
\text { tor (num- } \\
\text { ber of stud- } \\
\text { ies) }\end{array}$ \\
\hline
\end{tabular}

\section{Anxiety}

Berryhill et Video-based CBT ${ }^{\mathrm{a}}$ al $(2019 b) \quad(n=12)$; video-based [23] behavioral activation $(\mathrm{n}=3)$; video-based $\mathrm{ACT}^{\mathrm{b}}(\mathrm{n}=1)$; videobased exposure therapy $(\mathrm{n}=2)$; video-based problem-solving therapy $(\mathrm{n}=1)$; video-based metacognitive therapy $(\mathrm{n}=1)$; multiple modality $(\mathrm{n}=1)$

Coughtrey Telephone-based CBT Face-toand Pis- $\quad(n=2)$; telephonetrang based exposure re(2018) [26] sponse prevention therapy $(n=1)$; telephone-based behavioral therapy $(\mathrm{n}=1)$

Olthuis et Internet CBT with al (2016a) therapist email or [35] telephone support $(\mathrm{n}=37)$; internet behavioral therapy with exposure $(n=1)$
Face-toface psychotherapy $(\mathrm{n}=20)$; no control $(n=1)$ face exposure response therapy $(\mathrm{n}=1)$; waitlist $(\mathrm{n}=3)$

Waitlist or attentional control $(n=20)$; face to face $(\mathrm{n}=7)$; other internetbased therapy $(\mathrm{n}=6)$; multiple control groups $(\mathrm{n}=5)$
In total, $66 \%(14 / 21)$ of studies found statisti- No combined data were available cally significant improvement on validated anxiety measures when videoconferencing psychological therapy was involved. A total of 52\% (11/21) of studies reported clinically significant improvements among participants. Controlled study designs comparing face-toface and videoconferencing psychological therapy sessions $(7 / 10,70 \%)$ found no statistical difference between them.

All $3 \mathrm{RCTs}^{\mathrm{c}}$ on anxiety reported significant reductions in anxiety symptoms following telephone-delivered intervention $\left(\mathrm{OCD}^{\mathrm{d}}\right.$ : comparable reductions with face-to-face treatment, maintained over 6-month followup. Panic disorder: significant reductions in panic and gains maintained over 3-month follow-up. Transdiagnostic intervention: significant reductions in anxiety sensitivity, panic, social phobia and PTSD $^{\mathrm{e}}$ ). One quasiexperimental study found significant reductions in OCD symptoms as compared with controls maintained at 12-week follow-up.

Versus control: therapist-supported $\mathrm{iCBT}^{\mathrm{f}}$ showed significantly larger improvements in anxiety $(n=12)$, disorder-specific anxiety symptom severity $(n=30)$, and general anxiety symptom severity $(n=19)$ at posttreatment as compared with waiting list, attentional control, information only or internet-based discussion group only controls. Versus unguided iCBT: therapist-supported iCBT showed no difference in improvements in anxiety at posttreatment $(\mathrm{n}=1)$, disorder-specific anxiety symptom severity at posttreatment $(\mathrm{n}=5)$, and general anxiety symptom severity $(n=2)$ at posttreatment compared with unguided selfhelp iCBT. Versus face-to-face: therapistsupported iCBT showed no difference in improvements in anxiety at posttreatment $(n=4)$ and 6- to 12-month follow-up $(\mathrm{n}=3)$, disorderspecific anxiety symptom severity at posttreatment $(\mathrm{n}=7)$ and 6- to 12-month follow-up $(n=6)$ and general anxiety symptom severity $(n=6)$ at posttreatment and at 6- to 12-month follow-up ( $\mathrm{n}=5)$ as compared with face-toface CBT.
RCTs: Cohen $d$ range 0.34-1.07 (median 0.69; $\mathrm{n}=2$ ); uncontrolled: Cohen $d=1.07(\mathrm{n}=1)$

Waitlist, attentional control, information only or internet-based discussion group-only controls at

posttreatment: $\mathrm{SMD}^{\mathrm{g}}=-1.06(95 \%$ CI -1.29 to -0.82$), P<.001$; faceto-face CBT at posttreatment: $\mathrm{SMD}=0.06(95 \% \mathrm{CI}-0.25$ to 0.37 ); $P=.36$ (no difference between iCBT and face-to-face sessions) 


\begin{tabular}{llll}
\hline Main diagno- & Study & Intervention (number & Compara- \\
sis & & of studies) & tor (num- \\
& & ber of stud-
\end{tabular}

ies)

Turgoose $\quad$ Video-based exposure

et al $(2018, \quad(n=10)$; video-based

veterans) cognitive processing

[38]

therapy $(\mathrm{n}=6)$; video-
Face-to-

face $(n=41)$

based CBT $(\mathrm{n}=5)$;

mixed interventions

$(\mathrm{n}=11)$; telephone

mindfulness $(\mathrm{n}=1)$;

video-based behav-

ioral activation $(\mathrm{n}=2)$;

video-based eye

movement desensitiza-

tion and reprocessing

$(\mathrm{n}=1)$; video-based

anger management

$(n=2)$; video-based

general coping and

psychoeducation interventions $(\mathrm{n}=3)$

Olthuis et Video-based CBT al (2016b) $\quad(n=3)$; video-based cognitive processing therapy $(\mathrm{n}=3)$; internet CBT with therapist email or telephone support $(n=9)$; videobased prolonged exposure $(n=2)$; telephone mindfulness $(\mathrm{n}=1)$; video-based behavioral activation and exposure $(n=1)$

In total, 18 studies looked at the clinical effec- No combined data available tiveness of teletherapy interventions. All of these studies reported that teletherapy was associated with significant reductions in PTSD symptoms, regardless of the type of intervention used, except one study that only measured anger in veterans with PTSD. Of those studies that used follow-up measures, all but one found these changes to be present at 3 or 6 months following treatment. In total, $67 \%(12 / 18)$ of studies compared teletherapy with in-person interventions. In all, 9 studies concluded that teletherapy was as effective as in-person therapy. Two suggested in-person therapy produced significantly greater reductions in PTSD symptoms (though neither were randomized), and 1 study found that teletherapy was more effective than inperson therapy.

Face-toface $(n=8)$; internet-

based supportive counseling $(\mathrm{n}=1)$; treatment as usual $(n=2)$; telephone $(\mathrm{n}=1)$; selfhelp iCBT $(\mathrm{n}=1)$; waiting list $(\mathrm{n}=6)$
Overall, telehealth interventions showed significant improvement in PTSD symptoms postintervention $(\mathrm{n}=18)$, at 3- to 6-month follow-up ( $\mathrm{n}=11)$, and at 7- to 12-month follow-up ( $\mathrm{n}=3)$; videoconferencing: in total, 9 studies examined videoconferencing interventions for PTSD. Results showed a significant improvement in PTSD symptoms at postintervention. There was no difference in improvements in PTSD symptoms between telehealth and face-to-face interventions at posttreatment $(n=7)$; however, face-to-face interventions showed a significantly greater improvement at 3- to 6-month follow-up $(n=5)$. Internet-based therapy delivered with telephone or email support: in total, 8 studies examined internet-delivered interventions with telephone or email support. Results showed significant improvements in PTSD symptoms at postintervention. Furthermore, telehealth interventions were found to show a significantly greater improvement in PTSD symptoms as compared with waitlist controls $(n=6)$. There were no data comparing these interventions with face-to-face treatments. No follow-up data were available.
Total: within group: pre- and postintervention: $\mathrm{g}=0.81(95 \% \mathrm{CI}$ 0.65 to 0.97 ), $\mathrm{n}=18$ (favors tele-

health); preintervention to 3- to 6month follow-up: $\mathrm{g}=0.78$ (95\% CI 0.59 to 0.97 ), $n=11$ (favors telehealth) preintervention to 7- to 12 month follow-up: $\mathrm{g}=0.75$ (95\% CI 0.25 to 1.26 ), $n=3$ (favors telehealth); Between group: as compared with waitlist control postintervention: $\mathrm{g}=0.6$ (95\% CI 0.51 to $0.86), n=6$ (favors telehealth) compared with face-to-face treatment for PTSD postintervention: $\mathrm{g}=-0.05$ (95\% CI -0.31 to 0.20 ), $\mathrm{n}=7$ (no difference) compared with face-to-face treatment for PTSD 3- to 6-month follow-up: $g=-0.25$ (95\% CI -0.44 to -0.07 ), $\mathrm{n}=5$ (favors face-to-face). Videoconferencing: within group: pre- and postintervention: $\mathrm{g}=0.71$ (95\% CI 0.47 to 0.96 ), $n=8$ (favors telehealth). Between group: compared with waitlist control postintervention: No data compared with faceto-face treatment for PTSD postintervention: $\mathrm{g}=-0.05(95 \%$ CI -0.31 to 0.20 ), $\mathrm{n}=7$ (no difference). Internet-delivered interventions with telephone or email support. Within group: pre- and postintervention: $\mathrm{g}=0.94$ (95\% CI 0.69 to 1.20 ), $n=8$ (favors telehealth). Between group: compared with waitlist control postintervention: $\mathrm{g}=0.73$ (95\% CI 0.56 to $0.91), \mathrm{n}=5$ (favors telehealth) compared with face-to-face treatment for PTSD postintervention (no data) 


\begin{tabular}{llll}
\hline Main diagno- & Study & Intervention (number & Compara- \\
sis & & of studies) & tor (num- \\
& & ber of stud-
\end{tabular}

ies)

$\begin{array}{lll}\begin{array}{l}\text { Bolton and } \\ \text { Dorstyn }\end{array} & \begin{array}{l}\text { iCBT with therapist } \\ \text { support via telephone }\end{array} & \begin{array}{l}\text { Face-to- } \\ \text { face }(\mathrm{n}=5) \text {; }\end{array} \\ & \begin{array}{l}\text { calls, introductory } \\ \text { face-to-face meetings, }\end{array} & \text { supportive } \\ & \text { counseling } \\ & \text { or emails }(\mathrm{n}=6) ; & (\mathrm{n}=1) ; \\ & \text { video-based CBT } & \text { waitlist } \\ (\mathrm{n}=5) & (\mathrm{n}=1) ; \text { no } \\ & & \text { control } \\ & & (\mathrm{n}=4)\end{array}$

Therapist-assisted internet programs. Statisti- No useful synthesis of data cally significant reductions in the severity of depression and anxiety symptoms (including PTSD) were associated with therapist-assisted internet programs in five studies, including significant large reductions in fear reactions, suicidal ideation, social functioning, and insomnia. Treatment effects 1-6 months posttelepsychology were mixed, with both deterioration and continued improvement found in psychological functioning. This included an increased risk of alcohol consumption over time but also a decline in PTSD and depression symptoms in participants using internet programs. Videoconferencing: video-based interventions also produced short-term reductions in affective symptoms; however, faceto-face therapy demonstrated slightly higher treatment gains. The longer-term effectiveness of videoconferencing was reported in only two studies which showed nonsignificant effect sizes at follow-up.

\section{Depression}

$\begin{array}{ll}\text { Hareri- } & \text { Telephone-based } \\ \text { mana et al } & (\mathrm{n}=3) ; \text { video-based } \\ (2019, \text { old- } & (\mathrm{n}=2) ; \text { web based } \\ \text { er adults }) & (\mathrm{n}=1) \\ {[20]} & \end{array}$

Waiting Telephone: three studies examined a telelist phone-based intervention. One study found $\left(\mathrm{n}=\mathrm{NR}^{\mathrm{h}}\right) \quad$ that a home electronic messaging service retreatment duced emergency room and hospital visits. as usual Another study found that older adult veterans $(\mathrm{n}=\mathrm{NR}) \quad$ given a combined telephone-based psychotherapy and long-term illness management intervention showed significant reductions in depression as compared with usual care. However, a third study found that adding telecoaching to a web intervention did not significantly improve symptoms compared with providing only the web intervention. Videoconferencing: two studies examined Skypebased videoconferencing interventions with inconsistent results. One study found that depression scores improved significantly from baseline but got worse at the 2-month follow-up. Another found that face-to-face and Skype-based intervention were not significantly different at postintervention and shorter follow-ups, but at 36 months, the telehealth intervention showed significantly larger improvements in symptoms. Webbased CBT: one web-based CBT intervention was effective in reducing depression symptoms $(P=.04)$, even with high rates of attrition.
No combined data available 


\begin{tabular}{llll}
\hline $\begin{array}{l}\text { Main diagno- } \\
\text { sis }\end{array}$ & Study & $\begin{array}{l}\text { Intervention (number } \\
\text { of studies) }\end{array}$ & $\begin{array}{l}\text { Compara- } \\
\text { tor (num- } \\
\text { ber of stud- }\end{array}$
\end{tabular}

ies)

\begin{tabular}{|c|c|c|}
\hline $\begin{array}{l}\text { Berryhill et } \\
\text { al (2019a) } \\
{[22]}\end{array}$ & $\begin{array}{l}\text { Video-based CBT } \\
(\mathrm{n}=12) \text {; video-based } \\
\text { behavioral activation } \\
(\mathrm{n}=5) \text {; video-based } \\
\text { acceptance and behav- } \\
\text { ioral therapy }(\mathrm{n}=1) \text {; } \\
\text { video-based exposure } \\
(\mathrm{n}=3) \text {; video-based } \\
\text { metacognitive therapy } \\
(\mathrm{n}=1) \text {; video-based } \\
\text { problem-solving thera- } \\
\text { py }(\mathrm{n}=2) \text {; video-based } \\
\text { therapy in multiple } \\
\text { modalities }(\mathrm{n}=9)\end{array}$ & $\begin{array}{l}\text { Face-to- } \\
\text { face psy- } \\
\text { chotherapy } \\
(n=16) ; \\
\text { face-to- } \\
\text { face or tele- } \\
\text { phone } \\
(n=2) \text {; no } \\
\text { control } \\
(n=15)\end{array}$ \\
\hline
\end{tabular}

Coughtrey Telephone-based CBT Telephone

In total, $83 \%$ (5/6) of RCTs on depression

In total, $67 \%$ (22/33) of studies included re-

No combined data available ported statistically significant reductions in depressive symptoms following videoconference-based psychotherapy. Most controlled studies reported inconsistent results while comparing face-to-face and video-based psychotherapy. and Pis- $\quad(n=10) \quad$ emotion-fo-

trang cused thera-

py $(\mathrm{n}=1)$; treatment as usual $(\mathrm{n}=5)$; no control $(\mathrm{n}=4)$ reported a significant reduction in depression symptoms following telephone-delivered CBT $(n=3)$ or IPT ${ }^{\mathrm{i}}(\mathrm{n}=2)$. These studies included people with recurrent depression $(\mathrm{n}=1)$, HIV $(\mathrm{n}=1)$, multiple sclerosis $(\mathrm{n}=1)$, and people from rural Latino communities $(n=1)$. Two RCTs reported follow-up: only one of these found the maintenance of reductions in depressive symptoms. One RCT found that depression symptoms were not significantly reduced in veterans. One quasiexperimental study found significant reductions in depression following telephone-delivered CBT, with similar patterns of change found in the comparison group. Three uncontrolled studies reported statistically significant reductions in depression following telephonedelivered CBT, including people with Parkinson disease $(\mathrm{n}=1)$, HIV $(\mathrm{n}=1)$, and veterans with depression $(n=1)$.

Dorstyn et Telephone CBT al (2013; $\quad(n=2)$; telephone supminority portive counseling ethnicity $\quad(\mathrm{n}=1)$; telephone communi- structural ecosystems ties) [21] therapy $(\mathrm{n}=1)$; internet-based CBT with weekly individual sessions $(\mathrm{n}=2)$; internet telepsychiatry $(\mathrm{n}=1)$; internet supportive counseling and personalized email correspondence $(n=1)$
Face-to- Telephone- and internet-mediated services face $(n=1)$; were associated with significant improvetreatment ments in the measurements of depression, as usual anxiety, quality of life and psychosocial $(n=3)$; mini- functioning. The review also found that two mal sup- studies demonstrated similar effects on depresport consion ratings (CES-D $\left.{ }^{j}\right)$ in telephone and facelonger-term effects of telecounseling, with $(\mathrm{n}=2)$ conflicting findings.
RCTs: Cohen $d$ range: 0.25-1.98 (median 0.58), $\mathrm{n}=5$; uncontrolled: Cohen $d$ range: 1.13-1.90 (median $1.25), \mathrm{n}=2$

No combined data available 


\begin{tabular}{llll}
\hline $\begin{array}{l}\text { Main diagno- } \\
\text { sis }\end{array}$ & Study & $\begin{array}{l}\text { Intervention (number } \\
\text { of studies) }\end{array}$ & $\begin{array}{l}\text { Compara- } \\
\text { tor (num- } \\
\text { ber of stud- } \\
\text { ies) }\end{array}$
\end{tabular}

ies)

\begin{tabular}{lll}
\hline $\begin{array}{l}\text { Carers of peo- } \\
\text { ple with de- }\end{array}$ & $\begin{array}{l}\text { Lins et al } \\
\text { (2014) [31] }\end{array}$ & $\begin{array}{l}\text { Telephone counseling } \\
(\mathrm{n}=9)\end{array}$ \\
$\begin{array}{l}\text { mentia (for de- } \\
\text { pressive }\end{array}$ & & \\
symptoms) & &
\end{tabular}

Friendly calls $(n=3)$; treatment as usual $(\mathrm{n}=6)$

Substance use disorders

Lin et al Video or telephone(2019) [30] based psychotherapy $(\mathrm{n}=10)$; remote medication management $(\mathrm{n}=3$; patient presents at local clinic with nurse and is connected to a physician at a distant site via videoconference)

Face-toface psychotherapy $(\mathrm{n}=7)$; tele-

phone $(n=2)$; treatment as usual $(n=1)$; no control $(\mathrm{n}=3)$

Telephone counseling without any additional intervention showed significant reductions in depressive symptoms in three studies; however, two additional studies showed no differences between groups. A study of telephone counseling with video sessions showed reductions in depressive symptoms in the intervention group but these did not significantly differ from the control group. One study found that telephone counseling with video sessions and a workbook showed significant reductions in depressive symptoms. Burden, distress, anxiety, quality of life, satisfaction, and social support outcomes were inconsistent. Results show that it is still unclear whether telephone counseling can reduce caregiver burden.

Tobacco: videoconferencing interventions were not significantly better than in-person $(n=1)$ or telephone $(n=2)$ conditions in terms of abstinence. Alcohol: no significant difference in alcohol use outcomes as compared with usual treatment $(\mathrm{n}=1)$, but lower dropout was reported in the telemental health intervention $(\mathrm{n}=1)$. Opioid: no significant difference in abstinence between videoconference-based psychotherapy and in-person psychotherapy for methadone patients $(n=2)$, and no difference in time to abstinence $(\mathrm{n}=1)$. Notably, none of the included studies described a noninferiority design that specifically assessed whether the intervention was not significantly worse than usual in-person delivered care. Overall, most studies suggested telemental health interventions were an effective alternative, especially when access to treatment is otherwise limited.

\section{Nonspecific}

\begin{tabular}{|c|c|}
\hline $\begin{array}{l}\text { Hassan and } \\
\text { Sharif } \\
\text { (2019, } \\
\text { refugee } \\
\text { popula- } \\
\text { tions) [29] }\end{array}$ & $\begin{array}{l}\text { Not specified video- } \\
\text { conferencing treat- } \\
\text { ment intervention } \\
(\mathrm{n}=2) \text {; video-based } \\
\text { CBT }(\mathrm{n}=7) \text {; video- } \\
\text { based psychoeduca- } \\
\text { tion }(\mathrm{n}=2) \text {; video- } \\
\text { based relapse preven- } \\
\text { tion }(\mathrm{n}=1) \text {; video- } \\
\text { based treatment man- } \\
\text { agement }(\mathrm{n}=1) \text {; video- } \\
\text { based evaluation of } \\
\text { competency to stand } \\
\text { trial }(\mathrm{n}=1)\end{array}$ \\
\hline $\begin{array}{l}\text { Norwood } \\
\text { et al (2018) } \\
{[34]}\end{array}$ & $\begin{array}{l}\text { Video-based CBT } \\
(\mathrm{n}=10)\end{array}$ \\
\hline
\end{tabular}

Face-to- Five studies compared remote and face-toface $(n=14)$ face interventions in symptom reduction. Two reviews found greater improvement in the remote intervention, whereas 3 found no significant difference between the intervention and control groups.

Face-toface CBT $(\mathrm{n}=10)$
All 10 studies showed that video-based CBT No combined data available improved symptom severity. Eight studies offered follow-up data, and the postintervention improvement was maintained in all of them. Symptom reduction in video-based CBT was noninferior to face-to-face sessions across all six studies which offered a face-toface comparison. 


\begin{tabular}{|c|c|c|c|c|c|}
\hline $\begin{array}{l}\text { Main diagno- } \\
\text { sis }\end{array}$ & Study & $\begin{array}{l}\text { Intervention (number } \\
\text { of studies) }\end{array}$ & $\begin{array}{l}\text { Compara- } \\
\text { tor (num- } \\
\text { ber of stud- } \\
\text { ies) }\end{array}$ & Results & Data \\
\hline & $\begin{array}{l}\text { Drago et al } \\
(2016)[27]\end{array}$ & $\begin{array}{l}\text { Videoconferencing } \\
(\mathrm{n}=24)\end{array}$ & $\begin{array}{l}\text { Face-to- } \\
\text { face } \\
(\mathrm{n}=23) \text {. No } \\
\text { comparator } \\
(\mathrm{n}=1)\end{array}$ & $\begin{array}{l}\text { In total, } 14 \text { RCTs focused on efficacy of re- } \\
\text { mote psychiatric counseling. There was no } \\
\text { difference between treatment outcomes in } \\
\text { remote and face-to-face settings. }\end{array}$ & $\begin{array}{l}\text { Videoconferencing versus face-to- } \\
\text { face therapy: } \mathrm{SMD}=-0.11(95 \% \\
\mathrm{CI}-0.41 \text { to } 0.18)\end{array}$ \\
\hline & $\begin{array}{l}\text { Garcia- } \\
\text { Lizana and } \\
\text { Munoiz- } \\
\text { Mayorga } \\
(2010) \text { [28] }\end{array}$ & $\begin{array}{l}\text { Videoconferencing for } \\
\text { diagnosis and follow- } \\
\text { up }(n=3) \text {; video-based } \\
\text { evaluation of compe- } \\
\text { tency to stand trial } \\
(n=1) \text {; nonspecific } \\
\text { video-based CBT } \\
(n=5) \text {; video-based } \\
\text { psychoeducation and } \\
\text { counseling }(n=1)\end{array}$ & $\begin{array}{l}\text { Face-to- } \\
\text { face }(n=10)\end{array}$ & $\begin{array}{l}\text { Across seven studies, there was no statistical- } \\
\text { ly significant difference between telepsychia- } \\
\text { try and face-to-face interventions in symptom } \\
\text { reduction. Across three studies, there was no } \\
\text { statistically significant difference between } \\
\text { telepsychiatry in improvements in quality of } \\
\text { life. }\end{array}$ & No combined data available \\
\hline
\end{tabular}

${ }^{\mathrm{a} C B T}$ : cognitive behavioral therapy.

${ }^{\mathrm{b}}$ ACT: acceptance and commitment therapy.

${ }^{\mathrm{c}}$ RCTs: randomized controlled trials.

dOCD: obsessive-compulsive disorder.

${ }^{\mathrm{e}}$ PTSD: posttraumatic stress disorder.

$\mathrm{f}_{\mathrm{iCBT}}$ : internet-based cognitive behavioral therapy.

${ }^{\text {g }}$ SMD: standardized mean difference.

$\mathrm{h}_{\mathrm{NR}}$ : not reported.

${ }^{\mathrm{i}}$ IPT: interpersonal psychotherapy.

${ }^{j}$ CES-D: Center for Epidemiological Studies-Depression Scale.

\section{Implementation Outcomes}

\section{Overview}

Implementation outcomes were reported in eight reviews [21,24,25,27,28,30,32,38]. Relevant outcomes included assessment comparability ( $\mathrm{n}=2$ reviews), fidelity to intervention and competence of therapists $(\mathrm{n}=1)$ [38], patient adherence to intervention $(n=3) \quad[21,24,28]$, patient attendance $(n=4)$ $[21,25,30,38]$, safety $(n=2)[24,38]$, and technical difficulties $(n=3)[24,25,38]$.

\section{Assessment Comparability}

Limited evidence from one review suggests that videoconferencing can be used to conduct assessment, which is consistent with face-to-face assessment, with a correlation coefficient of 0.73 (95\% CI 0.63-0.83) between the conclusions of videoconference and face-to-face assessments [27]. A review of telephone assessments found lack of properly performed studies on telephone assessments [32].

\section{Fidelity and Competence of Therapists}

One review [38] found that fidelity and therapist competence using telemental health had been found to be comparable with face-to-face interventions in 3 studies of interventions for PTSD in veterans.

\section{Patient Adherence to Intervention}

From 3 reviews [21,24,28] examining patients' adherence to remote interventions the general consensus was that the comprehension of tasks and completion rates are high during both telephone and video-based CBT. However, another review reported mixed findings, with one of the two included relevant studies reporting better adherence in the face-to-face intervention group for patients with PTSD, whereas another study on patients with depression reported equivalent adherence in remote and face-to-face conditions [28].

\section{Patient Attendance}

An increase in uptake and access to care following the introduction of telemental health has been reported in the reviews of depression treatment in older adults [20], PTSD treatment in veterans [38], and substance use disorder treatment [30]. Dropouts tended to be comparable with face-to-face interventions [30,38]. However, one review included a study reporting difficulty in reaching ethnic minority patients with depression [21].

\section{Safety}

Patient safety while using remote interventions has been reported only in the reviews of populations with PTSD. Two reviews agreed that safety was acceptable, with one reporting that with correct steps taken, safety could usually be managed in remote settings [38], and another study reported that client safety was deemed satisfactory (however, no further details were provided on this result) [24].

\section{Technical Difficulties}

A total of 3 reviews reported technical difficulties, none of which were identified as severe barriers to the implementation 
of remote technology. A review of older adults with depression found that four studies reported mistrust in technology [25], while the challenges of a more logistical nature, such as low image resolution and connectivity problems, were reported in a review of video-based PTSD interventions for veterans [38].
Another review reported findings from one included study that participants preferred mobile apps to supplement remotely delivered support [24]. Table 3 presents further details on the implementation outcomes. 
Table 3. Implementation outcomes.

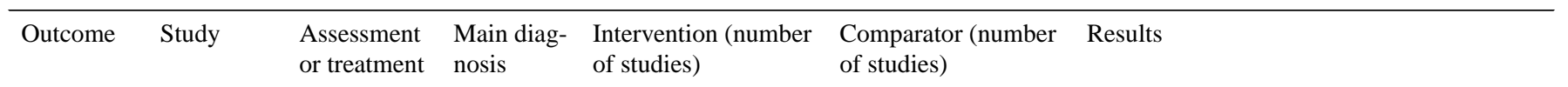

Assessment comparability

Drago et al Assessment Multiple (2016) [27] and treatment

Muskens et Assessment Multiple al (2014)

Fidelity Turgoose Treatment PTSD ${ }^{\mathrm{a}}$ and compe- et al (2018, tence of veterans) therapists [38]
Videoconferencing $(n=24)$

Telephone diagnostic interviewing $(n=16)$

Face-to-face diagnos$(\mathrm{n}=16)$ tic interviewing

Face-to-face $(\mathrm{n}=23) ; \quad$ Assessment was found to be highly consistent no comparator $(\mathrm{n}=1)$ between remote and face-to-face settings; correlation coefficient $=0.73(95 \%$ CI 0.63 0.83).

There were a few studies that were properly performed to draw conclusions regarding the comparability of telephone and face-to-face interviews for psychiatric morbidity. Telephone interviewing for research purposes in depression and anxiety may however be a valid method.

High levels of fidelity and therapist competence $(n=3)$, with no significant differences compared with face-to-face settings.

\section{Patient adherence to intervention}

Bolton and Treatment

Dorstyn

(2015) [24]
PTSD

Internet-based $\mathrm{CBT}^{\mathrm{b}}$ with therapist support via telephone calls, introductory face-toface meetings, or emails $(\mathrm{n}=6)$; videobased CBT $(\mathrm{n}=5)$

Dorstyn et Treatment al (2013,

ethnic minorities)

[21]
Face-to-face ( $\mathrm{n}=5)$; supportive counseling $(\mathrm{n}=1)$; waitlist $(\mathrm{n}=1)$; no control $(\mathrm{n}=4)$

Face-to-face $(\mathrm{n}=1)$; treatment as usual $(\mathrm{n}=3)$; minimal support control or waitlist $(\mathrm{n}=2)$; no control $(\mathrm{n}=2)$
Qualitative feedback revealed that the comprehension of the therapy materials was high, with participants completing a set of homework tasks $(\mathrm{n}=5)$.

Most studies reported good treatment adherence with rates of completion of $75-97 \%$. 


\begin{tabular}{|c|c|c|c|c|c|c|}
\hline Outcome & Study & $\begin{array}{l}\text { Assessment } \\
\text { or treatment }\end{array}$ & $\begin{array}{l}\text { Main diag- } \\
\text { nosis }\end{array}$ & $\begin{array}{l}\text { Intervention (number } \\
\text { of studies) }\end{array}$ & $\begin{array}{l}\text { Comparator (number } \\
\text { of studies) }\end{array}$ & Results \\
\hline & $\begin{array}{l}\text { Garcia- } \\
\text { Lizana and } \\
\text { Munoiz- } \\
\text { Mayorga } \\
(2010)[28]\end{array}$ & $\begin{array}{l}\text { Assessment } \\
\text { and treat- } \\
\text { ment }\end{array}$ & Multiple & $\begin{array}{l}\text { Videoconferencing for } \\
\text { diagnosis and follow- } \\
\text { up }(n=3) \text {; video-based } \\
\text { evaluation of compe- } \\
\text { tency to stand trial } \\
(n=1) \text {; nonspecific } \\
\text { video-based CBT } \\
(n=5) \text {; video-based } \\
\text { psychoeducation and } \\
\text { counseling }(n=1)\end{array}$ & Face-to-face $(n=10)$ & $\begin{array}{l}\text { Across two studies, mixed results were found } \\
\text { for treatment adherence, with one study } \\
\text { finding no difference and another reporting } \\
\text { better adherence in the face-to-face group. }\end{array}$ \\
\hline
\end{tabular}

\section{Patient attendance}

Dorstyn et Treatment al (2013, ethnic minorities) [21]

Chris- Treatment tensen et al (2019, older adults) [25]

Lin et al Treatment (2019) [30]
Depression Telephone CBT $(\mathrm{n}=2)$; telephone supportive counseling $(\mathrm{n}=1)$; telephone structural ecosystems therapy $(n=1)$; internet-based CBT with weekly individual sessions $(\mathrm{n}=2)$; internet telepsychiatry $(\mathrm{n}=1)$; internet supportive counseling and personalized email correspondence $(n=1)$

Depression Video consultations or a range for telepsychiatry of diag- $\quad(n=21)$

noses including depression

Substance use disorders

Video- or telephonebased psychotherapy $(n=10)$; remote medi-
Face-to-face $(\mathrm{n}=1)$; treatment as usual $(n=3)$; minimal support control or waitlist $(\mathrm{n}=2)$; no control $(\mathrm{n}=2)$

Face-to-face (11), no control (10) cation management $(n=3$; patient presents at local clinic with nurse and are connected to a physician at a distant site via videoconference)
Face-to-face psychotherapy $(\mathrm{n}=7)$; telephone $(n=2)$; treatment as usual $(\mathrm{n}=1)$; no control $(\mathrm{n}=3)$
One study reported difficulty reaching participants by telephone resulting in fewer sessions completed.
Video consultations increased access to care and removed barriers such as having to travel $(n=4)$.

Most studies reported increased retention in telemental health groups $(n=4)$; however, no difference in in number of sessions attended was sometimes reported $(n=2)$. One alcohol addiction study reported lower dropout in the telemental health group, and more patients in this group were still in treatment at 6 months and one year. Two opioid addiction studies found that videoconference interventions resulted in a better retention of participants up to one year as compared with those receiving in-person care. Another opioid study found $>50 \%$ retention at 12 weeks but did not have a comparison group. However, another two studies found no difference between videoconference-delivered psychotherapy and in-person psychotherapy in the number of sessions attended. 


\begin{tabular}{|c|c|c|c|c|c|c|}
\hline Outcome & Study & $\begin{array}{l}\text { Assessment } \\
\text { or treatment }\end{array}$ & $\begin{array}{l}\text { Main diag- } \\
\text { nosis }\end{array}$ & $\begin{array}{l}\text { Intervention (number } \\
\text { of studies) }\end{array}$ & $\begin{array}{l}\text { Comparator (number } \\
\text { of studies) }\end{array}$ & Results \\
\hline & $\begin{array}{l}\text { Turgoose } \\
\text { et al ( } 2018 \\
\text { veterans) } \\
{[38]}\end{array}$ & Treatment & PTSD & $\begin{array}{l}\text { Video-based exposure } \\
(\mathrm{n}=10) \text {; video-based } \\
\text { cognitive processing } \\
\text { therapy }(\mathrm{n}=6) \text {; video- } \\
\text { based CBT }(\mathrm{n}=5) \text {; } \\
\text { mixed interventions } \\
(\mathrm{n}=11) \text {; telephone } \\
\text { mindfulness }(\mathrm{n}=1) \text {; } \\
\text { video-based behav- } \\
\text { ioral activation }(\mathrm{n}=2) \text {; } \\
\text { video-based eye } \\
\text { movement desensitiza- } \\
\text { tion and reprocessing } \\
(\mathrm{n}=1) \text {; video-based } \\
\text { anger management } \\
(\mathrm{n}=2) ; \text { video-based } \\
\text { general coping and } \\
\text { psychoeducation inter- } \\
\text { ventions ( } \mathrm{n}=3 \text { ) }\end{array}$ & Face-to-face $(n=41)$ & $\begin{array}{l}\text { In the majority of cases, there were no differ- } \\
\text { ences between teletherapy and in-person } \\
\text { treatments on dropout or attendance. There } \\
\text { was some indication that teletherapy may } \\
\text { help to increase uptake. }\end{array}$ \\
\hline
\end{tabular}

Safety

Bolton and Treatment PTSD
Dorstyn
(2015) [24]

Turgoose Treatment PTSD et al (2018, veterans) [38]

\section{Technical difficulties}

Bolton and Treatment

(2015) [24]

Chris Treatment tensen et al (2019, older adults) [25]
PTSD

Internet-based CBT with therapist support via telephone calls, introductory face-toface meetings, or emails $(n=6)$; videobased CBT $(\mathrm{n}=5)$

Depression Video consultations or a range for telepsychiatry of diagnoses including depression
Face-to-face $(\mathrm{n}=5)$; $\quad$ Minimal technical difficulties were encounsupportive counseling tered $(\mathrm{n}=1)$; participants reported that they $(\mathrm{n}=1)$; waitlist $(\mathrm{n}=1)$; would have preferred different forms of meno control $(n=4) \quad$ dia, for example, a mobile app, to supplement support $(\mathrm{n}=1)$.

Face-to-face (11), no control (10)

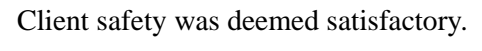

There might be some occasions where veterans have concerns about exposure tasks due to the lack of physical presence of the therapist; however, overall, it was established that these can be used just as effectively remotely. If appropriate steps are taken to manage safety, then episodes of acute suicidality can also be managed. 


\begin{tabular}{|c|c|c|c|c|c|c|}
\hline Outcome & Study & $\begin{array}{l}\text { Assessment } \\
\text { or treatment }\end{array}$ & $\begin{array}{l}\text { Main diag- } \\
\text { nosis }\end{array}$ & $\begin{array}{l}\text { Intervention (number } \\
\text { of studies) }\end{array}$ & $\begin{array}{l}\text { Comparator (number } \\
\text { of studies) }\end{array}$ & Results \\
\hline & $\begin{array}{l}\text { Turgoose } \\
\text { et al }(2018, \\
\text { veterans }) \\
{[38]}\end{array}$ & Treatment & PTSD & $\begin{array}{l}\text { Video-based exposure } \\
(\mathrm{n}=10) \text {; video-based } \\
\text { cognitive processing } \\
\text { therapy }(\mathrm{n}=6) \text {; video- } \\
\text { based CBT }(\mathrm{n}=5) ; \\
\text { mixed interventions } \\
(\mathrm{n}=11) \text {; telephone } \\
\text { mindfulness }(\mathrm{n}=1) ; \\
\text { video-based behav- } \\
\text { ioral activation }(\mathrm{n}=2) ; \\
\text { video-based eye } \\
\text { movement desensitiza- } \\
\text { tion and reprocessing } \\
(\mathrm{n}=1) \text {; video-based } \\
\text { anger management } \\
(\mathrm{n}=2) ; \text { video-based } \\
\text { general coping and } \\
\text { psychoeducation inter- } \\
\text { ventions ( } \mathrm{n}=3 \text { ) }\end{array}$ & Face-to-face $(n=41)$ & $\begin{array}{l}\text { Commonly reported technical difficulties } \\
\text { were low-image resolution on videoconfer- } \\
\text { encing technology, not being able to connect, } \\
\text { and audio delays. }\end{array}$ \\
\hline
\end{tabular}

${ }^{\mathrm{a} P T S D}$ : posttraumatic stress disorder.

${ }^{\mathrm{b}} \mathrm{CBT}$ : cognitive behavioral therapy.

\section{Acceptability Outcomes}

\section{Overview}

Acceptability outcomes were reported in 10 reviews [20,21,24,25,28-31,34,38]. Relevant outcomes included clinician satisfaction $(n=5)[20,28,29,31,38]$, therapeutic alliance $(n=6)$ [24,25,30,31,34,38], patient satisfaction $(n=7)$ [21,25,28-31,38], and convenience $(n=3)[25,30,31]$.

\section{Clinician Satisfaction}

Overall, clinicians tend to report a preference for face-to-face interventions for both assessment and treatment [28,29]. However, some reviews have reported that clinicians find video-based therapies to be acceptable $[29,38]$. One review of remote interventions for the carers of people with dementia found that counselors felt they might need more support via debriefing following remote counseling sessions. They also reported problems when the reactions of carers could not be ascertained via remote technology along with the feelings of helplessness due to the impersonal nature of remote technology [31]. Health care providers using remote interventions in older adults noted the practical benefits of telehealth [20].

\section{Therapeutic Alliance}

Overall, therapeutic alliances were reported to be comparable with face-to-face interventions. However, some patient groups were found to feel more comfortable talking to therapists face to face, if possible, such as older female adults [25] or veterans [38]. A meta-analysis was conducted in one review, which found that although standardized mean differences in alliance ratings were not significantly different, the lower limit of the $95 \%$ CI fell outside the prespecified limit of noninferiority, indicating that videoconference interventions may be inferior to face-to-face treatment, likely the result of therapist-rated (but not patient-rated) alliance scores being lower in the videoconference groups [34].

\section{Patient Satisfaction}

High patient satisfaction was generally reported across seven reviews, and patients tended to find remote interventions as satisfactory as face-to-face alternatives. This was true in substance use disorders [30], depression [21,25,28,29], PTSD [38], older adults [25], ethnic minorities [21], and carers of patient populations with dementia [31]; however, Hassan and Sharif [29] reported a few studies indicating preference for face-to-face interventions. A review of older people noted that initial skepticism between both service users and providers tended to dissipate following positive experiences of videoconferencing; moreover, with appropriate support and access to technology, patients who had not previously used computers reported positive experiences of video calls [25]. Accepting the need for treatment to be in teletherapy form instead of face-to-face therapy was reported as important in a study of veterans with PTSD [38].

\section{Convenience}

Patients reported the benefits of added convenience of therapy sessions at home via remote interventions for both depression $[25,31]$ and substance use disorders [30]. Table 4 presents further details on the acceptability outcomes. 
Table 4. Acceptability outcomes.

\begin{tabular}{|c|c|c|c|c|c|c|}
\hline $\begin{array}{l}\text { Out- } \\
\text { come }\end{array}$ & Study & $\begin{array}{l}\text { Assessment } \\
\text { or treatment }\end{array}$ & $\begin{array}{l}\text { Main diagno- } \\
\text { sis }\end{array}$ & Intervention (number of studies) & $\begin{array}{l}\text { Comparator } \\
\text { (number of stud- } \\
\text { ies) }\end{array}$ & Results \\
\hline
\end{tabular}

\section{Clinician satisfaction}

$\begin{array}{ll}\text { Garcia-Lizana } & \text { Assessment } \\ \text { and Munoiz- } & \text { and treat- } \\ \text { Mayorga } & \text { ment } \\ (2010)[28] & \end{array}$

(2010) [28]

$\begin{array}{lll}\text { Hassan and } & \text { Assessment } & \text { Multiple } \\ \text { Sharif (2019; } & \text { and treat- } & \\ \text { refugee popu- } & \text { ment } & \\ \text { lations) [29] } & & \end{array}$

lations) [29]

Turgoose et al Treatment (2018; veterans) [38]

Harerimana et Treatment al (2019; older adults) [20]
Videoconferencing for diagnosis and

(2014) [31] Support for carers of people with dementia (depressive symptoms)

\section{Therapeutic alliance}

Bolton and Treatment Dorstyn (2015) [24]

Christensen et Treatment al (2019, older adults) [25] follow-up ( $n=3)$; video-based evaluation of competency to stand trial $(n=1)$; nonspecific video-based CBT $^{\mathrm{a}}(\mathrm{n}=5)$; videobased psychoeducation and counseling $(n=1)$

Not specified videoconferencing treatment intervention $(n=2)$; video-based CBT ( $n=7)$; video-based psychoeducation $(n=2)$; video-based relapse prevention $(n=1)$; video-based treatment management $(\mathrm{n}=1)$; video-based evaluation of competency to stand trial $(n=1)$

Video-based exposure $(\mathrm{n}=10)$; videobased cognitive processing therapy ( $n=6)$; video-based CBT $(n=5)$; mixed interventions $(\mathrm{n}=11)$; telephone mindfulness $(n=1)$; video-based behavioral activation $(n=2)$; video-based eye movement desensitization and reprocessing $(n=1)$; video-based anger management $(n=2)$; video-based general coping and psychoeducation interventions $(n=3)$

Depression

Telephone based $(n=6)$; video based $(n=2)$; web based $(n=1)$

Waiting list $\left(\mathrm{NR}^{\mathrm{c}}\right)$; treatment as usual (NR)

Friendly calls $(n=3)$; treatment as usual $(\mathrm{n}=6)$ people with ing implementation outcomes) (for depressive symptoms)

Face-to-face $(\mathrm{n}=10)$

Face-to-face $(n=14)$

Face-to-face $(\mathrm{n}=41)$

Friendly calls
$(n=3) ;$ treatment
as usual $(n=6)$
positive perceptions and notice practical benefits associated with the use of telehealth for delivery of community mental health care $(n=1)$. However, nurses of a telepsychiatry consultation generally did not rate it positively $(n=1)$.

Spatial distance could be a problem because counselors cannot see the reactions of carers $(n=1)$. Counselors also expressed a need for a debriefing with colleagues after counseling sessions.

Internet-based CBT with therapist support via telephone calls, introductory face-to-face meetings, or emails $(n=6)$; video-based CBT $(\mathrm{n}=5)$

Depression Video consultations for telepsychiatry or a range of $\quad(n=21)$ diagnoses including depression
Face-to-face $(\mathrm{n}=5)$; supportive counseling $(\mathrm{n}=1)$; waitlist $(\mathrm{n}=1)$; no control $(n=4)$

Face-to-face (11), Video sessions were considno control (10)

Good therapeutic alliance reported $(n=5)$ ered better than telephone sessions because of their similarity to face-to-face sessions $(n=2)$; however, in one study, female patients found videoconferencing interventions more impersonal than face-toface sessions. One clinician reported reduced communication intensity because of less clear facial movements $(n=1)$. 


\begin{tabular}{|c|c|c|c|c|}
\hline $\begin{array}{l}\text { Out- } \\
\text { come }\end{array}$ & Study & $\begin{array}{l}\text { Assessment } \\
\text { or treatment }\end{array}$ & $\begin{array}{l}\text { Main diagno- } \\
\text { sis }\end{array}$ & Intervention (number of studies) \\
\hline & $\begin{array}{l}\text { Lin et al } \\
(2019)[30]\end{array}$ & Treatment & $\begin{array}{l}\text { Substance } \\
\text { use disorders }\end{array}$ & $\begin{array}{l}\text { Video- or telephone-based psychothera- } \\
\text { py }(n=10) \text {; remote medication manage- } \\
\text { ment }(n=3 \text {; patient presents at local clinic } \\
\text { with nurse and are connected to a physi- } \\
\text { cian at a distant site via videoconference) }\end{array}$ \\
\hline & $\begin{array}{l}\text { Lins et al } \\
(2014)[31]\end{array}$ & $\begin{array}{l}\text { Support for } \\
\text { carers of } \\
\text { people with } \\
\text { dementia } \\
\text { (depressive } \\
\text { symptoms) }\end{array}$ & $\begin{array}{l}\text { Carers of } \\
\text { people with } \\
\text { dementia } \\
\text { (for depres- } \\
\text { sive symp- } \\
\text { toms) }\end{array}$ & $\begin{array}{l}\text { Telephone counseling ( } \mathrm{n}=2 \text { reporting } \\
\text { implementation outcomes) }\end{array}$ \\
\hline & $\begin{array}{l}\text { Norwood et al } \\
\text { (2018) [34] }\end{array}$ & Treatment & Multiple & Video-based CBT $(\mathrm{n}=10)$ \\
\hline
\end{tabular}

Comparator Results

(number of stud-

ies) (2018) [34] trol $(n=3)$
Face-to-face psy- Participant and therapist ratchotherapy $(n=7) ; \quad$ ings of therapeutic alliance telephone $(n=2) ; \quad$ ratings were high in both treatment as usu- videoconference and in-peral $(n=1)$; no con- son interventions $(n=1)$.

Friendly calls Counselors can feel frustrated $(n=3)$; treatment and helpless during telephone as usual $(n=6) \quad$ counseling because it is relatively impersonal $(n=1)$.

Face-to-face CBT Six studies used a face-to-face $(\mathrm{n}=10) \quad$ condition as a control group, with four finding that therapeutic alliance was noninferior in the videoconferencing condition as compared with face-to-face conditions. The remaining two reported that alliance was higher in the face-to-face group, though one reported no difference in participant rated alliance, only significantly higher therapistrated alliance for the face-toface group. Standardized mean difference in alliance ratings $-0.30(95 \% \mathrm{CI}-0.67$ to 0.07$), P=.11, \mathrm{n}=4$. The lower limit of the $95 \%$ CI fell outside the prespecified limit of noninferiority (Cohen $d=-0.50$ ), indicating that with respect to working alliance, videoconference interventions were inferior to face-to-face treatment.

Turgoose et al Treatment

Video-based exposure $(\mathrm{n}=10)$; videobased cognitive processing therapy

Face-to-face $(\mathrm{n}=6)$; video-based CBT $(\mathrm{n}=5)$; mixed interventions $(\mathrm{n}=11)$; telephone mindfulness $(\mathrm{n}=1)$; video-based behavioral activation $(\mathrm{n}=2)$; video-based eye movement desensitization and reprocessing $(n=1)$; video-based anger management $(\mathrm{n}=2)$; video-based general coping and psychoeducation interventions $(n=3)$ 


\begin{tabular}{lllll}
\hline $\begin{array}{l}\text { Out- } \\
\text { come }\end{array}$ & Study & $\begin{array}{l}\text { Assessment } \\
\text { or treatment }\end{array}$ & $\begin{array}{l}\text { Main diagno- } \\
\text { sis }\end{array}$ & Intervention (number of studies) \\
\hline & $\begin{array}{l}\text { Christensen et } \\
\text { al (2019; older } \\
\text { adults) [25] }\end{array}$ & Treatment & $\begin{array}{l}\text { Depression } \\
\text { or a range of } \\
\text { diagnoses in- } \\
\text { cluding de- } \\
\text { pression }\end{array}$ & $\begin{array}{l}\text { Video consultations for telepsychiatry } \\
(\mathrm{n}=21)\end{array}$ \\
&
\end{tabular}

Dorstyn et al (2013, ethnic minorities) [21]

Garcia-Lizana (2010) [28]

Assessment and treatment
Treatment

Depression

Multiple

(2)

Hassan and Sharif (2019; refugee populations) [29]
Lins et al (2014) [31]

\section{Assessment Multiple} and treatment Support for carers of people with dementia (depressive symptoms)

Carers of dementia toms)
Telephone CBT $(\mathrm{n}=2)$; telephone supportive counseling $(n=1)$; telephone structural ecosystems therapy $(\mathrm{n}=1)$; internetbased CBT with weekly individual sessions $(\mathrm{n}=2)$; internet telepsychiatry $(\mathrm{n}=1)$; internet supportive counseling and personalized email correspondence $(\mathrm{n}=1)$

Videoconferencing for diagnosis and follow-up ( $n=3)$; video-based evaluation of competency to stand trial $(n=1)$; nonspecific video-based CBT ( $\mathrm{n}=5$ ); videobased psychoeducation and counseling $(\mathrm{n}=1)$

Not specified videoconferencing treatment intervention $(\mathrm{n}=2)$; video-based CBT ( $\mathrm{n}=7$ ); video-based psychoeducation $(n=2)$; video-based relapse prevention $(\mathrm{n}=1)$; video-based treatment management $(\mathrm{n}=1)$; video-based evaluation of competency to stand trial $(n=1)$

Substance use disorders py $(n=10)$; remote medication management $(n=3$; patient presents at local clinic with nurse and are connected to a physician at a distant site via videoconference) people with (for depressive symp-

Telephone counseling ( $n=9, n=2$ reporting implementation outcomes)
Video- or telephone-based psychothera-
Comparator

Results

(number of stud-

ies)

Face-to-face (11), High levels of patient satisfacno control (10) tion and acceptability were frequently reported, and there were no significant differences between face-to-face and videoconferencing in $\mathrm{RCT}^{\mathrm{d}}$ studies. Patients preferred the reduced waiting time $(\mathrm{n}=1)$. Some patients reported initial skepticism as a reason for preference of faceto-face interventions, however this usually dissipated with use of remote technology.

Face-to-face $(n=1)$; treatment as usual $(n=3)$; minimal support control or waitlist $(n=2)$; no control $(n=2)$

Face-to-face $(n=10)$

Consistent patient satisfaction was reported.

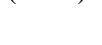

Face-to-face $(\mathrm{n}=14)$ $\mathrm{n}=3)$, treatment as usual $(\mathrm{n}=6)$

Face-to-face psychotherapy $(n=7)$; telephone $(n=2)$; treatment as usual $(n=1)$; no control $(n=3)$

Patients generally appeared satisfied with the technology utilized and its quality $(n=2)$. High satisfaction was reported in other studies; however, it is unclear if satisfaction was generated by the program or the technology $(n=5)$.

Most studies reported a high satisfaction with videoconference interventions $(n=3)$ or no difference in satisfaction as compared with face-to-face groups $(n=3)$; however, one study reported a lower satisfaction as compared with face-toface sessions.

Satisfaction was generally quite high in videoconference interventions and that participants would recommend the intervention to others.

Reservations expressed about getting advice from an unknown person $(\mathrm{n}=1)$. Both studies reported that carers found the information given helpful and were grateful for it. One study found that telephone counseling helped alleviate loneliness in carers. 


\begin{tabular}{|c|c|c|c|c|c|c|}
\hline $\begin{array}{l}\text { Out- } \\
\text { come }\end{array}$ & Study & $\begin{array}{l}\text { Assessment } \\
\text { or treatment }\end{array}$ & $\begin{array}{l}\text { Main diagno- } \\
\text { sis }\end{array}$ & Intervention (number of studies) & $\begin{array}{l}\text { Comparator } \\
\text { (number of stud- } \\
\text { ies) }\end{array}$ & Results \\
\hline
\end{tabular}
video-based anger management $(n=2)$; video-based general coping and psychoeducation interventions $(n=3)$

\section{Convenience}

\begin{tabular}{|c|c|c|c|c|c|}
\hline $\begin{array}{l}\text { Christensen et } \\
\text { al (2019; older } \\
\text { adults) [25] }\end{array}$ & Treatment & $\begin{array}{l}\text { Depression } \\
\text { or a range of } \\
\text { diagnoses in- } \\
\text { cluding de- } \\
\text { pression }\end{array}$ & $\begin{array}{l}\text { Video consultations for telepsychiatry } \\
(n=21)\end{array}$ & $\begin{array}{l}\text { Face-to-face }(11), \\
\text { no control (10) }\end{array}$ & $\begin{array}{l}\text { Patients reported that video } \\
\text { consultations were more relax- } \\
\text { ing, and it was convenient to } \\
\text { stay at home }(n=3) \text {. }\end{array}$ \\
\hline $\begin{array}{l}\text { Lin et al } \\
(2019)[30]\end{array}$ & Treatment & $\begin{array}{l}\text { Substance } \\
\text { use disorders }\end{array}$ & $\begin{array}{l}\text { Video or telephone-based Psychotherapy } \\
(\mathrm{n}=10) \text { remote medication management } \\
(\mathrm{n}=3 \text {; patient presents at local clinic with } \\
\text { nurse and are connected to a physician } \\
\text { at a distant site via videoconference) }\end{array}$ & $\begin{array}{l}\text { Face-to-face psy- } \\
\text { chotherapy }(n=7) \text {; } \\
\text { telephone }(n=2) ; \\
\text { treatment as usu- } \\
\text { al }(n=1) ; \text { no con- } \\
\text { trol }(n=3)\end{array}$ & $\begin{array}{l}\text { Participants found the in- } \\
\text { creased convenience impor- } \\
\text { tant as they would have had } \\
\text { difficulty obtaining the inter- } \\
\text { vention without telemental } \\
\text { health }(n=1) \text {. }\end{array}$ \\
\hline $\begin{array}{l}\text { Lins et al } \\
(2014)[31]\end{array}$ & $\begin{array}{l}\text { Support for } \\
\text { carers of } \\
\text { people with } \\
\text { dementia } \\
\text { (depressive } \\
\text { symptoms) }\end{array}$ & $\begin{array}{l}\text { Carers of } \\
\text { people with } \\
\text { dementia } \\
\text { (for depres- } \\
\text { sive symp- } \\
\text { toms) }\end{array}$ & $\begin{array}{l}\text { Telephone counseling }(\mathrm{n}=9, \mathrm{n}=2 \text { report- } \\
\text { ing implementation outcomes })\end{array}$ & $\begin{array}{l}\text { Friendly calls } \\
(n=3) \text {; treatment } \\
\text { as usual }(n=6)\end{array}$ & $\begin{array}{l}\text { Carers found telephone coun- } \\
\text { seling good because it avoid- } \\
\text { ed the stress involved in coor- } \\
\text { dinating an appointment } \\
(n=1) \text {. Needs for } 24 \text {-hour } \\
\text { counselor availability }(n=1) \text {. }\end{array}$ \\
\hline
\end{tabular}

${ }^{\mathrm{a}} \mathrm{CBT}$ : cognitive behavioral therapy.

${ }^{b}$ PTSD: posttraumatic stress disorder.

${ }^{\mathrm{c}} \mathrm{NR}$ : not recorded.

${ }^{\mathrm{d}} \mathrm{RCT}$ : randomized controlled trial.

\section{Cost-Effectiveness}

A total of 2 reviews presented conclusions regarding the economic impact of telepsychiatry [29,33]. One review concluded that telepsychiatry can be cost-effective as compared with face-to-face interventions, particularly in rural areas where there were lower numbers of consultations required before telepsychiatry becomes more cost-effective (combatting initial equipment costs) [29]. The second review, in which the focus was on the cost-effectiveness of telepsychiatry, reported that $60 \%(15 / 25)$ of the included studies found telepsychiatry programs to be less expensive than standard in-person care, due to savings such as the travel time and reduced need for patients and their families to take time off work. However, the remaining studies included in the review concluded that telepsychiatry programs were more expensive, particularly because of videoconferencing equipment costs $(n=8)$ or found no difference in costs $(n=1)$. The review also found a large range in reported costs, with, for example, a long-term delivery of telepsychiatry for veterans ranging from US \$930 to US \$2116 per patient. The cost-effectiveness analyses within the review suggested that telepsychiatry was less cost-effective than face-to-face alternatives. Accordingly, the review concluded that variation was due to a large disparity in the reporting of costs, for example, whether personnel costs or initial equipment costs were included, and that there remains a need for future efforts to determine the cost-effectiveness of different forms of telepsychiatry, particularly for different disorders and applications of remote technology (eg, consultation vs therapy). In addition, a third review [21] examined health service utilization, which impacts cost-effectiveness. They found that the rates of antidepressant and health service utilization were similar in the 3 months following both telephone and web-based counseling as compared with usual care or face-to-face controls.

\section{Guidelines}

Only one review [37] of guidelines for telemental health met the inclusion criteria. This review comprehensively summarizes the guidance published to date, including guidance on decisions about the appropriateness of e-mental health, ensuring the competence of mental health professionals, legal and regulatory issues, confidentiality, professional boundaries, and crisis intervention. Recommendations from 19 guidelines were characterized as either firm (50\% or more of the guidelines recommended this) or tentative (fewer than $50 \%$ of the guidelines recommended this). The review identified the following as firm recommendations: ensuring that the remote interventions were appropriate for the needs of individual 
patients and within the boundaries of therapist competence, as well as adhering to laws and regulations; maintaining confidentiality and seeking informed consent (including for specific aspects of remote appointments such as data security); and ensuring that geographically accessible in-person clinical support is available in the case of a crisis or emergency. Guidelines suggested a higher risk of harm for people with cognitive impairments and psychotic disorders but did not provide stronger recommendations on how to adapt delivery to these populations. Furthermore, a minority of guidelines discussed remote technology in young people, with the main message being the importance of checking consent with both the patient and parent. A full summary of the recommendations from the review can be found in Multimedia Appendix 5.

\section{Discussion}

\section{Principal Findings}

Our umbrella review retrieved a variety of recent relevant systematic reviews on which the future planning of telemental health implementation can be usefully drawn. Across the 19 reviews included in this umbrella review, the results suggest that the remote forms of assessment and intervention can produce at least moderate decreases in symptom severity for people affected by a variety of mental health conditions. Arguments are strongest for videoconferencing interventions, with multiple reviews concluding that outcomes appear comparable with face-to-face interventions at the end of treatment. However, at present, conclusions regarding longer-term results remain uncertain, whereas some reviews have reported the maintenance of positive effects up to six months for both videoconference- and telephone-based interventions, other reviews have suggested that effects are less long-lasting than for face-to-face interventions and the amount of evidence on which to base this assessment is limited. An avenue for future research could be to further examine possible differences between settings in which longer-term benefits have been found compared with those which did not find this.

Reviews also suggest that remote interventions are acceptable to service users participating in studies who tend to report being as satisfied as in face-to-face interventions. This, along with reports that participants adhere to telemental health-based interventions at similar rates to face-to-face interventions, is promising with respect to adaptations during the COVID-19 crisis and for the future, but the reviews tend to relate to small-scale and carefully planned implementations of telemental health with volunteer participants, rather than to large-scale emergency implementations, as in the current crisis. Conclusions drawn from the reviews regarding specific factors that could impact patient satisfaction should also be noted. For example, a report of reduced skepticism following positive experiences [25], if confirmed, suggests that induction sessions and other methods of familiarizing patients with technology and making it accessible to them may improve acceptability and uptake. Clinician satisfaction varied more with reviews tending to conclude that although remote interventions may be acceptable, clinicians usually prefer face-to-face interventions. This may be related to the reports in some reviews that the clinician ratings of therapeutic alliance are poorer with telemental health [34,277]. Despite this, patients tend to feel that the alliance is on par with face-to-face interventions $[30,34,38]$. There is some suggestion that training and more experience with video and telephone-based technology for intervention delivery may alleviate this concern among therapists [277]; however, staff reports following an increased uptake in the COVID crisis appear to suggest continued concerns about rapport [2]. In the future, a thorough exploration of the exact reasons for acceptability and adherence would benefit the evidence base, for example, certain contextual factors such as appointment type, mood, and time of day may have a substantial influence on patient satisfaction and should be explored further.

Evidence yielded by reviews on the important questions of whether assessments appeared accurate and comprehensive and whether treatment was delivered as intended was limited. A total of 2 reviews examined the comparability of remote versus face-to-face assessment, with one review finding a good correlation between assessments and another finding that there was insufficient high-quality evidence published thus far to draw accurate and meaningful conclusions [27,32]. Regarding fidelity, we found one review that reported good therapist fidelity and competence in remotely delivered interventions in the context of service delivery for veterans with PTSD [38], but systematic reviews do not appear to yield evidence as to whether high fidelity and quality is achieved with telemental health interventions. Standardized training rooted in evidence will be important in ensuring high-quality intervention delivery and overcoming self-doubt among clinicians in delivering remote interventions [37,277,278].

A crucial question regarding the rapid adoption of remote technologies during the pandemic has been whether service users may drop out of or be excluded from care as a result. A minority of the reviews included relevant data, most of which were relatively reassuring. Reviews reported that remote interventions were convenient and that examining uptake reported an increase. When examined, retention was also comparable with face-to-face treatment [30,38]. Reports of technological difficulties were reassuringly few across reviews, although this may be more easily achieved with well-planned, smaller-scale implementations of telemental health that characterize research studies than with larger-scale implementation. However, one aspect of remote delivery on which reviews did not generally report is the risk of complete digital exclusion for patients who may not have the skills or resources to engage with remote therapy or assessments $[1,2]$. The implementation of telemental health across service systems is only likely to be beneficial if there are clear plans to prevent patients with limited access to technology from being at a disadvantage $[279,280]$, whether by supporting them to engage with remote care or ensuring that equivalent care is available face-to-face.

Digital exclusion may result in the exacerbation of existing inequalities where already disadvantaged groups, such as older adults, people with sensory or cognitive impairment, or members of some BAME groups are at a greater risk of exclusion $[1,9,281]$. Some reviews have examined this issue [20,25]. A single review by Dorstyn et al [21] reported that members of 
predominantly North American ethnic minority communities with depression benefited from telecounseling. A more substantial evidence base is thus urgently required to evaluate the risk of exacerbating ethnic inequalities in mental health care access through telemental health adoption. Furthermore, many have argued that the shift to remote working may exclude older adults [25,281]. On the basis of one review [20] suggesting that videoconferencing interventions can be comparable with face-to-face sessions, and another review [25] finding high levels of patient satisfaction, therapeutic alliance, attendance, and convenience, this review suggests that effective remote intervention delivery may be feasible for older adults. This is encouraging as staying at home and avoiding infection during the pandemic is especially desirable for older adults. No reviews were found regarding other subgroups of potential concern, such as people with sensory or cognitive impairments, children and adolescents and their families, or people with comorbid mental and physical health conditions. We also did not find substantial evidence on settings of particular interest, such as mental health inpatient services (including the use of telemental health in compulsory detention processes) and crisis services.

\section{Limitations}

The findings of this umbrella review should be considered along with a number of limitations. First, umbrella reviews aim to present an overview of findings from systematic reviews [282], making conclusions reliant on the quality and accuracy of reporting of included reviews and necessarily resulting in some loss of nuance when findings are pooled. For example, information regarding follow-up periods was not always clear in the conclusions presented in reviews, making a thorough examination of the longevity of benefits difficult. Although we included only reviews considered to be systematic (defined here as searching at least three databases and conducting a quality assessment when synthesizing quantitative data), it was apparent from our quality assessment that the majority of reviews lacked several attributes or characteristics of a high-quality review with robust conclusions, such as prespecified protocols and duplicate study selection. However, our aim was to gain a rapid overview, especially relevant to the current and future rapid implementation of telemental health, of the extent of supporting evidence available in previous literature regarding telemental health: the umbrella review method provides a useful route to achieving this. The inclusion of systematic reviews focused on methods other than randomized controlled trials and on guidance further increases the methodological variability of included reviews and studies, but it is a choice we have made to maximize the retrieval of material from which real-world important lessons can be learned regarding feasibility, acceptability, and implementation barriers and facilitators [283].

This review also aimed to summarize the outcomes related to the cost-effectiveness of remote delivery. We found only two reviews that summarized this outcome and only one that did so comprehensively. It is important that further work should be done to establish the cost-effectiveness of different forms of telemental health, for different patient groups, but there is a significant gap in the literature, despite efficiency being presented as one of the arguments made to support remote interventions [284].

Finally, this review aimed to summarize the literature published before the COVID-19 pandemic to identify evidence relevant to the current context and the recovery from the pandemic. However, the pandemic has given rise to a much more extensive switch to telemental health than previously, meaning that not all conclusions may be generalized to the new normal. In particular, the evidence retrieved in this review tends not to relate to the implementation of telemental health across whole catchment areas and does not yield much evidence relevant to currently highly salient issues such as risks of digital exclusion or exacerbation of mental health inequalities and economic disadvantage, which may well be exacerbated as a result of COVID-19 [1,2]. The conclusions of this review should be supplemented with the further scrutiny of the adoption of telemental health within the context of these societal changes, for example through discussion with people with lived experience (Textbox 1). 
Textbox 1. Lived experience commentary.

\begin{abstract}
Lived Experience Commentary (by SM From South London Applied Research Collaboration)
As a somewhat long-term user of remote working to access assessment and treatment for a mental disorder, I found it fascinating to read this umbrella review. My experience of remote working has unsurprisingly arisen out of the spatial distancing restrictions imposed upon us all as a result of the SARS-CoV2 outbreak. No surprises there!

My personal experience has been, that although remote working is better than nothing, it isn't in general as good as face-to-face working. Through my patient and public involvement work within my local Trust, I am aware that many fellow patients and carers are also of this view; remote working is okay as an interim measure, but could never replace the therapeutic alliance that can be achieved through sharing space as well as thoughts, feelings, and experiences.

I found it very interesting that the umbrella review found that, in general, clinicians have concerns about remote working as the vast majority of clinicians who I have liaised with via nonlocal advisory groups and PPI have voiced the opinion that they prefer assessing and delivering talking therapy remotely as they find it quicker and more efficient and means they don't have to waste time traveling to different venues. This is understandable; however, for patients who have never met a clinical assessor or therapist before, it can be somewhat alienating to consult with a voice over a phone or an image on a smartphone rather than a present living breathing human being.

One of the main questions which came to mind as I read through the umbrella review was whether it was clarified in any of the individual reviews what service users meant or interpreted remote interventions being satisfactory or acceptable; better than nothing, okay, fine, what? It would have been useful to clarify this.

Another interesting point was that "reports of technological difficulties were reassuringly few across reviews." Maybe it's just me, but I have experienced regular and sometimes quite disastrous "technological difficulties," being locked out of virtual meetings, poor audio and visual reception, loss of signal, not being able to access Wi-Fi, etc. This isn't just annoying but can be incredibly frustrating if you are relying on a therapy session to help you to manage difficult matters in your life, including the mass COVID-19 related isolation and loneliness.

Regarding guidelines for remote working, I am glad that the umbrella review highlighted the gap in guideline provision for remote working with young people. A child psychiatrist I know well has found it very frustrating to have to rely on remote means of assessing young patients and has deep concerns about various risk and safety issues.

Overall, I think the umbrella review raises many pertinent questions and issues, and I hope that at some time in the future, there will be another review of the research literature that will begin in time to proliferate with regard to peoples' experiences of using remote mental health assessments and interventions during this time of COVID-19.
\end{abstract}

\section{Conclusions}

The research across a range of mental health conditions suggests that telemental health is potentially an effective, feasible, and acceptable tool for providing mental health treatment, at least when interventions are relatively well-designed and well-planned, as has been the case in research studies. Comparability in terms of symptom improvement and satisfaction relative to face-to-face methods suggests the move to telemental health to sustain mental health services during the pandemic has been a reasonable one; however, the context of this emergency implementation has been very different from most research studies. Further research should seek to build on existing evidence for establishing the long-term effectiveness and cost-effectiveness of telemental health in a range of groups and settings, such as including children and young people and inpatient acute services and focusing on issues of inclusion and reach. A further question on which further evidence would be highly desirable is the extent to which digital exclusion can be remedied, including the examination of interventions designed to include those with limited previous digital resources or skills. Future planning for telemental health implementation should draw on previous research evidence, often acquired in relatively small-scale studies, and on experiences of trying to engage large service user populations and most of the mental health workforce with remote technology delivery during the COVID-19 pandemic.

\title{
Acknowledgments
}

This paper presents independent research commissioned and funded by the National Institute for Health Research (NIHR) Policy Research Programme conducted by the NIHR Policy Research Unit in Mental Health. The views expressed are those of the authors and not necessarily those of the NIHR, the Department of Health and Social Care or its arm's length bodies, or other government departments.

This study was supported by the NIHR Applied Research Collaboration (ARC) South London at King's College Hospital National Health Service (NHS) Foundation Trust. The views expressed are those of the authors and not necessarily those of the NIHR or the Department of Health and Social Care.

LG is funded by King's Improvement Science, which is part of the NIHR ARC South London and comprises a specialist team of improvement scientists and senior researchers based at King's College London. King's Improvement Science is funded by King's Health Partners (Guy's and St Thomas' NHS Foundation Trust, King's College Hospital NHS Foundation Trust, King's College London, and South London and Maudsley NHS Foundation Trust), Guy's and St Thomas' Charity, and Maudsley Charity. JW is funded by the Maudsley Charity. FG is in part supported by the NIHR's Biomedical Research Centre at South London and 
Maudsley NHS Foundation Trust and King's College London, the Maudsley Charity, and NIHR ARC South London at King's College Hospital NHS Foundation Trust.

\section{Conflicts of Interest}

None declared.

\section{Multimedia Appendix 1}

Search strategy.

[DOCX File, 29 KB-Multimedia Appendix 1]

\section{Multimedia Appendix 2}

Study overlap.

[DOCX File, 93 KB-Multimedia Appendix 2]

\section{Multimedia Appendix 3}

Included studies in reviews.

[DOCX File, 30 KB-Multimedia Appendix 3]

\section{Multimedia Appendix 4}

Detailed quality assessment.

[DOCX File, 27 KB-Multimedia Appendix 4]

\section{Multimedia Appendix 5}

Guideline recommendations.

[DOCX File, 22 KB-Multimedia Appendix 5]

\section{References}

1. Rains LS, Johnson S, Barnett P, Steare T, Needle J, Carr S, COVID-19 Mental Health Policy Research Unit Group. Early impacts of the COVID-19 pandemic on mental health care and on people with mental health conditions: framework synthesis of international experiences and responses. Soc Psychiatry Psychiatr Epidemiol 2021 Jan;56(1):13-24 [FREE Full text] [doi: 10.1007/s00127-020-01924-7] [Medline: 32804258]

2. Johnson S, Dalton-Locke C, Juan NV, Foye U, Oram S, Papamichail A, COVID-19 Mental Health Policy Research Unit Group. Impact on mental health care and on mental health service users of the COVID-19 pandemic: a mixed methods survey of UK mental health care staff. Soc Psychiatry Psychiatr Epidemiol 2021 Jan;56(1):25-37 [FREE Full text] [doi: 10.1007/s00127-020-01927-4] [Medline: 32857218]

3. Daigle P, Rudnick A. Shifting to remotely delivered mental health care: quality improvement in the COVID-19 pandemic. Psychiatry Int 2020 Sep 22;1(1):31-35. [doi: 10.3390/psychiatryint1010005]

4. Moreno C, Wykes T, Galderisi S, Nordentoft M, Crossley N, Jones N, et al. How mental health care should change as a consequence of the COVID-19 pandemic. Lancet Psychiatry 2020 Sep;7(9):813-824. [doi: 10.1016/s2215-0366(20)30307-2]

5. Hilty DM, Ferrer DC, Parish MB, Johnston B, Callahan EJ, Yellowlees PM. The effectiveness of telemental health: a 2013 review. Telemed J E Health 2013 Jun;19(6):444-454 [FREE Full text] [doi: 10.1089/tmj.2013.0075] [Medline: 23697504]

6. Yellowlees P, Chan SR, Parish MB. The hybrid doctor-patient relationship in the age of technology - telepsychiatry consultations and the use of virtual space. Int Rev Psychiatry 2015 Oct 23;27(6):476-489. [doi: 10.3109/09540261.2015.1082987] [Medline: 26493089]

7. Hubley S, Lynch SB, Schneck C, Thomas M, Shore J. Review of key telepsychiatry outcomes. World J Psychiatry 2016 Jun 22;6(2):269-282 [FREE Full text] [doi: 10.5498/wjp.v6.i2.269] [Medline: 27354970]

8. Aboujaoude E. Telemental health: why the revolution has not arrived. World Psychiatry 2018 Oct 07;17(3):277-278 [FREE Full text] [doi: 10.1002/wps.20551] [Medline: 30192097]

9. Primm A, Vasquez M, Mays R, Sammons-Posey D, McKnight-Eily L, Presley-Cantrell L, et al. The role of public health in addressing racial and ethnic disparities in mental health and mental illness. Prev Chronic Dis 2010 Jan;7(1):A20 [FREE Full text] [Medline: 20040235]

10. Luxton DD, Pruitt LD, Osenbach JE. Best practices for remote psychological assessment via telehealth technologies. Prof Psychol Res Pract 2014 Feb;45(1):27-35. [doi: 10.1037/a0034547]

11. Stoll J, Müller JA, Trachsel M. Ethical issues in online psychotherapy: a narrative review. Front Psychiatry 2019 Feb 11;10:993 [FREE Full text] [doi: 10.3389/fpsyt.2019.00993] [Medline: 32116819] 
12. Tullio V, Perrone G, Bilotta C, Lanzarone A, Argo A. Psychological support and psychotherapy via digital devices in Covid-19 emergency time: some critical issues. Med Leg J 2020 Jul 03;88(2):73-76. [doi: 10.1177/0025817220926942] [Medline: $\underline{\text { 32490713] }}$

13. Pieper D, Antoine S, Mathes T, Neugebauer EA, Eikermann M. Systematic review finds overlapping reviews were not mentioned in every other overview. J Clin Epidemiol 2014 Apr;67(4):368-375. [doi: 10.1016/j.jclinepi.2013.11.007] [Medline: 24581293]

14. World Health Organization, Alliance for Health Policy and Systems Research. In: Tricco A, Langlois E, Straus S, editors. Rapid Reviews to Strengthen Health Policy and Systems: A Practical Guide. Geneva: World Health Organization; 2017:1-119.

15. Moher D, Liberati A, Tetzlaff J, Altman DG, PRISMA Group. Preferred reporting items for systematic reviews and meta-analyses: the PRISMA statement. PLoS Med 2009 Jul 21;6(7):e1000097 [FREE Full text] [doi: 10.1371/journal.pmed.1000097] [Medline: 19621072]

16. Fusar-Poli P, Radua J. Ten simple rules for conducting umbrella reviews. Evid Based Ment Health 2018 Aug 13;21(3):95-100. [doi: 10.1136/ebmental-2018-300014] [Medline: 30006442]

17. Shea BJ, Reeves BC, Wells G, Thuku M, Hamel C, Moran J, et al. AMSTAR 2: a critical appraisal tool for systematic reviews that include randomised or non-randomised studies of healthcare interventions, or both. Br Med J 2017 Sep 21;358:j4008 [FREE Full text] [doi: 10.1136/bmj.j4008] [Medline: 28935701]

18. Shea BJ, Grimshaw JM, Wells GA, Boers M, Andersson N, Hamel C, et al. Development of AMSTAR: a measurement tool to assess the methodological quality of systematic reviews. BMC Med Res Methodol 2007 Feb 15;7(1):10 [FREE Full text] [doi: 10.1186/1471-2288-7-10] [Medline: 17302989]

19. Shea BJ, Bouter LM, Peterson J, Boers M, Andersson N, Ortiz Z, et al. External validation of a measurement tool to assess systematic reviews (AMSTAR). PLoS One 2007 Dec 26;2(12):e1350 [FREE Full text] [doi: 10.1371/journal.pone.0001350] [Medline: 18159233]

20. Harerimana B, Forchuk C, O'Regan T. The use of technology for mental healthcare delivery among older adults with depressive symptoms: a systematic literature review. Int J Ment Health Nurs 2019 Jun 21;28(3):657-670. [doi: 10.1111/inm.12571] [Medline: 30666762]

21. Dorstyn DS, Saniotis A, Sobhanian F. A systematic review of telecounselling and its effectiveness in managing depression amongst minority ethnic communities. J Telemed Telecare 2013 Oct 17;19(6):338-346. [doi: 10.1177/1357633x13501767]

22. Berryhill MB, Culmer N, Williams N, Halli-Tierney A, Betancourt A, Roberts H, et al. Videoconferencing psychotherapy and depression: a systematic review. Telemed J E Health 2019 Jun;25(6):435-446. [doi: 10.1089/tmj.2018.0058] [Medline: 30048211]

23. Berryhill MB, Halli-Tierney A, Culmer N, Williams N, Betancourt A, King M, et al. Videoconferencing psychological therapy and anxiety: a systematic review. Fam Pract 2019 Jan 25;36(1):53-63. [doi: 10.1093/fampra/cmy072] [Medline: 30188992]

24. Bolton A, Dorstyn D. Telepsychology for posttraumatic stress disorder: a systematic review. J Telemed Telecare 2015 Feb 22;21(5):254-267. [doi: 10.1177/1357633x15571996]

25. Christensen LF, Moller AM, Hansen JP, Nielsen CT, Gildberg FA. Patients' and providers' experiences with video consultations used in the treatment of older patients with unipolar depression: a systematic review. J Psychiatr Ment Health Nurs 2020 Jun 26;27(3):258-271. [doi: 10.1111/jpm.12574] [Medline: 31677331]

26. Coughtrey AE, Pistrang N. The effectiveness of telephone-delivered psychological therapies for depression and anxiety: a systematic review. J Telemed Telecare 2016 Dec 30;24(2):65-74. [doi: 10.1177/1357633x16686547]

27. Drago A, Winding T, Antypa N. Videoconferencing in psychiatry, a meta-analysis of assessment and treatment. Eur Psychiatry 2016 Aug 23;36:29-37. [doi: 10.1016/j.eurpsy.2016.03.007] [Medline: 27311105]

28. García-Lizana F, Muñoz-Mayorga I. What about telepsychiatry? Prim Care Companion J Clin Psychiatry 2010 Mar 25:A. [doi: 10.4088/pcc.09m00831whi]

29. Hassan A, Sharif K. Efficacy of telepsychiatry in refugee populations: a systematic review of the evidence. Cureus 2019 Jan 30;11(1):e3984 [FREE Full text] [doi: 10.7759/cureus.3984] [Medline: 30972263]

30. Lin L, Casteel D, Shigekawa E, Weyrich MS, Roby DH, McMenamin SB. Telemedicine-delivered treatment interventions for substance use disorders: a systematic review. J Subst Abuse Treat 2019 Jun;101:38-49. [doi: 10.1016/j.jsat.2019.03.007] [Medline: 31006553]

31. Lins S, Rücker G, Motschall E, Langer G, Antes G, Meyer G. Efficacy and experiences of telephone counselling for informal carers of people with dementia. Cochrane Database Syst Rev 2011:CD009126. [doi: 10.1002/14651858.CD009126]

32. Muskens EM, Lucassen P, Groenleer W, van Weel C, Oude Voshaar R, Speckens A. Psychiatric diagnosis by telephone: is it an opportunity? Soc Psychiatry Psychiatr Epidemiol 2014 Oct 15;49(10):1677-1689. [doi: 10.1007/s00127-014-0861-9] [Medline: 24632782]

33. Naslund JA, Mitchell LM, Joshi U, Nagda D, Lu C. Economic evaluation and costs of telepsychiatry programmes: a systematic review. J Telemed Telecare 2020 Aug 03:1357633X2093891. [doi: 10.1177/1357633x20938919]

34. Norwood C, Moghaddam NG, Malins S, Sabin-Farrell R. Working alliance and outcome effectiveness in videoconferencing psychotherapy: a systematic review and noninferiority meta-analysis. Clin Psychol Psychother 2018 Nov 16;25(6):797-808. [doi: 10.1002/cpp.2315] [Medline: $\underline{\text { 30014606] }}$ 
35. Olthuis J, Watt M, Bailey K, Hayden J, Stewart S. Therapist-supported internet cognitive behavioural therapy for anxiety disorders in adults. Cochrane Database Syst Rev 2016 Mar 12;3:CD011565 [FREE Full text] [doi: 10.1002/14651858.CD011565.pub2] [Medline: 26968204]

36. Olthuis JV, Wozney L, Asmundson GJ, Cramm H, Lingley-Pottie P, McGrath PJ. Distance-delivered interventions for PTSD: a systematic review and meta-analysis. J Anxiety Disord 2016 Dec;44:9-26. [doi: 10.1016/j.janxdis.2016.09.010] [Medline: 27697658]

37. Sansom-Daly UM, Wakefield CE, McGill BC, Wilson HL, Patterson P. Consensus among international ethical guidelines for the provision of videoconferencing-based mental health treatments. JMIR Ment Health 2016 May 18;3(2):e17 [FREE Full text] [doi: 10.2196/mental.5481] [Medline: 27192931]

38. Turgoose D, Ashwick R, Murphy D. Systematic review of lessons learned from delivering tele-therapy to veterans with post-traumatic stress disorder. J Telemed Telecare 2017 Sep 29;24(9):575-585. [doi: 10.1177/1357633x17730443]

39. Popay J, Roberts H, Sowden A, Petticrew M, Arai L, Rodgers M, et al. Guidance on the conduct of narrative synthesis in systematic reviews. A Product From the ESRC Methods Programme Version. 2006. URL: https://www.lancaster.ac.uk/ media/lancaster-university/content-assets/documents/fhm/dhr/chir/NSsynthesisguidanceVersion1-April2006.pdf [accessed 2021-06-26]

40. Aburizik A, Dindo L, Kaboli P, Charlton M, Dawn K, Turvey C. A pilot randomized controlled trial of a depression and disease management program delivered by phone. J Affect Disord 2013 Nov;151(2):769-774. [doi: 10.1016/j.jad.2013.06.028] [Medline: 23871127]

41. Acierno R, Gros DF, Ruggiero KJ, Hernandez-Tejada BM, Knapp RG, Lejuez CW, et al. Behavioral activation and therapeutic exposure for posttraumatic stress disorder: a noninferiority trial of treatment delivered in person versus home-based telehealth. Depress Anxiety 2016 May;33(5):415-423. [doi: 10.1002/da.22476] [Medline: 26864655]

42. Acierno R, Knapp R, Tuerk P, Gilmore AK, Lejuez C, Ruggiero K, et al. A non-inferiority trial of Prolonged Exposure for posttraumatic stress disorder: in person versus home-based telehealth. Behav Res Ther 2017 Feb;89:57-65 [FREE Full text] [doi: 10.1016/j.brat.2016.11.009] [Medline: 27894058]

43. Ahmed SN, Mann C, Sinclair DB, Heino A, Iskiw B, Quigley D, et al. Feasibility of epilepsy follow-up care through telemedicine: a pilot study on the patient's perspective. Epilepsia 2008 Apr;49(4):573-585 [FREE Full text] [doi: 10.1111/j.1528-1167.2007.01464.x] [Medline: 18076644]

44. Amarendran V, George A, Gersappe V, Krishnaswamy S, Warren C. The reliability of telepsychiatry for a neuropsychiatric assessment. Telemed J E Health 2011 Apr;17(3):223-225. [doi: 10.1089/tmj.2010.0144] [Medline: 21443440]

45. Andersson G, Bergström J, Holländare F, Carlbring P, Kaldo V, Ekselius L. Internet-based self-help for depression: randomised controlled trial. Br J Psychiatry 2005 Nov;187:456-461. [doi: 10.1192/bjp.187.5.456] [Medline: 16260822]

46. Andersson G, Waara J, Jonsson U, Malmaeus F, Carlbring P, Ost LG. Internet-based self-help versus one-session exposure in the treatment of spider phobia: a randomized controlled trial. Cogn Behav Ther 2009;38(2):114-120. [doi: 10.1080/16506070902931326] [Medline: 20183690]

47. Andersson G, Paxling B, Roch-Norlund P, Östman G, Norgren A, Almlöv J, et al. Internet-based psychodynamic versus cognitive behavioral guided self-help for generalized anxiety disorder: a randomized controlled trial. Psychother Psychosom 2012;81(6):344-355 [FREE Full text] [doi: 10.1159/000339371] [Medline: 22964540]

48. Andersson G, Carlbring P, Furmark T, S. O. F. I. E. Research Group. Therapist experience and knowledge acquisition in internet-delivered CBT for social anxiety disorder: a randomized controlled trial. PLoS One 2012;7(5):e37411 [FREE Full text] [doi: 10.1371/journal.pone.0037411] [Medline: 22649526]

49. Andersson G, Waara J, Jonsson U, Malmaeus F, Carlbring P, Ost LG. Internet-based exposure treatment versus one-session exposure treatment of snake phobia: a randomized controlled trial. Cogn Behav Ther 2013;42(4):284-291. [doi: 10.1080/16506073.2013.844202] [Medline: 24245707]

50. Arnaert A, Klooster J, Chow V. Attitudes toward videotelephones: an exploratory study of older adults with depression. J Gerontol Nurs 2007 Sep;33(9):5-13. [doi: 10.3928/00989134-20070901-02] [Medline: 17899995]

51. Aziz MA, Kenford S. Comparability of telephone and face-to-face interviews in assessing patients with posttraumatic stress disorder. J Psychiatr Pract 2004 Sep;10(5):307-313. [doi: 10.1097/00131746-200409000-00004] [Medline: 15361745]

52. Baca CT, Manuel JK. Satisfaction with long-distance motivational interviewing for problem drinking. Addict Disord Their Treat 2007;6(1):39-41 [FREE Full text] [doi: 10.1097/01.adt.0000210708.57327.28]

53. Barrera-Valencia C, Benito-Devia AV, Vélez-Álvarez C, Figueroa-Barrera M, Franco-Idárraga SM. [Cost-effectiveness of synchronous vs. asynchronous telepsychiatry in prison inmates with depression]. Rev Colomb Psiquiatr 2017;46(2):65-73. [doi: 10.1016/j.rcp.2016.04.008] [Medline: 28483175]

54. Berger T, Hohl E, Caspar F. Internet-based treatment for social phobia: a randomized controlled trial. J Clin Psychol 2009 Oct;65(10):1021-1035. [doi: 10.1002/jclp.20603] [Medline: 19437505]

55. Berger T, Caspar F, Richardson R, Kneubühler B, Sutter D, Andersson G. Internet-based treatment of social phobia: a randomized controlled trial comparing unguided with two types of guided self-help. Behav Res Ther 2011 Mar;49(3):158-169. [doi: 10.1016/j.brat.2010.12.007] [Medline: 21255767] 
56. Berger T, Boettcher J, Caspar F. Internet-based guided self-help for several anxiety disorders: a randomized controlled trial comparing a tailored with a standardized disorder-specific approach. Psychotherapy (Chic) 2014 Jun;51(2):207-219. [doi: 10.1037/a0032527] [Medline: 24041199]

57. Bergström J, Andersson G, Ljótsson B, Rück C, Andréewitch S, Karlsson A, et al. Internet-versus group-administered cognitive behaviour therapy for panic disorder in a psychiatric setting: a randomised trial. BMC Psychiatry 2010 Jul 02;10:54 [FREE Full text] [doi: 10.1186/1471-244X-10-54] [Medline: 20598127]

58. Bishop JE, O'Reilly RL, Maddox K, Hutchinson LJ. Client satisfaction in a feasibility study comparing face-to-face interviews with telepsychiatry. J Telemed Telecare 2002;8(4):217-221. [doi: 10.1258/135763302320272185] [Medline: 12217104]

59. Bouchard S, Paquin B, Payeur R, Allard M, Rivard V, Fournier T, et al. Delivering cognitive-behavior therapy for panic disorder with agoraphobia in videoconference. Telemed J E Health 2004;10(1):13-25. [doi: 10.1089/153056204773644535] [Medline: 15104911]

60. Brøndbo H, Mathiassen B, Martinussen M, Heiervang E, Eriksen M, Kvernmo S. Agreement on web-based diagnoses and severity of mental health problems in norwegian child and adolescent mental health services. Clin Pract Epidemiol Ment Health 2012;8:16-21 [FREE Full text] [doi: 10.2174/1745017901208010016] [Medline: 22582083]

61. Brooks E, Novins DK, Noe T, Bair B, Dailey N, Lowe J, et al. Reaching rural communities with culturally appropriate care: a model for adapting remote monitoring to American Indian veterans with posttraumatic stress disorder. Telemed J E Health 2013 Apr;19(4):272-277. [doi: 10.1089/tmj.2012.0117] [Medline: 23451811]

62. Burke WJ, Roccaforte WH, Wengel SP, Conley DM, Potter JF. The reliability and validity of the Geriatric Depression Rating Scale administered by telephone. J Am Geriatr Soc 1995 Jun;43(6):674-679. [doi: 10.1111/j.1532-5415.1995.tb07205.x] [Medline: 7775729]

63. Butler TN, Yellowlees P. Cost analysis of store-and-forward telepsychiatry as a consultation model for primary care. Telemed J E Health 2012;18(1):74-77. [doi: 10.1089/tmj.2011.0086] [Medline: 22085113]

64. Cacciola JS, Alterman AI, Rutherford MJ, McKay JR, May DJ. Comparability of telephone and In-person structured clinical interview for DSM-III-R (SCID) diagnoses. Assessment 1999 Sep;6(3):235-242. [doi: 10.1177/107319119900600304] [Medline: 10445961]

65. Carlbring P, Nilsson-Ihrfelt E, Waara J, Kollenstam C, Buhrman M, Kaldo V, et al. Treatment of panic disorder: live therapy vs. self-help via the internet. Behav Res Ther 2005 Oct;43(10):1321-1333. [doi: 10.1016/j.brat.2004.10.002] [Medline: 16086983]

66. Carlbring P, Bohman S, Brunt S, Buhrman M, Westling BE, Ekselius L, et al. Remote treatment of panic disorder: a randomized trial of internet-based cognitive behavior therapy supplemented with telephone calls. Am J Psychiatry 2006 Dec;163(12):2119-2125. [doi: 10.1176/ajp.2006.163.12.2119] [Medline: 17151163]

67. Carlbring P, Gunnarsdóttir M, Hedensjö L, Andersson G, Ekselius L, Furmark T. Treatment of social phobia: randomised trial of internet-delivered cognitive-behavioural therapy with telephone support. Br J Psychiatry 2007 Feb;190:123-128. [doi: 10.1192/bjp.bp.105.020107] [Medline: 17267928]

68. Carlson LE, Lounsberry JJ, Maciejewski O, Wright K, Collacutt V, Taenzer P. Telehealth-delivered group smoking cessation for rural and urban participants: feasibility and cessation rates. Addict Behav 2012 Jan;37(1):108-114. [doi: 10.1016/j.addbeh.2011.09.011] [Medline: 21968227]

69. Cernvall M, Carlbring P, Ljungman L, Ljungman G, von Essen L. Internet-based guided self-help for parents of children on cancer treatment: a randomized controlled trial. Psychooncology 2015 Sep;24(9):1152-1158 [FREE Full text] [doi: 10.1002/pon.3788] [Medline: 25728688]

70. Chang BL. Cognitive-behavioral intervention for homebound caregivers of persons with dementia. Nurs Res 1999;48(3):173-182. [doi: 10.1097/00006199-199905000-00007] [Medline: 10337848]

71. Chang BL, Nitta S, Carter PA, Markham YK. Perceived helpfulness of telephone calls - providing support for caregivers of family members with dementia. J Gerontol Nurs 2004 Sep;30(9):14-21. [doi: 10.3928/0098-9134-20040901-05] [Medline: 15471059]

72. Weintraub E, Greenblatt AD, Chang J, Himelhoch S, Welsh C. Expanding access to buprenorphine treatment in rural areas with the use of telemedicine. Am J Addict 2018 Dec;27(8):612-617. [doi: 10.1111/ajad.12805] [Medline: 30265425]

73. Chiu T, Marziali E, Colantonio A, Carswell A, Gruneir M, Tang M, et al. Internet-based caregiver support for Chinese Canadians taking care of a family member with alzheimer disease and related dementia. Can J Aging 2009 Dec;28(4):323-336. [doi: 10.1017/S0714980809990158] [Medline: 19925698]

74. Choi I, Zou J, Titov N, Dear BF, Li SD, Johnston L, et al. Culturally attuned Internet treatment for depression amongst Chinese Australians: a randomised controlled trial. J Affect Disord 2012 Feb;136(3):459-468. [doi: 10.1016/j.jad.2011.11.003] [Medline: 22177742]

75. Choi NG, Wilson NL, Sirrianni L, Marinucci ML, Hegel MT. Acceptance of home-based telehealth problem-solving therapy for depressed, low-income homebound older adults: qualitative interviews with the participants and aging-service case managers. Gerontologist 2014 Aug;54(4):704-713 [FREE Full text] [doi: 10.1093/geront/gnt083] [Medline: 23929664] 
76. Choi NG, Marti CN, Bruce ML, Hegel MT, Wilson NL, Kunik ME. Six-month postintervention depression and disability outcomes of in-home telehealth problem-solving therapy for depressed, low-income homebound older adults. Depress Anxiety 2014 Aug;31(8):653-661 [FREE Full text] [doi: 10.1002/da.22242] [Medline: 24501015]

77. Choi NG, Hegel MT, Marti N, Marinucci ML, Sirrianni L, Bruce ML. Telehealth problem-solving therapy for depressed low-income homebound older adults. Am J Geriatr Psychiatry 2014 Mar;22(3):263-271 [FREE Full text] [doi: 10.1097/JGP.0b013e318266b356] [Medline: 23567376]

78. Chong J, Moreno F. Feasibility and acceptability of clinic-based telepsychiatry for low-income Hispanic primary care patients. Telemed J E Health 2012 May;18(4):297-304. [doi: 10.1089/tmj.2011.0126] [Medline: 22424078]

79. Clapp JD, Kemp JJ, Cox KS, Tuerk PW. Patterns of change in response to prolonged exposure: implications for treatment outcome. Depress Anxiety 2016 Sep;33(9):807-815. [doi: 10.1002/da.22534] [Medline: 27321062]

80. Conn DK, Madan R, Lam J, Patterson T, Skirten S. Program evaluation of a telepsychiatry service for older adults connecting a university-affiliated geriatric center to a rural psychogeriatric outreach service in Northwest Ontario, Canada. Int Psychogeriatr 2013 Nov;25(11):1795-1800. [doi: 10.1017/S104161021300118X] [Medline: 23870297]

81. Cowain T. Cognitive-behavioural therapy via videoconferencing to a rural area. Aust N Z J Psychiatry 2001 Feb;35(1):62-64. [doi: 10.1046/j.1440-1614.2001.00853.x] [Medline: 11270458]

82. Crippa JA, de Lima Osório F, Del-Ben CM, Filho AS, da Silva Freitas MC, Loureiro SR. Comparability between telephone and face-to-face structured clinical interview for DSM-IV in assessing social anxiety disorder. Perspect Psychiatr Care 2008 Oct;44(4):241-247. [doi: 10.1111/j.1744-6163.2008.00183.x] [Medline: 18826462 ]

83. Crowe T, Jani S, Jani S, Jani N, Jani R. A pilot program in rural telepsychiatry for deaf and hard of hearing populations. Heliyon 2016 Mar;2(3):e00077 [FREE Full text] [doi: 10.1016/j.heliyon.2016.e00077] [Medline: 27441259]

84. Davis LL, Burgio LD, Buckwalter KC, Weaver M. A comparison of in-home and telephone-based skill training interventions with caregivers of persons with Dementia. J Ment Health Aging 2004;10(1):31-44 [FREE Full text]

85. De Las Cuevas C, Artiles J, De La Fuente J, Serrano P. Telepsychiatry in the Canary Islands: user acceptance and satisfaction. J Telemed Telecare 2003;9(4):221-224. [doi: 10.1258/135763303322225553] [Medline: 12952693]

86. De Las Cuevas C, Arredondo MT, Cabrera MF, Sulzenbacher HJ, Meise U. Randomized clinical trial of telepsychiatry through videoconference versus face-to-face conventional psychiatric treatment. Telemed J E Health 2006 Jun;12(3):341-350. [doi: $10.1089 /$ tmj.2006.12.341] [Medline: 16796502$]$

87. Leo J, Lamb K, LaRowe S, Ana E. A brief behavioral telehealth intervention for veterans with alcohol misuse problems in VA primary care. Drug Alcohol Depend 2014 Jul;140:e45. [doi: 10.1016/j.drugalcdep.2014.02.144]

88. Demiris G, Oliver DP, Wittenberg-Lyles E, Washington K. Use of videophones to deliver a cognitive-behavioural therapy to hospice caregivers. J Telemed Telecare 2011;17(3):142-145 [FREE Full text] [doi: 10.1258/jtt.2010.100503] [Medline: 21303934]

89. Dobkin RD, Menza M, Allen LA, Tiu J, Friedman J, Bienfait KL, et al. Telephone-based cognitive-behavioral therapy for depression in Parkinson disease. J Geriatr Psychiatry Neurol 2011 Dec;24(4):206-214 [FREE Full text] [doi: 10.1177/0891988711422529] [Medline: 22228827]

90. DuHamel KN, Mosher CE, Winkel G, Labay LE, Rini C, Meschian YM, et al. Randomized clinical trial of telephone-administered cognitive-behavioral therapy to reduce post-traumatic stress disorder and distress symptoms after hematopoietic stem-cell transplantation. J Clin Oncol 2010 Aug 10;28(23):3754-3761 [FREE Full text] [doi: 10.1200/JCO.2009.26.8722] [Medline: 20625129]

91. Dunstan DA, Tooth SM. Treatment via videoconferencing: a pilot study of delivery by clinical psychology trainees. Aust J Rural Health 2012 Apr;20(2):88-94. [doi: 10.1111/j.1440-1584.2012.01260.x] [Medline: 22435769]

92. Dwight-Johnson M, Aisenberg E, Golinelli D, Hong S, O'Brien M, Ludman E. Telephone-based cognitive-behavioral therapy for Latino patients living in rural areas: a randomized pilot study. Psychiatr Serv 2011 Aug;62(8):936-942 [FREE Full text] [doi: $10.1176 /$ ps.62.8.pss6208 0936] [Medline: 21807834]

93. Egede LE, Acierno R, Knapp RG, Walker RJ, Payne EH, Frueh BC. Psychotherapy for depression in older veterans via telemedicine: effect on quality of life, satisfaction, treatment credibility, and service delivery perception. J Clin Psychiatry 2016 Dec;77(12):1704-1711. [doi: 10.4088/JCP.16m10951] [Medline: 27835713]

94. Egede LE, Gebregziabher M, Walker RJ, Payne EH, Acierno R, Frueh BC. Trajectory of cost overtime after psychotherapy for depression in older Veterans via telemedicine. J Affect Disord 2017 Jan 01;207:157-162. [doi: 10.1016/j.jad.2016.09.044] [Medline: 27721190]

95. Eibl JK, Gauthier G, Pellegrini D, Daiter J, Varenbut M, Hogenbirk JC, et al. The effectiveness of telemedicine-delivered opioid agonist therapy in a supervised clinical setting. Drug Alcohol Depend 2017 Jul 01;176:133-138 [FREE Full text] [doi: 10.1016/j.drugalcdep.2017.01.048] [Medline: 28535455]

96. Eisdorfer C, Czaja SJ, Loewenstein DA, Rubert MP, Argüelles S, Mitrani VB, et al. The effect of a family therapy and technology-based intervention on caregiver depression. Gerontologist 2003 Aug;43(4):521-531 [FREE Full text] [doi: 10.1093/geront/43.4.521] [Medline: 12937331$]$

97. Elford R, White H, Bowering R, Ghandi A, Maddiggan B, St John K, et al. A randomized, controlled trial of child psychiatric assessments conducted using videoconferencing. J Telemed Telecare 2000;6(2):73-82. [doi: 10.1258/1357633001935086] [Medline: 10824374] 
98. Elford DR, White H, St John K, Maddigan B, Ghandi M, Bowering R. A prospective satisfaction study and cost analysis of a pilot child telepsychiatry service in Newfoundland. J Telemed Telecare 2001;7(2):73-81. [doi: 10.1258/1357633011936192] [Medline: 11331044]

99. Engel CC, Litz B, Magruder KM, Harper E, Gore K, Stein N, et al. Delivery of self training and education for stressful situations (DESTRESS-PC): a randomized trial of nurse assisted online self-management for PTSD in primary care. Gen Hosp Psychiatry 2015;37(4):323-328 [FRE Full text] [doi: 10.1016/j.genhosppsych.2015.04.007] [Medline: 25929985]

100. Evans M, Kessler D, Lewis G, Peters TJ, Sharp D. Assessing mental health in primary care research using standardized scales: can it be carried out over the telephone? Psychol Med 2004 Jan;34(1):157-162. [doi: 10.1017/s0033291703008055] [Medline: 14971636$]$

101. Finkel S, Czaja SJ, Schulz R, Martinovich Z, Harris C, Pezzuto D. E-care: a telecommunications technology intervention for family caregivers of dementia patients. Am J Geriatr Psychiatry 2007 May;15(5):443-448. [doi: 10.1097/JGP.0b013e3180437d87] [Medline: 17463195]

102. Fitt S, Rees C. Metacognitive therapy for obsessive compulsive disorder by videoconference: a preliminary study. Behav Change 2013 Jan 09;29(4):213-229. [doi: 10.1017/bec.2012.21]

103. Fortney JC, Pyne JM, Edlund MJ, Williams DK, Robinson DE, Mittal D, et al. A randomized trial of telemedicine-based collaborative care for depression. J Gen Intern Med 2007 Aug;22(8):1086-1093 [FREE Full text] [doi:

10.1007/s11606-007-0201-9] [Medline: 17492326]

104. Fortney JC, Pyne JM, Mouden SB, Mittal D, Hudson TJ, Schroeder GW, et al. Practice-based versus telemedicine-based collaborative care for depression in rural federally qualified health centers: a pragmatic randomized comparative effectiveness trial. Am J Psychiatry 2013 Apr;170(4):414-425 [FREE Full text] [doi: 10.1176/appi.ajp.2012.12050696] [Medline: 23429924]

105. Fortney JC, Pyne JM, Kimbrell TA, Hudson TJ, Robinson DE, Schneider R, et al. Telemedicine-based collaborative care for posttraumatic stress disorder: a randomized clinical trial. JAMA Psychiatry 2015 Jan;72(1):58-67. [doi:

10.1001/jamapsychiatry.2014.1575] [Medline: 25409287]

106. Frank F, Ower N, Zech J, Röhrig J, Gräder N, Berger M, et al. Video conference-based psychotherapeutic follow-up treatment - qualitative case study using a CBASP approach. Psychotherapeut 2017 Mar 30;62(4):355-360. [doi: 10.1007/s00278-017-0181-0] [Medline: $\underline{10}$ ]

107. Franklin CL, Cuccurullo LA, Walton JL, Arseneau JR, Petersen NJ. Face to face but not in the same place: a pilot study of prolonged exposure therapy. J Trauma Dissociation 2017;18(1):116-130. [doi: 10.1080/15299732.2016.1205704] [Medline: 27348462]

108. Frueh BC, Monnier J, Yim EN, Grubaugh AL, Hamner MB, Knapp RG. A randomized trial of telepsychiatry for post-traumatic stress disorder. J Telemed Telecare 2007;13(3):142-147. [doi: 10.1258/135763307780677604] [Medline: $\underline{17519056}$

109. Frueh BC, Henderson S, Myrick H. Telehealth service delivery for persons with alcoholism. J Telemed Telecare 2005;11(7):372-375. [doi: 10.1258/135763305774472060] [Medline: 16238840]

110. Frueh BC, Monnier J, Grubaugh AL, Elhai JD, Yim E, Knapp R. Therapist adherence and competence with manualized cognitive-behavioral therapy for PTSD delivered via videoconferencing technology. Behav Modif 2007 Nov;31(6):856-866. [doi: 10.1177/0145445507302125] [Medline: 17932240]

111. Furmark T, Carlbring P, Hedman E, Sonnenstein A, Clevberger P, Bohman B, et al. Guided and unguided self-help for social anxiety disorder: randomised controlled trial. Br J Psychiatry 2009 Nov;195(5):440-447. [doi: 10.1192/bjp.bp.108.060996] [Medline: 19880935]

112. Gant JR, Steffen AM, Lauderdale SA. Comparative outcomes of two distance-based interventions for male caregivers of family members with dementia. Am J Alzheimers Dis Other Demen 2007;22(2):120-128 [FREE Full text] [doi: 10.1177/1533317506298880] [Medline: 17545139]

113. Garzón-Maldonado FJ, Gutiérrez-Bedmar M, Serrano-Castro V, Requena-Toro MV, Padilla-Romero L, García-Casares $\mathrm{N}$. An assessesment of telephone assistance systems for caregivers of patients with Alzheimer's disease. Neurologia 2017;32(9):595-601 [FREE Full text] [doi: 10.1016/j.nrl.2016.03.009] [Medline: 27293022]

114. Gerlach-Reinholz W, Drop L, Basic E, Rauchhaus M, Fritze J. [Telephone coaching for depression]. Nervenarzt 2017 Jul;88(7):811-818. [doi: 10.1007/s00115-017-0316-0] [Medline: 28429078]

115. Germain V, Marchand A, Bouchard S, Drouin MS, Guay S. Effectiveness of cognitive behavioural therapy administered by videoconference for posttraumatic stress disorder. Cogn Behav Ther 2009;38(1):42-53. [doi: 10.1080/16506070802473494] [Medline: 19235601$]$

116. Glueckauf RL, Davis WS, Willis F, Sharma D, Gustafson DJ, Hayes J, et al. Telephone-based, cognitive-behavioral therapy for African American dementia caregivers with depression: initial findings. Rehabil Psychol 2012 May;57(2):124-139. [doi: 10.1037/a0028688] [Medline: 22686551]

117. Godleski L, Cervone D, Vogel D, Rooney M. Home telemental health implementation and outcomes using electronic messaging. J Telemed Telecare 2012 Jan;18(1):17-19. [doi: 10.1258/jtt.2011.100919] [Medline: 22052966]

118. Gonzalez GE, Brossart DF. Telehealth videoconferencing psychotherapy in rural primary care. J Rur Ment Health 2015 Jul;39(3-4):137-152. [doi: 10.1037/rmh0000037] 
119. Greene CJ, Morland LA, Macdonald A, Frueh BC, Grubbs KM, Rosen CS. How does tele-mental health affect group therapy process? Secondary analysis of a noninferiority trial. J Consult Clin Psychol 2010 Oct;78(5):746-750. [doi: 10.1037/a0020158] [Medline: 20873910]

120. Greenwood J, Chamberlain C, Parker G. Evaluation of a rural telepsychiatry service. Aust Psychiatry 2004 Sep 01;12(3):268-272. [doi: 10.1080/j.1039-8562.2004.02097.x] [Medline: 15715789 ]

121. Griffiths L, Blignault I, Yellowlees P. Telemedicine as a means of delivering cognitive-behavioural therapy to rural and remote mental health clients. J Telemed Telecare 2006;12(3):136-140. [doi: 10.1258/135763306776738567] [Medline: $\underline{16638234]}$

122. Gros DF, Yoder M, Tuerk PW, Lozano BE, Acierno R. Exposure therapy for PTSD delivered to veterans via telehealth: predictors of treatment completion and outcome and comparison to treatment delivered in person. Behav Ther 2011 Jun;42(2):276-283. [doi: 10.1016/j.beth.2010.07.005] [Medline: 21496512]

123. Gros DF, Price M, Strachan M, Yuen EK, Milanak ME, Acierno R. Behavioral activation and therapeutic exposure: an investigation of relative symptom changes in PTSD and depression during the course of integrated behavioral activation, situational exposure, and imaginal exposure techniques. Behav Modif 2012 Jul;36(4):580-599 [FREE Full text] [doi: 10.1177/0145445512448097] [Medline: 22679240]

124. Gros DF, Lancaster CL, López CM, Acierno R. Treatment satisfaction of home-based telehealth versus in-person delivery of prolonged exposure for combat-related PTSD in veterans. J Telemed Telecare 2018 Jan;24(1):51-55. [doi:

10.1177/1357633X16671096] [Medline: 27672059]

125. Grubbs KM, Fortney JC, Pyne JM, Hudson T, Moore WM, Custer P, et al. Predictors of initiation and engagement of cognitive processing therapy among veterans with PSTD enrolled in collaborative care. J Trauma Stress 2015 Dec;28(6):580-584. [doi: 10.1002/jts.22049] [Medline: 26625355]

126. Grubbs KM, Fortney JC, Kimbrell T, Pyne JM, Hudson T, Robinson D, et al. Usual care for rural veterans with posttraumatic stress disorder. J Rural Health 2017 Jun;33(3):290-296. [doi: 10.1111/jrh.12230] [Medline: 28112433]

127. Hajebi A, Motevalian A, Amin-Esmaeili M, Hefazi MS, Radgoodarzi R, Rahimi-Movaghar A, et al. Telephone versus face-to-face administration of the Structured Clinical Interview for Diagnostic and Statistical Manual of Mental Disorders, Fourth Edition, for diagnosis of psychotic disorders. Compr Psychiatry 2012 Jul;53(5):579-583. [doi: 10.1016/j.comppsych.2011.06.001] [Medline: 21820651]

128. Hassija C, Gray MJ. The effectiveness and feasibility of videoconferencing technology to provide evidence-based treatment to rural domestic violence and sexual assault populations. Telemed J E Health 2011 May;17(4):309-315. [doi: 10.1089/tmj.2010.0147] [Medline: 21457012]

129. Hedman E, Andersson G, Ljótsson B, Andersson E, Rück C, Mörtberg E, et al. Internet-based cognitive behavior therapy vs. cognitive behavioral group therapy for social anxiety disorder: a randomized controlled non-inferiority trial. PLoS One 2011 Mar 25;6(3):e18001 [FREE Full text] [doi: 10.1371/journal.pone.0018001] [Medline: 21483704]

130. Hernandez-Tejada MA, Zoller JS, Ruggiero KJ, Kazley AS, Acierno R. Early treatment withdrawal from evidence-based psychotherapy for PTSD: telemedicine and in-person parameters. Int J Psychiatry Med 2014;48(1):33-55. [doi: 10.2190/PM.48.1.d] [Medline: 25354925]

131. Hilty DM, Marks S, Wegelin J, Callahan EJ, Nesbitt TS. A randomized, controlled trial of disease management modules, including telepsychiatric care, for depression in rural primary care. Psychiatry (Edgmont) 2007 Feb;4(2):58-65 [FREE Full text] [Medline: $\underline{20805900]}$

132. Himelhoch S, Mohr D, Maxfield J, Clayton S, Weber E, Medoff D, et al. Feasibility of telephone-based cognitive behavioral therapy targeting major depression among urban dwelling African-American people with co-occurring HIV. Psychol Health Med 2011 Mar;16(2):156-165 [FREE Full text] [doi: 10.1080/13548506.2010.534641] [Medline: 21328144]

133. Himle JA, Fischer DJ, Muroff JR, Van Etten ML, Lokers LM, Abelson JL, et al. Videoconferencing-based cognitive-behavioral therapy for obsessive-compulsive disorder. Behav Res Ther 2006 Dec;44(12):1821-1829. [doi: 10.1016/j.brat.2005.12.010] [Medline: 16466688 ]

134. Hull TD, Mahan K. A study of asynchronous mobile-enabled SMS text psychotherapy. Telemed J E Health 2017 Mar;23(3):240-247. [doi: 10.1089/tmj.2016.0114] [Medline: 27797646]

135. Ivarsson D, Blom M, Hesser H, Carlbring P, Enderby P, Nordberg R, et al. Guided internet-delivered cognitive behavior therapy for post-traumatic stress disorder: a randomized controlled trial. Internet Int 2014 Mar;1(1):33-40. [doi: 10.1016/j.invent.2014.03.002]

136. Jaconis M, Santa Ana EJ, Killeen TK, Badour CL, Back SE. Concurrent treatment of PTSD and alcohol use disorder via telehealth in a female Iraq veteran. Am J Addict 2017 Mar;26(2):112-114 [FREE Full text] [doi: 10.1111/ajad.12481] [Medline: 28118514]

137. Jang Y, Chiriboga DA, Molinari V, Roh S, Park Y, Kwon S, et al. Telecounseling for the linguistically isolated: a pilot study with older Korean immigrants. Gerontologist 2014 Apr;54(2):290-296 [FREE Full text] [doi: 10.1093/geront/gns196] [Medline: 23355448]

138. Johnston L, Titov N, Andrews G, Spence J, Dear BF. A RCT of a transdiagnostic internet-delivered treatment for three anxiety disorders: examination of support roles and disorder-specific outcomes. PLoS One 2011;6(11):e28079 [FREE Full text] [doi: 10.1371/journal.pone.0028079] [Medline: 22132216] 
139. Jones MD, Etherage JR, Harmon SC, Okiishi JC. Acceptability and cost-effectiveness of military telehealth mental health screening. Psychol Serv 2012 May;9(2):132-143. [doi: 10.1037/a0026709] [Medline: 22662728]

140. Jones DJ, Forehand R, Cuellar J, Parent J, Honeycutt A, Khavjou O, et al. Technology-enhanced program for child disruptive behavior disorders: development and pilot randomized control trial. J Clin Child Adolesc Psychol 2014;43(1):88-101 [FREE Full text] [doi: 10.1080/15374416.2013.822308] [Medline: 23924046]

141. Jong M. Managing suicides via videoconferencing in a remote northern community in Canada. Int J Circumpolar Health 2004 Dec;63(4):422-428. [doi: 10.3402/ijch.v63i4.17759] [Medline: 15709317]

142. Kennedy C, Yellowlees P. A community-based approach to evaluation of health outcomes and costs for telepsychiatry in a rural population: preliminary results. J Telemed Telecare 2000;6 Suppl 1:155-157. [doi: 10.1258/1357633001934492] [Medline: 10794004]

143. Kim SS, Sitthisongkram S, Bernstein K, Fang H, Choi WS, Ziedonis D. A randomized controlled trial of a videoconferencing smoking cessation intervention for Korean American women: preliminary findings. Int J Womens Health 2016;8:453-462 [FREE Full text] [doi: 10.2147/IJWH.S109819] [Medline: 27660494]

144. King VL, Stoller KB, Kidorf MM, Kindbom K, Hursh S, Brady T, et al. Assessing the effectiveness of an Internet-based videoconferencing platform for delivering intensified substance abuse counseling. J Subst Abuse Treat 2009 Apr;36(3):331-338. [doi: 10.1016/j.jsat.2008.06.011] [Medline: 18775625]

145. King VL, Brooner RK, Peirce JM, Kolodner K, Kidorf MS. A randomized trial of web-based videoconferencing for substance abuse counseling. J Subst Abuse Treat 2014 Jan;46(1):36-42 [FREE Full text] [doi: 10.1016/j.jsat.2013.08.009] [Medline: 24035556]

146. Kiropoulos LA, Klein B, Austin DW, Gilson K, Pier C, Mitchell J, et al. Is internet-based CBT for panic disorder and agoraphobia as effective as face-to-face CBT? J Anxiety Disord 2008 Dec;22(8):1273-1284. [doi: 10.1016/j.janxdis.2008.01.008] [Medline: 18289829]

147. Klee A, Stacy M, Rosenheck R, Harkness L, Tsai J. Interest in technology-based therapies hampered by access: a survey of veterans with serious mental illnesses. Psychiatr Rehabil J 2016 Jun;39(2):173-179. [doi: 10.1037/prj0000180] [Medline: 26985680]

148. Klein B, Mitchell J, Abbott J, Shandley K, Austin D, Gilson K, et al. A therapist-assisted cognitive behavior therapy internet intervention for posttraumatic stress disorder: pre-, post- and 3-month follow-up results from an open trial. J Anxiety Disord 2010 Aug;24(6):635-644. [doi: 10.1016/j.janxdis.2010.04.005] [Medline: 20447802]

149. Knaevelsrud C, Brand J, Lange A, Ruwaard J, Wagner B. Web-based psychotherapy for posttraumatic stress disorder in war-traumatized Arab patients: randomized controlled trial. J Med Internet Res 2015 Mar 20;17(3):e71 [FREE Full text] [doi: 10.2196/jmir.3582] [Medline: 25799024]

150. Kobak KA, Williams JB, Jeglic E, Salvucci D, Sharp IR. Face-to-face versus remote administration of the Montgomery-Asberg Depression Rating Scale using videoconference and telephone. Depress Anxiety 2008;25(11):913-919. [doi: 10.1002/da.20392] [Medline: 17941100]

151. Kobak KA, Greist R, Jacobi DM, Levy-Mack H, Greist JH. Computer-assisted cognitive behavior therapy for obsessive-compulsive disorder: a randomized trial on the impact of lay vs. professional coaching. Ann Gen Psychiatry 2015;14:10 [FREE Full text] [doi: 10.1186/s12991-015-0048-0] [Medline: 25722737]

152. Kok RN, van Straten A, Beekman AT, Cuijpers P. Short-term effectiveness of web-based guided self-help for phobic outpatients: randomized controlled trial. J Med Internet Res 2014 Sep 29;16(9):e226 [FREE Full text] [doi: 10.2196/jmir.3429] [Medline: 25266929]

153. Lazzari C, Egan SJ, Rees CS. Behavioral activation treatment for depression in older adults delivered via videoconferencing: a pilot study. Cognit Behav Pract 2011 Nov;18(4):555-565. [doi: 10.1016/j.cbpra.2010.11.009]

154. Lewis C, Roberts N, Vick T, Bisson JI. Development of a guided self-help (GSH) program for the treatment of mild-to-moderate posttraumatic stress disorder (PTSD). Depress Anxiety 2013 Nov;30(11):1121-1128. [doi: 10.1002/da.22128] [Medline: 23670782]

155. Lichstein KL, Scogin F, Thomas SJ, DiNapoli EA, Dillon HR, McFadden A. Telehealth cognitive behavior therapy for co-occurring insomnia and depression symptoms in older adults. J Clin Psychol 2013 Oct;69(10):1056-1065 [FREE Full text] [doi: 10.1002/jclp.22030] [Medline: 24014056]

156. Lightstone AJ, Bailey SK, Voros P. Collaborative music therapy via remote video technology to reduce a veteran's symptoms of severe, chronic PTSD. Arts Health 2015 Apr 19;7(2):123-136. [doi: 10.1080/17533015.2015.1019895]

157. Lindsay JA, Kauth MR, Hudson S, Martin LA, Ramsey DJ, Daily L, et al. Implementation of video telehealth to improve access to evidence-based psychotherapy for posttraumatic stress disorder. Telemed J E Health 2015 Jun;21(6):467-472 [FREE Full text] [doi: 10.1089/tmj.2014.0114] [Medline: 25714664]

158. Littleton H, Buck K, Rosman L, Grills-Taquechel A. From survivor to thriver: a pilot study of an online program for rape victims. Cogn Behav Pract 2012 May 01;19(2):315-327 [FREE Full text] [doi: 10.1016/j.cbpra.2011.04.002] [Medline: 24009410]

159. Litz BT, Engel CC, Bryant RA, Papa A. A randomized, controlled proof-of-concept trial of an Internet-based, therapist-assisted self-management treatment for posttraumatic stress disorder. Am J Psychiatry 2007 Nov;164(11):1676-1683. [doi: 10.1176/appi.ajp.2007.06122057] [Medline: 17974932] 
160. Lovell K, Fullalove L, Garvey R, Brooker C. Telephone treatment of obsessive-compulsive disorder. Behav Cogn Psychother 2000 Jan 01;28(1):87-91. [doi: 10.1017/S1352465800000084]

161. Luxton DD, Pruitt LD, O'Brien K, Kramer G. An evaluation of the feasibility and safety of a home-based telemental health treatment for posttraumatic stress in the U.S. military. Telemed J E Health 2015 Nov;21(11):880-886. [doi: 10.1089/tmj.2014.0235] [Medline: 26103565]

162. Luxton DD, Pruitt LD, Wagner A, Smolenski DJ, Jenkins-Guarnieri MA, Gahm G. Home-based telebehavioral health for U.S. military personnel and veterans with depression: a randomized controlled trial. J Consult Clin Psychol 2016 Nov;84(11):923-934. [doi: 10.1037/ccp0000135] [Medline: 27599225]

163. Lyneham HJ, Rapee RM. Agreement between telephone and in-person delivery of a structured interview for anxiety disorders in children. J Am Acad Child Adolesc Psychiatry 2005 Mar;44(3):274-282. [doi: 10.1097/00004583-200503000-00012] [Medline: 15725972$]$

164. Maieritsch KP, Smith TL, Hessinger JD, Ahearn EP, Eickhoff JC, Zhao Q. Randomized controlled equivalence trial comparing videoconference and in person delivery of cognitive processing therapy for PTSD. J Telemed Telecare 2016 Jun;22(4):238-243. [doi: 10.1177/1357633X15596109] [Medline: 26231819]

165. Malhotra S, Chakrabarti S, Shah R, Gupta A, Mehta A, Nithya B, et al. Development of a novel diagnostic system for a telepsychiatric application: a pilot validation study. BMC Res Notes 2014 Aug 09;7:508 [FREE Full text] [doi: 10.1186/1756-0500-7-508] [Medline: 25106438]

166. Manchanda M, McLaren P. Cognitive behaviour therapy via interactive video. J Telemed Telecare 1998;4 Suppl 1:53-55. [doi: 10.1258/1357633981931452] [Medline: 9640736 ]

167. Manguno-Mire GM, Thompson JW, Shore JH, Croy CD, Artecona JF, Pickering JW. The use of telemedicine to evaluate competency to stand trial: a preliminary randomized controlled study. J Am Acad Psychiatry Law 2007;35(4):481-489. [Medline: 18086740$]$

168. Marchand A, Beaulieu-Prévost D, Guay S, Bouchard SK, Drouin M, Germain V. Relative efficacy of cognitive-behavioral therapy administered by videoconference for posttraumatic stress disorder: a six-month follow-up. J Aggress Maltreat Trauma 2011 Apr 14;20(3):304-321 [FREE Full text] [doi: 10.1080/10926771.2011.562479] [Medline: 23687441]

169. Matsuura S, Hosaka T, Yukiyama T, Ogushi Y, Okada Y, Haruki Y, et al. Application of telepsychiatry: a preliminary study. Psychiatry Clin Neurosci 2000 Feb;54(1):55-58 [FREE Full text] [doi: 10.1046/j.1440-1819.2000.00637.x] [Medline: 15558880]

170. McLellan LF, Andrijic V, Davies S, Lyneham HJ, Rapee RM. Delivery of a therapist-facilitated telecare anxiety program to children in rural communities: a pilot study. Behav Change 2017 Aug 22;34(3):156-167. [doi: 10.1017/bec.2017.11]

171. Menon AS, Kondapavalru P, Krishna P, Chrismer JB, Raskin A, Hebel JR, et al. Evaluation of a portable low cost videophone system in the assessment of depressive symptoms and cognitive function in elderly medically ill veterans. J Nerv Ment Dis 2001 Jun;189(6):399-401. [doi: 10.1097/00005053-200106000-00009] [Medline: 11434642]

172. Miller L, Weissman M. Interpersonal psychotherapy delivered over the telephone to recurrent depressives. A pilot study. Depress Anxiety 2002;16(3):114-117. [doi: 10.1002/da.10047] [Medline: 12415535]

173. Miller CJ, McInnes DK, Stolzmann K, Bauer MS. Interest in use of technology for healthcare among veterans receiving treatment for mental health. Telemed J E Health 2016 Oct;22(10):847-854. [doi: 10.1089/tmj.2015.0190] [Medline: 26982279]

174. Mitchell JE, Crosby RD, Wonderlich SA, Crow S, Lancaster K, Simonich H, et al. A randomized trial comparing the efficacy of cognitive-behavioral therapy for bulimia nervosa delivered via telemedicine versus face-to-face. Behav Res Ther 2008 May;46(5):581-592 [FREE Full text] [doi: 10.1016/j.brat.2008.02.004] [Medline: 18374304]

175. Modai I, Jabarin M, Kurs R, Barak P, Hanan I, Kitain L. Cost effectiveness, safety, and satisfaction with video telepsychiatry versus face-to-face care in ambulatory settings. Telemed J E Health 2006 Oct;12(5):515-520. [doi: 10.1089/tmj.2006.12.515] [Medline: 17042703]

176. Mohr DC, Likosky W, Bertagnolli A, Goodkin DE, Van Der Wende J, Dwyer P, et al. Telephone-administered cognitive-behavioral therapy for the treatment of depressive symptoms in multiple sclerosis. J Consult Clin Psychol 2000 Apr;68(2):356-361. [doi: 10.1037//0022-006x.68.2.356] [Medline: 10780138]

177. Mohr DC, Hart SL, Julian L, Catledge C, Honos-Webb L, Vella L, et al. Telephone-administered psychotherapy for depression. Arch Gen Psychiatry 2005 Sep;62(9):1007-1014. [doi: 10.1001/archpsyc.62.9.1007] [Medline: 16143732]

178. Mohr DC, Hart SL, Marmar C. Telephone administered cognitive-behavioral therapy for the treatment of depression in a rural primary care clinic. Cogn Ther Res 2006 May 6;30(1):29-37. [doi: 10.1007/s10608-006-9006-0]

179. Mohr DC, Carmody T, Erickson L, Jin L, Leader J. Telephone-administered cognitive behavioral therapy for veterans served by community-based outpatient clinics. J Consult Clin Psychol 2011 Apr;79(2):261-265. [doi: 10.1037/a0022395] [Medline: 21299274]

180. Mohr DC, Duffecy J, Ho J, Kwasny M, Cai X, Burns MN, et al. A randomized controlled trial evaluating a manualized TeleCoaching protocol for improving adherence to a web-based intervention for the treatment of depression. PLoS One 2013;8(8):e70086 [FRE Full text] [doi: 10.1371/journal.pone.0070086] [Medline: 23990896] 
181. Moreno FA, Chong J, Dumbauld J, Humke M, Byreddy S. Use of standard Webcam and Internet equipment for telepsychiatry treatment of depression among underserved Hispanics. Psychiatr Serv 2012 Dec;63(12):1213-1217. [doi: 10.1176/appi.ps.201100274] [Medline: 23026854]

182. Morland LA, Pierce K, Wong MY. Telemedicine and coping skills groups for Pacific Island veterans with post-traumatic stress disorder: a pilot study. J Telemed Telecare 2004;10(5):286-289. [doi: 10.1258/1357633042026387] [Medline: 15494087]

183. Morland A, Greene CJ, Rosen CS, Foy D, Reilly P, Shore J, et al. Telemedicine for anger management therapy in a rural population of combat veterans with posttraumatic stress disorder: a randomized noninferiority trial. J Clin Psychiatry 2010 Jul;71(7):855-863. [doi: 10.4088/JCP.09m05604blu] [Medline: 20122374]

184. Morland LA, Hynes AK, Mackintosh MA, Resick PA, Chard KM. Group cognitive processing therapy delivered to veterans via telehealth: a pilot cohort. J Trauma Stress 2011 Aug;24(4):465-469. [doi: 10.1002/jts.20661] [Medline: 21793047]

185. Morland LA, Raab M, Mackintosh MA, Rosen CS, Dismuke CE, Greene CJ, et al. Telemedicine: a cost-reducing means of delivering psychotherapy to rural combat veterans with PTSD. Telemed J E Health 2013 Oct;19(10):754-759 [FREE Full text] [doi: 10.1089/tmj.2012.0298] [Medline: 23931729]

186. Morland LA, Mackintosh MA, Greene CJ, Rosen CS, Chard KM, Resick P, et al. Cognitive processing therapy for posttraumatic stress disorder delivered to rural veterans via telemental health: a randomized noninferiority clinical trial. $\mathrm{J}$ Clin Psychiatry 2014 May;75(5):470-476. [doi: 10.4088/JCP.13m08842] [Medline: 24922484]

187. Morland LA, Mackintosh MA, Rosen CS, Willis E, Resick P, Chard K, et al. Telemedicine versus in-person delivery of cognitive processing therapy for women with posttraumatic stress disorder: a randomized noninferiority tria. Depress Anxiety 2015 Nov;32(11):811-820. [doi: 10.1002/da.22397] [Medline: 26243685]

188. Cullum CM, Hynan LS, Grosch M, Parikh M, Weiner MF. Teleneuropsychology: evidence for video teleconference-based neuropsychological assessment. J Int Neuropsychol Soc 2014 Nov;20(10):1028-1033 [FREE Full text] [doi: 10.1017/S1355617714000873] [Medline: 25343269]

189. Nelson EL, Barnard M, Cain S. Treating childhood depression over videoconferencing. Telemed J E Health 2003;9(1):49-55. [doi: 10.1089/153056203763317648] [Medline: 12699607]

190. Neufeld J, Case R. Walk-in telemental health clinics improve access and efficiency: a 2-year follow-up analysis. Telemed J E Health 2013 Dec;19(12):938-941 [FREE Full text] [doi: 10.1089/tmj.2013.0076] [Medline: 24050609]

191. Newby JM, Mackenzie A, Williams AD, McIntyre K, Watts S, Wong N, et al. Internet cognitive behavioural therapy for mixed anxiety and depression: a randomized controlled trial and evidence of effectiveness in primary care. Psychol Med 2013 Dec;43(12):2635-2648. [doi: 10.1017/S0033291713000111] [Medline: 23419552]

192. Nieminen K, Berg I, Frankenstein K, Viita L, Larsson K, Persson U, et al. Internet-provided cognitive behaviour therapy of posttraumatic stress symptoms following childbirth-a randomized controlled trial. Cogn Behav Ther 2016 Jun;45(4):287-306. [doi: 10.1080/16506073.2016.1169626] [Medline: 27152849]

193. Niles BL, Klunk-Gillis J, Ryngala DJ, Silberbogen AK, Paysnick A, Wolf EJ. Comparing mindfulness and psychoeducation treatments for combat-related PTSD using a telehealth approach. Psychol Trauma Theory Res Pract Policy 2012;4(5):538-547. [doi: 10.1037/a0026161]

194. Nordgren LB, Hedman E, Etienne J, Bodin J, Kadowaki A, Eriksson S, et al. Effectiveness and cost-effectiveness of individually tailored Internet-delivered cognitive behavior therapy for anxiety disorders in a primary care population: a randomized controlled trial. Behav Res Ther 2014 Aug;59:1-11 [FREE Full text] [doi: 10.1016/j.brat.2014.05.007] [Medline: 24933451]

195. O'Reilly R, Bishop J, Maddox K, Hutchinson L, Fisman M, Takhar J. Is telepsychiatry equivalent to face-to-face psychiatry? Results from a randomized controlled equivalence trial. Psychiatr Serv 2007 Jun;58(6):836-843. [doi: 10.1176/ps.2007.58.6.836] [Medline: 17535945$]$

196. Ojserkis R, Morris B, McKay D. Pediatric obsessive-compulsive disorder. Clinical Case Studies 2013 Sep 25;13(1):68-79. [doi: $10.1177 / 1534650113504489]$

197. Olthuis JV, Watt MC, Mackinnon SP, Stewart SH. Telephone-delivered cognitive behavioral therapy for high anxiety sensitivity: a randomized controlled trial. J Consult Clin Psychol 2014 Dec;82(6):1005-1022. [doi: 10.1037/a0037027] [Medline: 24911423]

198. Paing WW, Weller RA, Dixon TA, Weller EB. Face-to-face versus telephone administration of the parent's version of the children's interview for psychiatric syndromes (P-ChIPS). Curr Psychiatry Rep 2010 Apr;12(2):122-126. [doi: 10.1007/s11920-010-0101-2] [Medline: 20425297]

199. Painter JT, Fortney JC, Austen MA, Pyne JM. Cost-effectiveness of telemedicine-based collaborative care for posttraumatic stress disorder. Psychiatr Serv 2017 Nov 01;68(11):1157-1163. [doi: 10.1176/appi.ps.201600485] [Medline: 28669290]

200. Paulsen AS, Crowe RR, Noyes R, Pfohl B. Reliability of the telephone interview in diagnosing anxiety disorders. Arch Gen Psychiatry 1988 Jan;45(1):62-63. [doi: 10.1001/archpsyc.1988.01800250076009] [Medline: 3337610]

201. Paxling B, Almlöv J, Dahlin M, Carlbring P, Breitholtz E, Eriksson T, et al. Guided internet-delivered cognitive behavior therapy for generalized anxiety disorder: a randomized controlled trial. Cogn Behav Ther 2011;40(3):159-173. [doi: 10.1080/16506073.2011.576699] [Medline: 21770848] 
202. Poon P, Hui E, Dai D, Kwok T, Woo J. Cognitive intervention for community-dwelling older persons with memory problems: telemedicine versus face-to-face treatment. Int J Geriatr Psychiatry 2005 Mar;20(3):285-286. [doi: 10.1002/gps.1282] [Medline: 15717335]

203. Price M, Gros DF. Examination of prior experience with telehealth and comfort with telehealth technology as a moderator of treatment response for PTSD and depression in veterans. Int J Psychiatry Med 2014;48(1):57-67. [doi: 10.2190/PM.48.1.e] [Medline: 25354926]

204. Pyne JM, Fortney JC, Tripathi SP, Maciejewski ML, Edlund MJ, Williams DK. Cost-effectiveness analysis of a rural telemedicine collaborative care intervention for depression. Arch Gen Psychiatry 2010 Aug;67(8):812-821. [doi: 10.1001/archgenpsychiatry.2010.82] [Medline: 20679589]

205. Rabinowitz T, Murphy KM, Amour JL, Ricci MA, Caputo MP, Newhouse PA. Benefits of a telepsychiatry consultation service for rural nursing home residents. Telemed J E Health 2010;16(1):34-40. [doi: 10.1089/tmj.2009.0088] [Medline: 20070161]

206. Ransom D, Heckman TG, Anderson T, Garske J, Holroyd K, Basta T. Telephone-delivered, interpersonal psychotherapy for HIV-infected rural persons with depression: a pilot trial. Psychiatr Serv 2008 Aug;59(8):871-877. [doi: 10.1176/ps.2008.59.8.871] [Medline: 18678684 ]

207. Revicki DA, Tohen M, Gyulai L, Thompson C, Pike S, Davis-Vogel A, et al. Telephone versus in-person clinical and health status assessment interviews in patients with bipolar disorder. Harv Rev Psychiatry 1997;5(2):75-81. [doi: 10.3109/10673229709034730] [Medline: 9385024]

208. Richter KP, Shireman TI, Ellerbeck EF, Cupertino AP, Catley D, Cox LS, et al. Comparative and cost effectiveness of telemedicine versus telephone counseling for smoking cessation. J Med Internet Res 2015 May 08;17(5):e113 [FREE Full text] [doi: 10.2196/jmir.3975] [Medline: 25956257]

209. Robinson E, Titov N, Andrews G, McIntyre K, Schwencke G, Solley K. Internet treatment for generalized anxiety disorder: a randomized controlled trial comparing clinician vs. technician assistance. PLoS One 2010 Jun 03;5(6):e10942 [FREE Full text] [doi: 10.1371/journal.pone.0010942] [Medline: 20532167]

210. Rohde P, Lewinsohn PM, Seeley JR. Comparability of telephone and face-to-face interviews in assessing axis I and II disorders. Am J Psychiatry 1997 Nov;154(11):1593-1598. [doi: 10.1176/ajp.154.11.1593] [Medline: 9356570]

211. Ruskin PE, Silver-Aylaian M, Kling MA, Reed SA, Bradham DD, Hebel JR, et al. Treatment outcomes in depression: comparison of remote treatment through telepsychiatry to in-person treatment. Am J Psychiatry 2004 Aug;161(8):1471-1476. [doi: 10.1176/appi.ajp.161.8.1471] [Medline: 15285975]

212. Russell TG, Gillespie N, Hartley N, Theodoros D, Hill A, Gray L. Exploring the predictors of home telehealth uptake by elderly Australian healthcare consumers. J Telemed Telecare 2015 Dec;21(8):485-489. [doi: 10.1177/1357633X15606264] [Medline: 26391512]

213. Salfi J, Ploeg J, Black ME. Seeking to understand telephone support for dementia caregivers. West J Nurs Res 2005 Oct;27(6):701-721. [doi: 10.1177/0193945905276882] [Medline: 16157943]

214. Schutte JL, McCue MP, Parmanto B, McGonigle J, Handen B, Lewis A, et al. Usability and reliability of a remotely administered adult autism assessment, the autism diagnostic observation schedule (ADOS) module 4. Telemed J E Health 2015 Mar;21(3):176-184 [FREE Full text] [doi: 10.1089/tmj.2014.0011] [Medline: 25569603]

215. Seidel RW, Kilgus MD. Agreement between telepsychiatry assessment and face-to-face assessment for Emergency Department psychiatry patients. J Telemed Telecare 2014 Mar;20(2):59-62. [doi: 10.1177/1357633X13519902] [Medline: 24414395]

216. Shealy KM, Davidson TM, Jones AM, Lopez CM, de Arellano MA. Delivering an evidence-based mental health treatment to underserved populations using telemedicine: the case of a trauma-affected adolescent in a rural setting. Cognit Behav Pract 2015 Aug;22(3):331-344. [doi: 10.1016/j.cbpra.2014.04.007]

217. Shore JH, Savin D, Orton H, Beals J, Manson SM. Diagnostic reliability of telepsychiatry in American Indian veterans. Am J Psychiatry 2007 Jan;164(1):115-118. [doi: 10.1176/ajp.2007.164.1.115] [Medline: 17202552]

218. Shore JH, Brooks E, Anderson H, Bair B, Dailey N, Kaufmann LJ, et al. Characteristics of telemental health service use by American Indian veterans. Psychiatr Serv 2012 Feb 01;63(2):179-181 [FREE Full text] [doi: 10.1176/appi.ps.201100098] [Medline: 22302338]

219. Shore P, Goranson A, Ward MF, Lu MW. Meeting veterans where they're @: a VA Home-Based Telemental Health (HBTMH) pilot program. Int J Psychiatry Med 2014;48(1):5-17. [doi: 10.2190/PM.48.1.b] [Medline: 25354923]

220. Simon GE, Revicki D, VonKorff M. Telephone assessment of depression severity. J Psychiatr Res 1993;27(3):247-252. [doi: 10.1016/0022-3956(93)90035-z] [Medline: 8295157]

221. Simon GE, Ludman EJ, Rutter CM. Incremental benefit and cost of telephone care management and telephone psychotherapy for depression in primary care. Arch Gen Psychiatry 2009 Oct;66(10):1081-1089. [doi: 10.1001/archgenpsychiatry.2009.123] [Medline: 19805698]

222. Simpson J, Doze S, Urness D, Hailey D, Jacobs P. Evaluation of a routine telepsychiatry service. J Telemed Telecare 2001;7(2):90-98. [doi: 10.1258/1357633011936219] [Medline: 11331046]

223. Simpson J, Doze S, Urness D, Hailey D, Jacobs P. Telepsychiatry as a routine service - the perspective of the patient. J Telemed Telecare 2001;7(3):155-160. [doi: 10.1258/1357633011936318] [Medline: 11346475] 
224. Simpson S, Bell L, Britton P, Mitchell D, Morrow E, Johnston A, et al. Does video therapy work? A single case series of bulimic disorders. Eur Eat Disorders Rev 2006 Jul;14(4):226-241. [doi: 10.1002/erv.686]

225. Singh SP, Arya D, Peters T. Accuracy of telepsychiatric assessment of new routine outpatient referrals. BMC Psychiatry 2007 Oct 05;7:55 [FREE Full text] [doi: 10.1186/1471-244X-7-55] [Medline: 17919329]

226. Smith AC, Stathis S, Randell A, Best D, Ryan V, Bergwever E, et al. A cost-minimization analysis of a telepaediatric mental health service for patients in rural and remote Queensland. J Telemed Telecare 2016 Dec 02;13(3_suppl):79-83. [doi: 10.1258/135763307783247239]

227. Smolenski DJ, Pruitt LD, Vuletic S, Luxton DD, Gahm G. Unobserved heterogeneity in response to treatment for depression through videoconference. Psychiatr Rehabil J 2017 Sep;40(3):303-308. [doi: 10.1037/prj0000273] [Medline: 28604014]

228. Spaniel F, Novak T, Motlova LB, Capkova J, Slovakova A, Trancik P, et al. Psychiatrist's adherence: a new factor in relapse prevention of schizophrenia. A randomized controlled study on relapse control through telemedicine system. J Psychiatr Ment Health Nurs 2015 Dec;22(10):811-820. [doi: 10.1111/jpm.12251] [Medline: 26176646]

229. Spaulding R, Belz N, DeLurgio S, Williams AR. Cost savings of telemedicine utilization for child psychiatry in a rural Kansas community. Telemed J E Health 2010 Oct;16(8):867-871. [doi: 10.1089/tmj.2010.0054] [Medline: 20925567]

230. Spence J, Titov N, Dear BF, Johnston L, Solley K, Lorian C, et al. Randomized controlled trial of internet-delivered cognitive behavioral therapy for posttraumatic stress disorder. Depress Anxiety 2011 Jul;28(7):541-550. [doi: 10.1002/da.20835] [Medline: 21721073]

231. Spence J, Titov N, Johnston L, Dear BF, Wootton B, Terides M, et al. Internet-delivered eye movement desensitization and reprocessing (iEMDR): an open trial. F1000Res 2013;2:79 [FREE Full text] [doi: 10.12688/f1000research.2-79.v2] [Medline: 24555047]

232. Spence J, Titov N, Johnston L, Jones MP, Dear BF, Solley K. Internet-based trauma-focused cognitive behavioural therapy for PTSD with and without exposure components: a randomised controlled trial. J Affect Disord 2014 Jun;162:73-80. [doi: 10.1016/j.jad.2014.03.009] [Medline: 24767009]

233. Staton-Tindall M, Havens JR, Webster JM, Leukefeld C. METelemedicine: a pilot study with rural alcohol users on community supervision. J Rural Health 2014;30(4):422-432 [FREE Full text] [doi: 10.1111/jrh.12076] [Medline: 24800699]

234. Stefan S, David D. Face-to-face counseling versus high definition holographic projection system. Efficacy and therapeutic alliance. A brief research report. J Cognit Behav Psychother 2013;13(2):299-307 [FREE Full text]

235. Steffen AM. Anger management for dementia caregivers: a preliminary study using video and telephone interventions. Behavior Therapy 2000;31(2):281-299. [doi: 10.1016/S0005-7894(00)80016-7]

236. Stevens A, Doidge N, Goldbloom D, Voore P, Farewell J. Pilot study of televideo psychiatric assessments in an underserviced community. Am J Psychiatry 1999 May;156(5):783-785. [doi: 10.1176/ajp.156.5.783] [Medline: 10327917]

237. Strachan M, Gros DF, Ruggiero KJ, Lejuez CW, Acierno R. An integrated approach to delivering exposure-based treatment for symptoms of PTSD and depression in OIF/OEF veterans: preliminary findings. Behav Ther 2012 Sep;43(3):560-569. [doi: 10.1016/j.beth.2011.03.003] [Medline: 22697444]

238. Stubbings DR, Rees CS, Roberts LD, Kane RT. Comparing in-person to videoconference-based cognitive behavioral therapy for mood and anxiety disorders: randomized controlled trial. J Med Internet Res 2013 Nov 19;15(11):e258 [FREE Full text] [doi: 10.2196/jmir.2564] [Medline: 24252663]

239. Swinson RP, Fergus KD, Cox BJ, Wickwire K. Efficacy of telephone-administered behavioral therapy for panic disorder with agoraphobia. Behav Res Ther 1995 May;33(4):465-469. [doi: 10.1016/0005-7967(94)00061-n] [Medline: 7755536]

240. Tan G, Teo I, Srivastava D, Smith D, Smith SL, Williams W, et al. Improving access to care for women veterans suffering from chronic pain and depression associated with trauma. Pain Med 2013 Jul;14(7):1010-1020. [doi: 10.1111/pme.12131] [Medline: 23659470]

241. Tang WK, Chiu H, Woo J, Hjelm M, Hui E. Telepsychiatry in psychogeriatric service: a pilot study. Int J Geriatr Psychiatry 2001 Jan;16(1):88-93. [doi: 10.1002/1099-1166(200101)16:1<88::aid-gps282>3.0.co;2-w] [Medline: 11180491]

242. Tarp K, Bojesen AB, Mejldal A, Nielsen AS. Effectiveness of optional videoconferencing-based treatment of alcohol use disorders: randomized controlled trial. JMIR Ment Health 2017 Sep 29;4(3):e38 [FREE Full text] [doi: 10.2196/mental.6713] [Medline: 28963093]

243. Taylor S, Thordarson DS, Spring T, Yeh AH, Corcoran KM, Eugster K, et al. Telephone-administered cognitive behavior therapy for obsessive-compulsive disorder. Cogn Behav Ther 2003;32(1):13-25. [doi: 10.1080/16506070310003639] [Medline: 16291531$]$

244. Théberge-Lapointe N, Marchand A, Langlois F, Gosselin P, Watts S. Efficacy of a cognitive-behavioural therapy administered by videoconference for generalized anxiety disorder. Eur Rev Appl Psychol 2015 Jan;65(1):9-17. [doi: 10.1016/j.erap.2014.10.001]

245. Thorp SR, Fidler J, Moreno L, Floto E, Agha Z. Lessons learned from studies of psychotherapy for posttraumatic stress disorder via video teleconferencing. Psychol Serv 2012 May;9(2):197-199. [doi: 10.1037/a0027057] [Medline: 22662733]

246. Titov N, Andrews G, Schwencke G, Drobny J, Einstein D. Shyness 1: distance treatment of social phobia over the internet. Aust N Z J Psychiatry 2008 Jul;42(7):585-594. [doi: 10.1080/00048670802119762] [Medline: 18612862]

247. Titov N, Andrews G, Schwencke G. Shyness 2: treating social phobia online: replication and extension. Aust N Z J Psychiatry 2008 Jul;42(7):595-605. [doi: 10.1080/00048670802119820] [Medline: 18612863 ] 
248. Titov N, Andrews G, Choi I, Schwencke G, Mahoney A. Shyness 3: randomized controlled trial of guided versus unguided internet-based CBT for social phobia. Aust N Z J Psychiatry 2008 Dec;42(12):1030-1040. [doi: 10.1080/00048670802512107] [Medline: 19016091]

249. Titov N, Andrews G, Robinson E, Schwencke G, Johnston L, Solley K, et al. Eclinician-assisted internet-based treatment is effective for generalized anxiety disorder: randomized controlled trial. Aust N Z J Psychiatry 2009 Jan 01;43(10):905-912. [doi: $10.1080 / 00048670903179269$ ]

250. Titov N, Andrews G, Johnston L, Robinson E, Spence J. Transdiagnostic internet treatment for anxiety disorders: a randomized controlled trial. Behav Res Ther 2010 Sep;48(9):890-899. [doi: 10.1016/j.brat.2010.05.014] [Medline: 20561606]

251. Titov N, Dear BF, Schwencke G, Andrews G, Johnston L, Craske MG, et al. Transdiagnostic internet treatment for anxiety and depression: a randomised controlled trial. Behav Res Ther 2011 Aug;49(8):441-452. [doi: 10.1016/j.brat.2011.03.007] [Medline: 21679925]

252. Tremont G, Davis JD, Bishop DS, Fortinsky RH. Telephone-delivered psychosocial intervention reduces burden in dementia caregivers. Dementia (London) 2008;7(4):503-520 [FREE Full text] [doi: 10.1177/1471301208096632] [Medline: 20228893]

253. Tse YJ, McCarty CA, Stoep AV, Myers KM. Teletherapy delivery of caregiver behavior training for children with attention-deficit hyperactivity disorder. Telemed J E Health 2015 Jun;21(6):451-458 [FREE Full text] [doi: 10.1089/tmj.2014.0132] [Medline: 25719609]

254. Tuerk PW, Yoder M, Ruggiero KJ, Gros DF, Acierno R. A pilot study of prolonged exposure therapy for posttraumatic stress disorder delivered via telehealth technology. J Trauma Stress 2010 Feb;23(1):116-123 [FREE Full text] [doi: 10.1002/jts.20494] [Medline: 20135675]

255. Tunstall N, Prince M, Mann A. Concurrent validity of a telephone-administered version of the Gospel Oak instrument (including the SHORT-CARE). Int J Geriat Psychiatry 1997 Oct;12(10):1035-1038. [doi:

10.1002/(SICI)1099-1166(199710)12:10<1035::AID-GPS688>3.0.CO;2-9]

256. Tutty, Spangler DL, Poppleton LE, Ludman EJ, Simon GE. Evaluating the effectiveness of cognitive-behavioral teletherapy in depressed adults. Behav Ther 2010 Jun;41(2):229-236. [doi: 10.1016/j.beth.2009.03.002] [Medline: 20412887]

257. Uebelacker LA, Marootian BA, Tigue P, Haggarty R, Primack JM, Miller IW. Telephone depression care management for Latino Medicaid health plan members: a pilot randomized controlled trial. J Nerv Ment Dis 2011 Sep;199(9):678-683. [doi: 10.1097/NMD.0b013e318229d100] [Medline: 21878782]

258. Vahia IV, Ng B, Camacho A, Cardenas V, Cherner M, Depp CA, et al. Telepsychiatry for neurocognitive testing in older rural Latino adults. Am J Geriatr Psychiatry 2015 Jul;23(7):666-670 [FREE Full text] [doi: 10.1016/j.jagp.2014.08.006] [Medline: 25708655]

259. van Ballegooijen W, Riper H, Klein B, Ebert DD, Kramer J, Meulenbeek P, et al. An internet-based guided self-help intervention for panic symptoms: randomized controlled trial. J Med Internet Res 2013 Jul 29;15(7):e154 [FREE Full text] [doi: 10.2196/jmir.2362] [Medline: 23896222]

260. van Bastelaar KM, Pouwer F, Cuijpers P, Riper H, Snoek FJ. Web-based depression treatment for type 1 and type 2 diabetic patients: a randomized, controlled trial. Diabetes Care 2011 Feb;34(2):320-325 [FREE Full text] [doi: 10.2337/dc10-1248] [Medline: 21216855]

261. Ward-King J, Cohen IL, Penning H, Holden JJ. Brief report: telephone administration of the autism diagnostic interview - revised: reliability and suitability for use in research. J Autism Dev Disord 2010 Oct;40(10):1285-1290. [doi: 10.1007/s10803-010-0987-x] [Medline: 20195733]

262. Watson CG, Anderson PE, Thomas D, Nyberg K. Comparability of telephone and face to face diagnostic interview schedules. J Nerv Ment Dis 1992 Aug;180(8):534-535. [doi: 10.1097/00005053-199208000-00010] [Medline: 1500937]

263. Wells KB, Burnam MA, Leake B, Robins LN. Agreement between face-to-face and telephone-administered versions of the depression section of the NIMH Diagnostic Interview Schedule. J Psychiatr Res 1988;22(3):207-220. [doi: 10.1016/0022-3956(88)90006-4] [Medline: 3225790]

264. Whealin JM, Seibert-Hatalsky LA, Howell JW, Tsai J. E-mental health preferences of Veterans with and without probable posttraumatic stress disorder. J Rehabil Res Dev 2015;52(6):725-738 [FREE Full text] [doi: 10.1682/JRRD.2014.04.0113] [Medline: 26562090]

265. Wierwille JL, Pukay-Martin ND, Chard KM, Klump MC. Effectiveness of PTSD telehealth treatment in a VA clinical sample. Psychol Serv 2016 Nov;13(4):373-379. [doi: 10.1037/ser0000106] [Medline: 27657798]

266. Wilz G, Schinköthe D, Soellner R. Goal attainment and treatment compliance in a cognitive-behavioral telephone intervention for family caregivers of persons with dementia. GeroPsych 2011 Sep;24(3):115-125. [doi: 10.1024/1662-9647/a000043]

267. Wims E, Titov N, Andrews G, Choi I. Clinician-assisted Internet-based treatment is effective for panic: a randomized controlled trial. Aust N Z J Psychiatry 2010 Jul;44(7):599-607. [doi: 10.3109/00048671003614171] [Medline: 20560847]

268. Winter L, Gitlin LN. Evaluation of a telephone-based support group intervention for female caregivers of community-dwelling individuals with dementia. Am J Alzheimers Dis Other Demen 2006;21(6):391-397 [FREE Full text] [doi: 10.1177/1533317506291371] [Medline: 17267370$]$

269. Wray LO, Shulan MD, Toseland RW, Freeman KE, Vásquez BE, Gao J. The effect of telephone support groups on costs of care for veterans with dementia. Gerontologist 2010 Oct;50(5):623-631. [doi: 10.1093/geront/gnq040] [Medline: 20507926] 
270. Yeung A, Johnson DP, Trinh NH, Weng WC, Kvedar J, Fava M. Feasibility and effectiveness of telepsychiatry services for chinese immigrants in a nursing home. Telemed J E Health 2009 May;15(4):336-341. [doi: 10.1089/tmj.2008.0138] [Medline: 19441951]

271. Yoshino A, Shigemura J, Kobayashi Y, Nomura S, Shishikura K, Den R, et al. Telepsychiatry: assessment of televideo psychiatric interview reliability with present- and next-generation internet infrastructures. Acta Psychiatr Scand 2001 Sep;104(3):223-226. [doi: 10.1034/j.1600-0447.2001.00236.x] [Medline: 11531660]

272. Yuen EK, Herbert JD, Forman EM, Goetter EM, Juarascio AS, Rabin S, et al. Acceptance based behavior therapy for social anxiety disorder through videoconferencing. J Anxiety Disord 2013 May;27(4):389-397. [doi: 10.1016/j.janxdis.2013.03.002] [Medline: 23764124]

273. Yuen EK, Gros DF, Price M, Zeigler S, Tuerk PW, Foa EB, et al. Randomized controlled trial of home-based telehealth versus in-person prolonged exposure for combat-related PSTD in Veterans: preliminary results. J Clin Psychol 2015 Jun;71(6):500-512. [doi: 10.1002/jclp.22168] [Medline: 25809565]

274. Zheng P, Gray MJ. Telehealth-based therapy connecting rural mandarin-speaking traumatized clients with a mandarin-speaking therapist. Clin Case Stud 2014 Apr 13;13(6):514-527. [doi: 10.1177/1534650114529182]

275. Zheng W, Nickasch M, Lander L, Wen S, Xiao M, Marshalek P, et al. Treatment outcome comparison between telepsychiatry and face-to-face buprenorphine medication-assisted treatment for opioid use disorder: a 2-year retrospective data analysis. J Addict Med 2017;11(2):138-144 [FREE Full text] [doi: 10.1097/ADM.0000000000000287] [Medline: 28107210]

276. Ziemba SJ, Bradley NS, Landry LA, Roth CH, Porter LS, Cuyler RN. Posttraumatic stress disorder treatment for Operation Enduring Freedom/Operation Iraqi Freedom combat veterans through a civilian community-based telemedicine network. Telemed J E Health 2014 May;20(5):446-450. [doi: 10.1089/tmj.2013.0312] [Medline: 24617961]

277. Aafjes-van Doorn K, Békés V, Prout TA. Grappling with our therapeutic relationship and professional self-doubt during COVID-19: will we use video therapy again? Counsel Psychol Q 2020 Jun 03:1-12. [doi: 10.1080/09515070.2020.1773404]

278. Guidelines for the practice of telepsychology. American Psychological Association. 2013. URL: https://www.apa.org/ practice/guidelines/telepsychology [accessed 2021-06-26]

279. Hoffman L, Wisniewski H, Hays R, Henson P, Vaidyam A, Hendel V, et al. Digital Opportunities for Outcomes in Recovery Services (DOORS). J Psychiatr Pract 2020;26(2):80-88. [doi: 10.1097/pra.0000000000000450]

280. Torous J, Myrick KJ, Rauseo-Ricupero N, Firth J. Digital mental health and COVID-19: using technology today to accelerate the curve on access and quality tomorrow. JMIR Ment Health 2020 Mar 26;7(3):e18848 [FREE Full text] [doi: 10.2196/18848] [Medline: 32213476]

281. Richardson S, Carroll C, Close J, Gordon A, O'Brien J, Quinn T, et al. Research with older people in a world with COVID-19: identification of current and future priorities, challenges and opportunities. Age Ageing 2020 Oct 23;49(6):901-906 [FREE Full text] [doi: 10.1093/ageing/afaa149] [Medline: 32584954]

282. Papatheodorou S. Umbrella reviews: what they are and why we need them. Eur J Epidemiol 2019 Jun 9;34(6):543-546. [doi: 10.1007/s10654-019-00505-6] [Medline: 30852716]

283. Mulder R, Singh AB, Hamilton A, Das P, Outhred T, Morris G, et al. The limitations of using randomised controlled trials as a basis for developing treatment guidelines. Evid Based Ment Health 2018 Feb 14;21(1):4-6. [doi: 10.1136/eb-2017-102701] [Medline: 28710065]

284. Johns B, Baltussen R, Hutubessy R. Programme costs in the economic evaluation of health interventions. Cost Eff Resour Alloc 2003 Feb 26;1(1):1 [FREE Full text] [doi: 10.1186/1478-7547-1-1] [Medline: 12773220]

\section{Abbreviations}

AMSTAR: Assessment of Multiple Systematic Reviews

ARC: Applied Research Collaboration

BAME: Black, Asian, and minority ethnic

NHS: National Health Service

NIHR: National Institute for Health Research

PRISMA: Preferred Reporting Items for Systematic Reviews and Meta-Analyses

PTSD: posttraumatic stress disorder 
Edited by R Kukafka; submitted 14.12.20; peer-reviewed by A Khoja, L Le; comments to author 12.03.21; revised version received 30.03.21; accepted 30.04.21; published 20.07.21

Please cite as:

Barnett P, Goulding L, Casetta C, Jordan H, Sheridan-Rains L, Steare T, Williams J, Wood L, Gaughran F, Johnson S

Implementation of Telemental Health Services Before COVID-19: Rapid Umbrella Review of Systematic Reviews

$J$ Med Internet Res 2021;23(7):e26492

URL: https://www.jmir.org/2021/7/e26492

doi: $10.2196 / 26492$

PMID: $\underline{34061758}$

(CPhoebe Barnett, Lucy Goulding, Cecilia Casetta, Harriet Jordan, Luke Sheridan-Rains, Thomas Steare, Julie Williams, Lisa Wood, Fiona Gaughran, Sonia Johnson. Originally published in the Journal of Medical Internet Research (https://www.jmir.org), 20.07.2021. This is an open-access article distributed under the terms of the Creative Commons Attribution License (https://creativecommons.org/licenses/by/4.0/), which permits unrestricted use, distribution, and reproduction in any medium, provided the original work, first published in the Journal of Medical Internet Research, is properly cited. The complete bibliographic information, a link to the original publication on https://www.jmir.org/, as well as this copyright and license information must be included. 